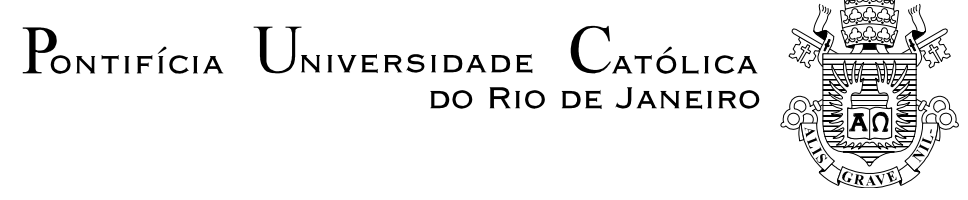

Marcelo Tangerini

Implantação de um processo de gestão de estoques em unidades marítimas de armazenagem e escoamento de petróleo

Dissertação de Mestrado (Opção profissional)

Dissertação apresentada como requisito parcial para obtenção do título de Mestre pelo Programa de PósGraduação em Engenharia de Produção da PUC-Rio.

Orientador: Prof. Antonio Fernando de Castro Vieira

Rio de Janeiro Dezembro de 2012 


$$
\text { Pontifícia Universidade } \text { Católica }_{\text {Do Rio de JANEIro }}
$$

Marcelo Tangerini

\section{Implantação de um processo de gestão de estoques em unidades marítimas de armazenagem e escoamento de}

petróleo

Dissertação apresentada como requisito parcial para obtenção do título de Mestre pelo Programa de PósGraduação em Engenharia de Produção da PUC-Rio. Aprovada pela Comissão Examinadora abaixo assinada.

Prof. Antonio Fernando de Castro Vieira

Orientador e Presidente

Departamento de Engenharia Industrial - PUC-Rio

Prof. Eugenio Kahn Epprecht

Departamento de Engenharia Industrial - PUC-Rio

Prof. Marcelo Maciel Monteiro

Petróleo Brasileiro - Rio de Janeiro - Matriz

Prof. José Eugênio Leal

Coordenador Setorial do Centro Técnico Científico - PUC-Rio

Rio de Janeiro, 20 de dezembro de 2012. 
Todos os direitos reservados. É proibida a reprodução total ou parcial do trabalho sem autorização da universidade, do autor e do orientador.

\section{Marcelo Tangerini}

Graduou-se em Engenharia de Produção pela Universidade Federal Fluminense (UFF) em 2002. Trabalhou na área de Planejamento e Qualidade do Centro de Distribuição das Lojas Americanas, ligado ao Departamento de Logística, entre 2000 e 2004. É funcionário da Petrobras desde 2004, atuando desde 2006 na área de Qualidade e Estoque de Produtos, sob a diretoria de Exploração e Produção.

Ficha Catalográfica

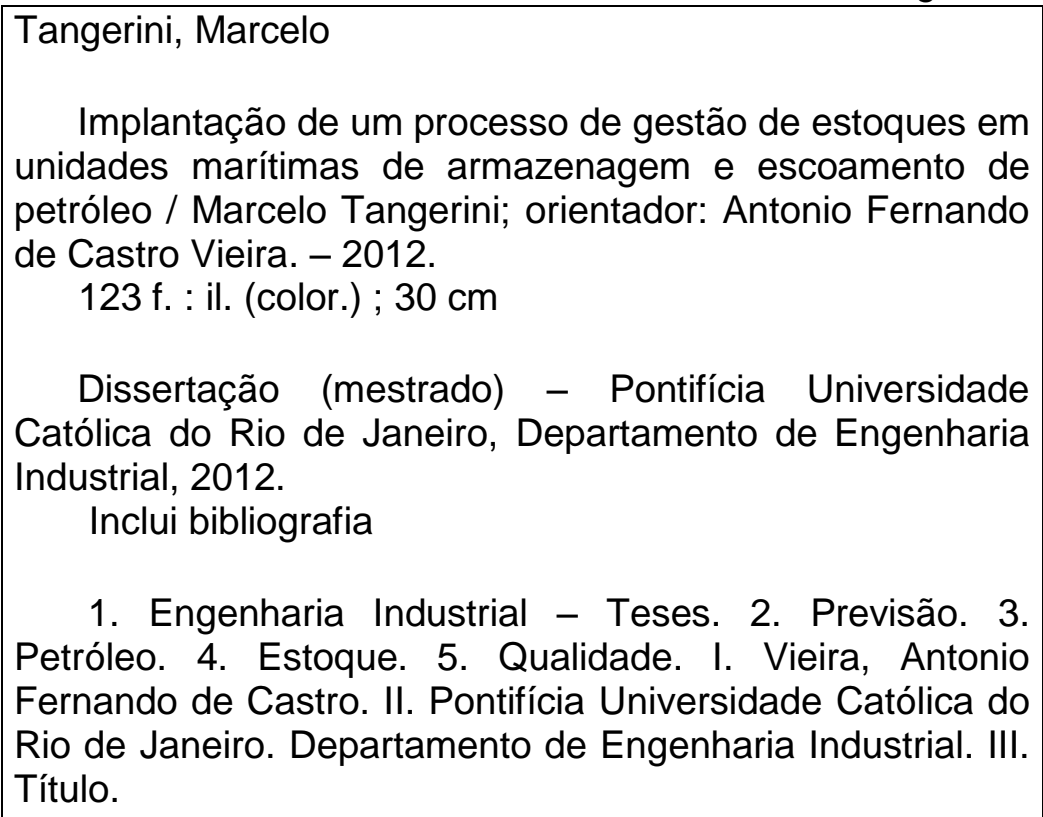

1. Engenharia Industrial - Teses. 2. Previsão. 3. Petróleo. 4. Estoque. 5. Qualidade. I. Vieira, Antonio Fernando de Castro. II. Pontifícia Universidade Católica do Rio de Janeiro. Departamento de Engenharia Industrial. III. Título. 
Dedico esta conquista aos meus pais, Nirson e Aliete, pela educação, atenção e carinho, além do incentivo e apoio em todas as minhas decisões.

Sem vocês nada disso seria possível. 


\section{Agradecimentos}

À Deus, por estar presente em todos os momentos da minha vida, por me amparar nos momentos difíceis, me dar força para superar as dificuldades, mostrar o caminho nas horas incertas e me suprir em todas as minhas necessidades.

À Petrobras, empresa em que trabalho, que me proporcionou este curso como parte do meu desenvolvimento profissional.

Ao Francisco Ferreira da Costa, meu amigo e gerente, que, além de me indicar e me incentivar a fazer este curso pela empresa, deu todo o apoio para que este projeto se tornasse uma realidade.

A todos os meus colegas de trabalho, que participaram diretamente deste projeto e me ajudaram em todos os momentos, em especial ao engenheiro Antonio Orestes de Salvo Castro, por ser o meu orientador dentro da empresa. Sua participação foi fundamental para a realização deste trabalho.

À minha namorada, Renata Pinheiro Felipe, por todo amor, apoio e compreensão.

À minha família, pelo carinho, paciência e incentivo.

Aos meus colegas da PUC-Rio, pela troca de conhecimentos.

Aos professores que participaram da Comissão Examinadora.

A todos os meus amigos e familiares que, de uma forma ou de outra, me estimularam ou me ajudaram. 


\section{Resumo}

Tangerini, Marcelo; Vieira, Antonio Fernando de Castro. Implantação de um Processo de Gestão de Estoques em Unidades Marítimas de Armazenagem e Escoamento de Petróleo. Rio de Janeiro, 2012. 123p. Dissertação de Mestrado - Departamento de Engenharia Industrial, Pontifícia Universidade Católica do Rio de Janeiro.

As perspectivas de aumento da produção nacional de petróleo, após as recentes descobertas do pólo pré-sal, e o conseqüente aumento do número de pontos de escoamento via modal marítimo, vêm tornando os sistemas logísticos de suprimento das refinarias nacionais e da exportação dos volumes excedentes cada vez mais complexos. Além destes aspectos, há que se considerar a curva de produção de água, que cresce ao longo da vida útil de um reservatório de petróleo, influenciando na sua qualidade. Diante deste contexto, é notória a necessidade de se criar um processo de gestão de estoques, que seja capaz de definir os seus níveis ideais, prever os estoques e a qualidade do óleo armazenado, bem como sugerir o tamanho dos lotes para a sua retirada, para suportar o processo de tomada de decisão quanto à programação de navios para o escoamento da produção, de modo a garantir a sua continuidade, atendendo às especificações de qualidade requeridas, além de considerar a análise do trade-off entre os custos do transporte marítimo e o custo de oportunidade do óleo armazenado. Este trabalho apresenta o desenvolvimento e o início da implantação de um processo de gestão de estoques na área de Exploração e Produção de uma empresa integrada do segmento de petróleo e gás, onde se observou a necessidade do desenvolvimento de um simulador para prever a qualidade e o estoque em unidades marítimas de escoamento de petróleo. Inicialmente, a maioria das variáveis de entrada no modelo será determinística, porém, recomenda-se que, no futuro, sejam incorporadas as demais aleatoriedades, de modo que o simulador seja capaz de capturar a natureza estocástica do processo e sua complexidade.

\section{Palavras-chave}

Previsão; petróleo; estoque; qualidade. 


\section{Abstract}

Tangerini, Marcelo; Vieira, Antonio Fernando de Castro (Advisor). Implementation of a Inventory Management Process in Offshore Units of Production and Storage of Oil. Rio de Janeiro, 2012. 123p. MSc. Dissertation - Departamento de Engenharia Industrial, Pontifícia Universidade Católica do Rio de Janeiro.

The perspectives in the rise of the national production of petrol, after the recent discoveries of the pre - salt pole and consequently the rise in the number of points of drainage via maritime modal have been turning the logistics systems of supplements of the national refineries and the exports of the exceeding volumes more and more complex. Further more one must consider the curve in the production of water that rises along with the production in a living reservoir of petrol influencing in its quality. Taking this context into consideration it is notorious that it is needed to create a process of managing stocks that is able to define its ideal levels, forecast the stocks and the quality of storied oil, as well as suggesting its withdrawal to support the process of decision making related to the programming of ships for the flow of production so as to guaranty its continuity regarding the specifications of quality required besides considering the analysis of its trade off between the costs of maritime transport and the cost of the opportunity of stored oil. This paper presents the developing and the beginning of the implementation of a managing process of stock in the area of upstream of an integrated company in the gas and petrol segment where there was the necessity of development of a simulator to preview the quality and the stock in maritime unities in the flow of petrol. To begin with most of the variables of entry in the model will be determining but it is recommended that in the future all the other variables are incorporated so as the simulator is able to capture the stockiest nature of the process and its complexity.

\section{Keywords}

Prediction; oil; inventory; quality. 


\section{Sumário}

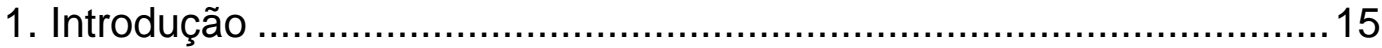

1.1. Objetivos e Delimitação da Pesquisa ............................................16

1.2. Estrutura da Dissertação ............................................................ 17

2. Revisão da Literatura Acadêmica....................................................19

2.1. Gestão de Estoques ...................................................................19

2.1.1. Modelos de Previsão da Demanda Aplicados na Gestão

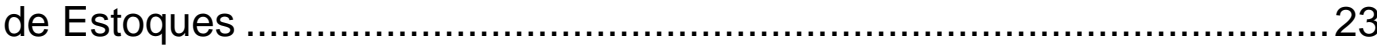

3. Diagnóstico da Situação Atual e Necessidades de Melhoria.................36

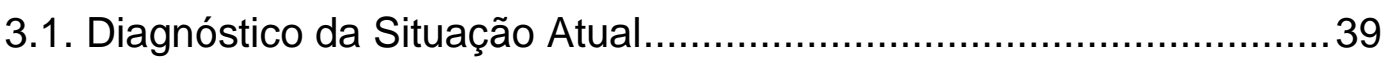

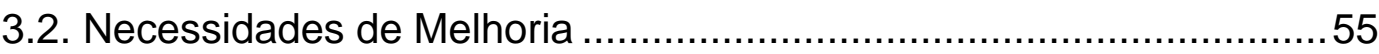

4. Desenvolvimento do Processo de Gestão de Estoques das Unidades Marítimas de Armazenagem e Escoamento de Petróleo ...........................60

4.1. Padrão de Estruturação do Processo .................................................62

4.2. Desenvolvimento do Processo de Gestão de Estoques.....................64

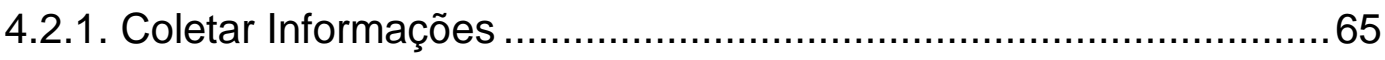

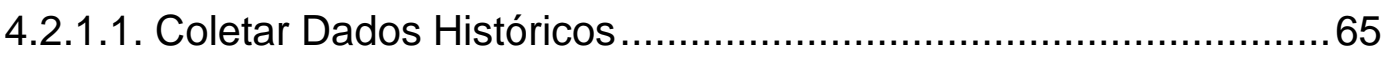

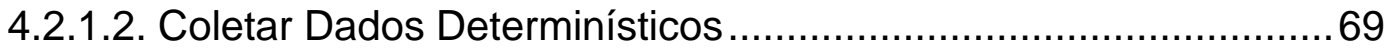

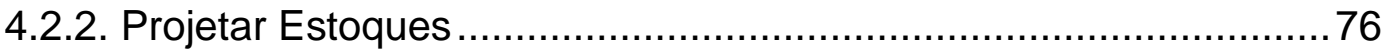

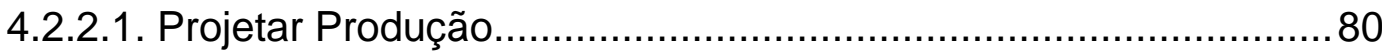

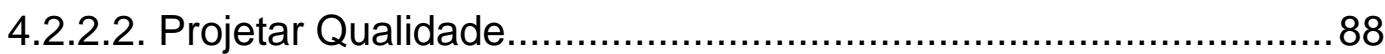

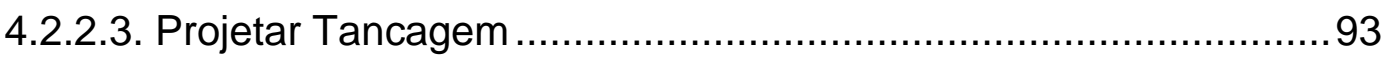

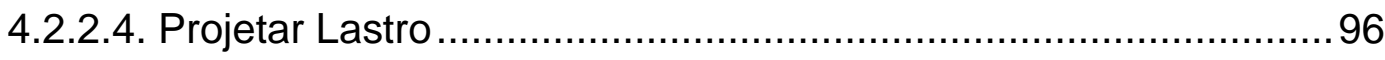

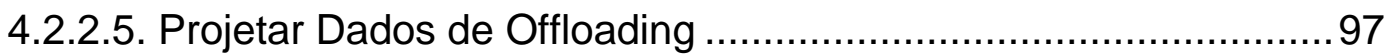

4.2.2.6. Analisar Cenários e Selecionar Melhor Projeção ....................... 100

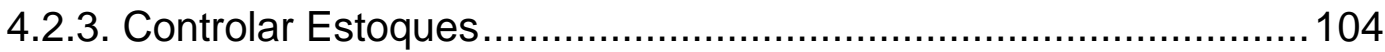

4.2.4. Analisar Desempenho e Propor Melhorias .................................109 
4.2.4.1. Calcular Indicadores..........................................................110

4.2.4.2. Analisar Indicadores e Propor Melhorias .................................116

5. Conclusões e Oportunidades de Pesquisas Futuras .........................118

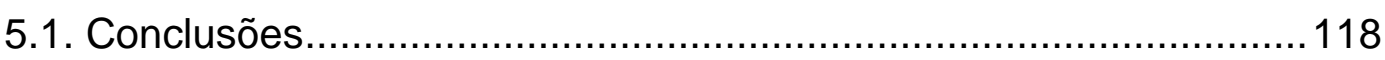

5.2. Oportunidades de Pesquisas Futuras .........................................120

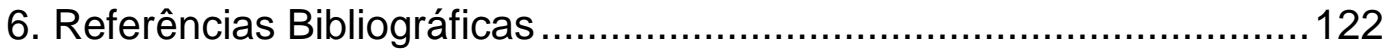




\section{Lista de Figuras}

Figura 1 - Estrutura de um Sistema de Previsão

25

Figura 2 - Modelo Conceitual das Variáveis que influenciam os níveis de estoque nos $F(P)$ SOS

Figura 3 - Padrão BPM de Mapeamento de Processo

Figura 4 - Padrão BPM de Mapeamento de Processo

(Legenda de fluxos)

Figura 5 - Macro-Processos e Processos de Gestão de Estoques

Figura 6 - Detalhamento do Macroprocesso "Coletar Informações" ........64

Figura 7 - Fluxograma do processo "Coletar Dados Históricos"

Figura 8 - Tela de Consulta do Boletim PRP no sistema WEBEP com dados fictícios.

Figura 9 - Fluxograma do processo "Coletar Dados Determinísticos" .....75

Figura 10 - Esquemático da Arquitetura Básica do Sistema de Gestão

de Estoque de Petróleo

Figura 11 - Tela Inicial do Sistema de Gestão de Estoque de

Petróleo (SIGEP)

Figura 12 - Detalhamento do Macroprocesso "Projetar Estoques" ..........80

Figura 13 - Fluxograma do processo Projetar Produção 80

Figura 14 - Tela de Entrada de Dados de Produção do Sistema de

Gestão de Estoque de Petróleo 82

Figura 15 - Fluxograma do processo Projetar Qualidade 88

Figura 16 - Tela de Entrada de Dados de Qualidade do Sistema de Gestão de Estoque de Petróleo 90

Figura 17 - Diagrama Esquemático (simplificado) da Produção de Petróleo 91

Figura 18 - Fluxograma do processo Projetar Tancagem .93

Figura 19 - Tela de Entrada de Dados de Tancagem do Sistema de

Gestão de Estoque de Petróleo .95

Figura 20 - Fluxograma do processo Projetar Lastro 96 
Figura 21 - Tela de Entrada de Dados de Lastro do Sistema de Gestão

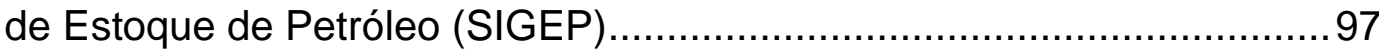

Figura 22 - Fluxograma do processo Projetar Dados de Offloading ........98

Figura 23 - Tela de Entrada de Dados de Offloading do Sistema de Gestão de Estoque de Petróleo 99

Figura 24 - Fluxograma do processo Analisar Cenários e Selecionar

Melhor Projeção 101

Figura 25 - Detalhamento do Macroprocesso Controlar Estoques 105

Figura 26 - Fluxograma do processo Controlar Qualidade e Níveis de Estoque 106

Figura 27 - Exemplo (fictício) de consulta do relatório Situação

Geral das Plataformas 108

Figura 28 - Exemplo (fictício) de consulta do relatório de offloading .....109 Figura 29 - Detalhamento do Macroprocesso Analisar Desempenho e Propor Melhorias 110

Figura 30 - Fluxograma do processo Calcular Indicadores 111

Figura 31 - Fluxograma do processo Analisar Indicadores e Propor Melhorias 


\section{Lista de Gráficos}

Gráfico 1 - Demanda x Previsão com Média Móvel................................28

Gráfico 2 - Demanda x Previsão com Amortecimento Exponencial ........31

Gráfico 3 - Demanda e Linha de Regressão .........................................34

Gráfico 4 - Demanda x Previsão com Amortecimento Exponencial

Duplo.

Gráfico 5 - Previsão com Amortecimento Exponencial

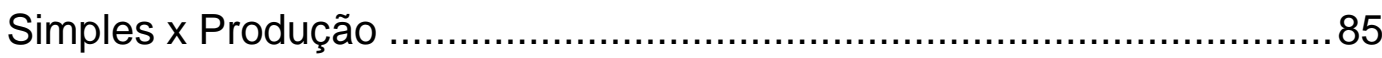

Gráfico 6 - Produção com Linha de Tendência ....................................... 86

Gráfico 7 - Previsão com Amortecimento Exponencial

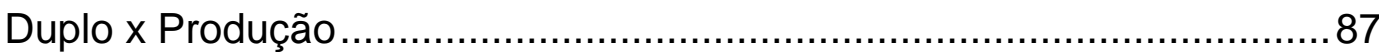

Gráfico 8 - Exemplo Fictício de Projeção de Estoques...........................102

Gráfico 9 - Exemplo (fictício) de acompanhamento do BSW produzido

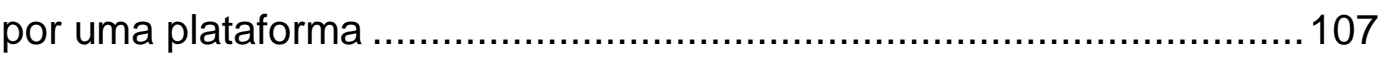

Gráfico 10 - Exemplo (fictício) do índice de tratamento de óleo ............112

Gráfico 11 - Exemplo (fictício) do indicador distribuição (\%)

da qualidade do óleo em estoque

Gráfico 12 - Exemplo (fictício) do indicador fator de utilização

da capacidade operacional

Gráfico 13 - Exemplo (fictício) do indicador duração média

de offloading.....

Gráfico 14 - Exemplo (fictício) do índice de previsão de

óleo disponível 


\section{Lista de Tabelas}

Tabela 1 - Crescimento da Produção e do número de Plataformas de Armazenagem e Escoamento Marítimo de Petróleo

Tabela 2 - Conflitos Interdepartamentais em Relação aos Níveis de Estoques

Tabela 3 - Simulação da Previsão de Demanda com uma Média Móvel de 10 semanas. 28

Tabela 4 - Simulação da Previsão com Amortecimento Exponencial......30

Tabela 5 - Demanda Mensal de um produto químico (toneladas) ............33

Tabela 6 - Demanda Mensal de um produto químico (toneladas) ............34

Tabela 7 - Causas e responsabilidades pelo não atendimento do IAPA .46

Tabela 8 - Quadro Resumo do Diagnóstico da Situação Atual das

Variáveis sob gestão do E\&P 56

Tabela 9 - Exemplo de Estoque de Óleo, em função da Qualidade, e de Água 66

Tabela 10 - Exemplo Fictício de Previsão da Média Mensal da

Produção Diária. 70

Tabela 11 - Exemplo Fictício de Previsão de Paradas Programadas......70

Tabela 12 - Exemplo Fictício de Previsão de Novos Projetos -

Entrada de Poços. .70

Tabela 13 - Exemplo de Dados Determinísticos de Qualidade 71

Tabela 14 - Exemplo de Dados Determinísticos de Tancagem. .72

Tabela 15 - Exemplo de Dados Determinísticos de Lastro .72

Tabela 16 - Exemplo de Dados Determinísticos de Offloading -

Capacidade de Bombeio

Tabela 17 - Exemplo de Dados Determinísticos de Offloading Restrições das Operações

Tabela 18 - Exemplo de Dados Determinísticos de Offloading -

Offloadings Programados .74

Tabela 19 - Planilha Dados Determinísticos (dados fictícios) 76 
Tabela 20 - Exemplo (fictício) de Projeção de Estoques considerando

Eventos Determinísticos de Produção

Tabela 21 - Dados Históricos (fictícios) da Produção Bruta -

Modelo Constante

Tabela 22 - Simulação da Previsão de Produção e do Erro Médio

Quadrático (EMQ) - Amortecimento Exponencial Simples

Tabela 23 - Dados Históricos (fictícios) da Produção Bruta -

Modelo Linear.

Tabela 24 - Simulação da Previsão de Produção e do Erro Médio

Quadrático (EMQ) - Amortecimento Exponencial Duplo

Tabela 25 - Exemplo (dados fictícios) de Projeção de Distribuição da

Produção de Petróleo por faxa de qualidade considerando Eventos

Determinísticos

Tabela 26 - Exemplo de Cálculo de Capacidade Operacional considerando Eventos Determinísticos

Tabela 27 - Exemplo Fictício de Projeção de Estoques

Tabela 28 - Exemplo (dados fictícios) de Análise Comparativa dos

Custos Totais de Diferentes Cenários de Projeção. 


\section{Introdução}

Devido ao crescimento da produção e do número de plataformas de armazenagem e escoamento marítimo de petróleo até o dado momento, e com a estimativa de crescimento numa taxa ainda maior até o ano de 2020, devido às recentes descobertas no pólo do pré-sal, conforme apresentado na Tabela 1, tornase necessária a melhoria do fluxo de informações entre o segmento de Exploração e Produção e o segmento de Abastecimento-Logística, para permitir uma melhor programação de navios, de modo a minimizar o risco de parada ou redução da produção de uma plataforma por falta de escoamento; minimizar o risco de entrega de óleo fora da especificação (considerado produto semi-acabado) requerida pelas refinarias ou para exportação; reduzir os custos de sobreestadia, que corresponde ao tempo que excede a estadia de um navio para uma operação normal de transferência de petróleo; e para reduzir os custos com praça morta, que corresponde ao espaço do navio não utilizado para transporte de produto. Estes eventos indesejados podem ocorrer devido a problemas operacionais não previstos ou devido à falta de um processo estruturado de previsão do estoque e da qualidade do óleo ao longo do tempo, a fim de permitir um melhor planejamento destas retiradas.

Tabela 1 - Crescimento da Produção e do número de Plataformas de Armazenagem e Escoamento Marítimo de Petróleo

\begin{tabular}{|c|c|c|c|c|c|}
\cline { 2 - 6 } \multicolumn{1}{c|}{} & 2003 & 2011 & $\begin{array}{c}\text { Variação } \\
(2003 \text { a 2011) }\end{array}$ & 2020 & $\begin{array}{c}\text { Variação } \\
(2003 \text { a 2020) }\end{array}$ \\
\hline $\begin{array}{c}\text { Número de } \\
\text { plataformas }\end{array}$ & 12 & 35 & $192 \%$ & 79 & $558 \%$ \\
\hline $\begin{array}{c}\text { Produção } \\
(1.000 \text { bpd })\end{array}$ & 1.540 & 2.022 & $31 \%$ & 4.200 & $173 \%$ \\
\hline
\end{tabular}

Fonte: O autor, (2012). 
1.1

Objetivos e Delimitação da Pesquisa

Este trabalho tem por objetivo apresentar o desenvolvimento e o início da implantação de um processo de gestão de estoques, que seja capaz de determinar os níveis ideais de estoque de cada plataforma, projetar a qualidade e o estoque de óleo disponível para cada uma delas, bem como sugerir as datas e os lotes para a sua retirada, com base diária (com um horizonte mínimo de dois meses), para suportar o processo de tomada de decisão quanto à programação de navios para o escoamento da produção. Este processo também deverá analisar o estoque imobilizado de óleo armazenado nas plataformas, sendo monitorado de maneira a não impactar o resultado empresarial da companhia. Os custos de capital do óleo armazenado e do transporte marítimo para o seu escoamento devem ser gerenciados e ações devem ser tomadas para a sua redução. Deverão ser definidos e medidos indicadores de desempenho, com o objetivo de analisar os resultados e propor ações de melhoria para os processos que influenciam na variabilidade dos estoques.

A implantação do processo trará ganhos não apenas à atividade de programação de navios para a retirada de petróleo das plataformas, como também dará maior robustez ao planejamento de médio prazo para alocação de petróleo nas refinarias; decisões de importação e exportação; e o planejamento de médio prazo da frota de navios aliviadores.

Os direcionadores para os níveis de estoque das plataformas são:

- minimizar risco de redução ou parada de produção por falta de escoamento da produção, de modo a garantir a sua continuidade operacional;

- atender às especificações de qualidade requeridas pelos clientes internos (refinarias nacionais próprias) e externos (exportação);

- considerar a análise do trade-off entre os custos do transporte marítimo e o custo de oportunidade do óleo armazenado.

O objetivo secundário do trabalho é o desenvolvimento de uma ferramenta de apoio à decisão para auxiliar na previsão dos volumes de óleo - com sua 
respectiva qualidade - e de água estocados nas unidades marítimas de armazenagem e escoamento de petróleo e na determinação dos lotes de retirada, utilizando um tratamento estocástico, levando em conta as incertezas associadas aos processos de produção, processamento, armazenagem e transferência e sua natureza aleatória, e que seja possível de ser implantada de forma sistemática em todos os FPSOs (Floating Production Storage and Offloading - unidade flutuante de produção, armazenagem e transferência de petróleo). Esta ferramenta subsidiará os processos de programação de navios para escoamento do óleo produzido pelas plataformas, planejamento das cargas de importação e exportação de petróleo, o monitoramento das variáveis de processamento que afetam a qualidade do óleo, o acompanhamento do plano de manutenção e inspeção dos tanques de armazenagem e o acompanhamento da disponibilidade das estações de offloading (transferência) dos FPSOS. Para tal, deverá produzir uma curva com previsão de estoque e qualidade do óleo de cada $\mathrm{F}(\mathrm{P}) \mathrm{SO}$ para o período de dois meses, atualizada mensalmente, e que poderá ter suas variáveis de entrada modificadas para simular diversos cenários de eventos aleatórios.

A pesquisa está delimitada às unidades marítimas de armazenagem e escoamento de petróleo (FPSOs e FSOs) da Petrobras, localizados na costa brasileira, e que representam em torno de $85 \%$ da produção nacional. O gás e outros derivados do petróleo não fazem parte do escopo desta dissertação, bem como os sistemas de escoamento via modais dutoviário ou rodoviário também não.

\section{2}

\section{Estrutura da Dissertação}

Esta dissertação reporta, em seu capítulo 2, uma revisão da literatura acadêmica a respeito do processo de gestão de estoques e os demais capítulos são descritos resumidamente abaixo:

- O capítulo 3 apresenta um breve resumo do processo de planejamento do escoamento da produção e dos estoques de petróleo da companhia, um diagnóstico da situação atual dos processos da área de Exploração e Produção 
que influenciam os níveis de estoque nas plataformas, e as necessidades de melhoria;

- O capítulo 4 é dedicado ao desenvolvimento do processo de gestão de estoques e dos fluxogramas das suas atividades;

- $\quad$ O capítulo 5 apresenta as conclusões e as oportunidades de pesquisas futuras. 
2

\section{Revisão da Literatura Acadêmica}

\section{1}

\section{Gestão de Estoques}

Num ambiente extremamente competitivo e cada vez mais aberto comercialmente devido à globalização, os administradores têm buscado implantar sistemas mais eficientes de gestão, que conduzam as organizações ao atendimento de seus objetivos estratégicos. Dentre as iniciativas mais comumente utilizadas neste ambiente destaca-se a busca por redução dos custos de estoques e de modelos de gestão que sejam mais eficientes.

A impossibilidade de sincronização perfeita entre a demanda e o fornecimento obriga as organizações a manterem estoques para atender a demanda. Suas finalidades podem ser listadas como: melhorar o nível de serviço; incentivar economias na produção; permitir economias de escala nas compras e no transporte; proteger a empresa quanto a incertezas na demanda ou no tempo de suprimento; proteção contra contingências como greves ou incêndios (BALLOU, 1993).

Bertaglia (2005) externa que "a formação do estoque está relacionada ao desequilíbrio existente entre a demanda e o fornecimento".

Por ser impossível prever rigorosamente a demanda dos clientes, faz-se necessário o estoque na organização, pois é o meio que garante a disponibilidade da mercadoria no momento da sua requisição.

Na concepção de Pozo (2008), uma das mais importantes funções da administração de materiais está relacionada com o controle de níveis de estoques.

De acordo com Bertaglia (2005)

[...] os estoques desempenham papel importante e possuem funções distintas relacionadas às demandas de mercado, às características do produto e sua movimentação e à interferência da situação econômica. 
Pode-se perceber claramente o papel desempenhado pelos estoques nas organizações, variando de acordo com a área de atuação de cada organização, características de cada negócio e produto, considerando-se também o impacto de seus valores e custos. Com isto, faz-se necessário uma gestão eficaz dos estoques, agregando assim vantagem competitiva organizacional.

Ching (2006, p. 33) destaca que, de maneira geral, há três tipos básicos de estoque existentes em uma indústria de manufatura:

- Matéria-prima: requer processamento para ser transformada posteriormente em um produto acabado. Sua utilização é proporcional ao volume de produção;

- Produtos semi-acabados: são materiais que estão em diferentes etapas do processo de fabricação. Abrange todos os materiais em que a empresa executou alguma espécie de processamento ou transformação, mas que ainda não se encontram na forma acabada para a venda;

- Produtos acabados: são os produtos finais de fabricação, prontos para a venda.

De acordo com Slack et al. (1997, p. 423), o conceito de gestão de estoques originou-se na função de compras em empresas que compreenderam a importância de integrar o fluxo de materiais às suas funções de suporte, tanto por meio do negócio, como por meio do fornecimento aos clientes internos. Isso inclui a função de compras, de acompanhamento, gestão da armazenagem, planejamento e controle da produção e gestão da distribuição física.

Ching (2006, p. 33) entende por gestão de estoques o planejamento do estoque, seu controle e sua retroalimentação sobre o planejamento. O planejamento consiste na determinação dos valores que o estoque terá com o decorrer do tempo, bem como na determinação das datas de entrada e saída dos materiais em estoque e na determinação dos pontos de pedido de material. $\mathrm{O}$ controle consiste na determinação dos dados reais, correspondentes aos planejados mencionados. A retroalimentação é a comparação dos dados de controle com os dados do planejamento, a fim de constatar seus desvios e determinar suas causas. Quando for o caso, a empresa deve corrigir o plano para torná-lo mais realista, fazendo com que o planejamento e o controle sejam cada vez mais coincidentes.

Para Wanke (2011) a importância da gestão de estoques para a logística e para o gerenciamento da cadeia de suprimentos tem se tornado cada vez mais 
evidente e quando se trata de ambientes complexos, como as cadeias de suprimento compostas por diversos estágios, não é um processo trivial, podendo acarretar impactos significativos nos níveis de serviço ao cliente e nos custos totais.

A gestão de estoques busca conciliar da melhor maneira possível os objetivos diferentes de cada departamento de negócios sem prejudicar a operacionalidade da empresa (CONORADO, 2001). Neste sentido, Messias (1993) complementa que comumente existem conflitos quanto aos níveis de estoques sob a ótica dos departamentos de finanças, vendas, produção e compra. Cada segmento estabelece preceitos diferentes de acordo com seus objetivos.

Através da Tabela 2, são apresentados esses conflitos de acordo com cada departamento levando em consideração níveis elevados de estoques.

Tabela 2 - Conflitos Interdepartamentais em Relação aos Níveis de Estoques

\begin{tabular}{|c|c|c|}
\hline $\begin{array}{l}\text { Matéria-Prima } \\
\text { (estoque elevado) }\end{array}$ & $\begin{array}{l}\text { Depto. de Compras } \\
\text { - desconto sobre as } \\
\text { quantidades a serem } \\
\text { compradas. }\end{array}$ & $\begin{array}{l}\text { Depto. Financeiro } \\
\text { - capital investido e perda } \\
\text { financeira. }\end{array}$ \\
\hline $\begin{array}{c}\text { Material em Processo } \\
\text { (estoque elevado) }\end{array}$ & $\begin{array}{l}\text { Depto. de Produção } \\
\text { - nenhum risco de falta de } \\
\text { materiais e grandes lotes } \\
\text { de fabricação. }\end{array}$ & $\begin{array}{l}\text { Depto Financeiro } \\
\text { - maior risco de perdas e } \\
\text { obsolescência e aumento } \\
\text { do custo de manutenção. }\end{array}$ \\
\hline $\begin{array}{l}\text { Produto Acabado } \\
\text { (estoque elevado) }\end{array}$ & $\begin{array}{l}\text { Depto. de Vendas } \\
\text { - entregas rápidas, boa } \\
\text { imagem, melhores } \\
\text { vendas. }\end{array}$ & $\begin{array}{l}\text { - capital investido, maior } \\
\text { custo de armazenagem. }\end{array}$ \\
\hline
\end{tabular}

Fonte: Dias, (1993, p. 24).

Para a empresa, o principal objetivo é, sem dúvida, maximizar o lucro sobre o capital investido em: fábricas, equipamentos, financiamentos, reserva de caixa e estoques. 
Podemos então esperar que o dinheiro que está investido em estoques seja o lubrificante necessário para a produção e o bom atendimento das vendas.

$\mathrm{O}$ investimento em estoque tem como objetivo estratégico maximizar os recursos da empresa, através da possibilidade de aumento na eficiência operacional e fornecer um nível satisfatório de atendimento ao cliente, por meio de disponibilizar a pronta entrega o produto almejado pelo consumidor.

O objetivo, portanto, da gestão de estoques é otimizar o investimento em estoques, aumentando o uso eficiente dos meios da empresa, minimizando as necessidades de capital investido.

Embora o estoque seja um requisito primordial para a organização, não se pode deixar de ressaltar que ele também deve ser visto como capital imobilizado. Uma mercadoria que, muita das vezes, foi paga antes de conseguir ser vendida ao cliente, poderia, em alguns casos, ser investido em outros segmentos da organização, gerando outras fontes de renda ou lucro.

Ballou (1993) afirma que "estoque imobiliza capital que poderia ser empregado de forma diferente dentro ou fora da organização".

Sua gestão implica na tomada de decisões e ações que afetam a quantidade destes bens ou materiais ao longo do tempo, que acarretam benefícios e custos para a organização. O caráter dinâmico das quantidades no tempo tornam as decisões de quanto e quando abastecer os estoques de cada item as mais importantes dos modelos de gestão na busca dos objetivos de custos e atendimento da demanda.

Embora o estoque seja algo necessário para a organização, ele também demanda custo, sendo sua gestão dividida em três categorias diferentes: custos de manutenção do estoque; custos de compra e custos de falta.

- Custos de manutenção de estoque: são todos os custos necessários para manter o estoque por um determinado período de tempo, incluindo os custos de oportunidades de capital, impostos, seguros, custos de armazenagem física e os custos de riscos de deterioração, obsolescência, danos e furtos.

- Custos de compra: Ballou (1993) afirma que os custos de compra estão "associados ao processo de aquisição das quantidades requeridas para a reposição do estoque". Pode-se afirmar que são todos os gastos relacionados na compra de 
algum produto, abrangendo os custos de processamentos de pedido, contato com o fornecedor, custo de preparação para atendimento do lote solicitado, custo de manuseio realizado na doca de recepção, custo do transporte e o preço da mercadoria.

- Custos de falta: conforme seu entendimento Ballou (1993) define custo de falta como "aqueles que ocorrem caso haja demanda por itens em falta", podendo acarretar uma perda de venda ou atraso. Pode ser inserido neste segmento o custo de compra de fornecedores diferentes com preços mais elevados. Afinal, a falta da mercadoria em estoque gera uma necessidade urgente, induzindo a organização a efetuar uma má compra para não deixar de atender seu cliente potencial.

\subsection{1}

\section{Modelos de Previsão da Demanda Aplicados na Gestão de Estoques}

As organizações necessitam de um sistema de previsão adequado para melhorar o nível de serviço aos clientes, planejar o sistema de reposição de estoques e identificar a necessidade de uma maior capacidade de produção.

De acordo com Hanke e Reitsch (1998), os tipos de previsão disponíveis para uso nas organizações podem ser classificados de diversas formas, tomandose com base alguma característica comum. Assim, eles podem ser de curto prazo ou longo prazo, quando o tempo é a característica considerada, podem ser detalhados ou gerais, dependendo do universo abrangido pela previsão (país, estado, fábrica, produto, etc.), ou podem ser classificados como qualitativos ou quantitativos, dependendo do uso de dados e julgamento humano utilizados.

Os métodos quantitativos manipulam dados históricos, informações do passado que são projetadas para o futuro, implicando na adoção da premissa de que os padrões observados no passado se repetirão no futuro. Já os métodos qualitativos não obedecem necessariamente a esta idéia, admitindo que eventos inexistentes no passado impactem as previsões e, eventualmente, anulem padrões históricos.

Na Figura 1 adaptada de Silver, Pike e Peterson (1998) temos uma sugestão de uma estrutura de um sistema de previsão. Observa-se que esta 
estrutura permite a intervenção humana com a análise do resultado fornecido pelo modelo (análise gerencial). Esta análise torna-se particularmente importante quando fatos atuais como, por exemplo, novas empresas competidoras, concorrentes que saíram do mercado ou promoções não existiam, e, portanto, não estavam implícitos nos dados passados.

Observa-se, também, que temos que medir o erro de previsão, o qual serve para dimensionar os estoques de segurança, para avaliar se o modelo é adequado e para avaliar se as modificações adicionadas na análise gerencial são pertinentes. O monitoramento do erro de previsão pode servir ainda para verificar a presença de viés, que significa que os erros de previsão possuem uma média não nula, indicando que o método de previsão está, insistentemente, subestimando ou superestimando a demanda, o que pode ser indicativo de inadequação do método e/ou mudança no padrão de comportamento da série observada.

Os métodos quantitativos são geralmente subdivididos em dois grupos:

\footnotetext{
- Métodos Estatísticos, que, conforme Hanke e Reitsch (1998), se preocupam com os padrões históricos e suas alterações cíclicas e aleatórias;

- Métodos Determinísticos, que procuram identificar as relações causais entre a variável que necessita de previsão e outras consideradas influentes nesta; embora chamados de determinísticos, estes métodos também se valem de técnicas estatísticas para o estabelecimento das relações causais.
} 


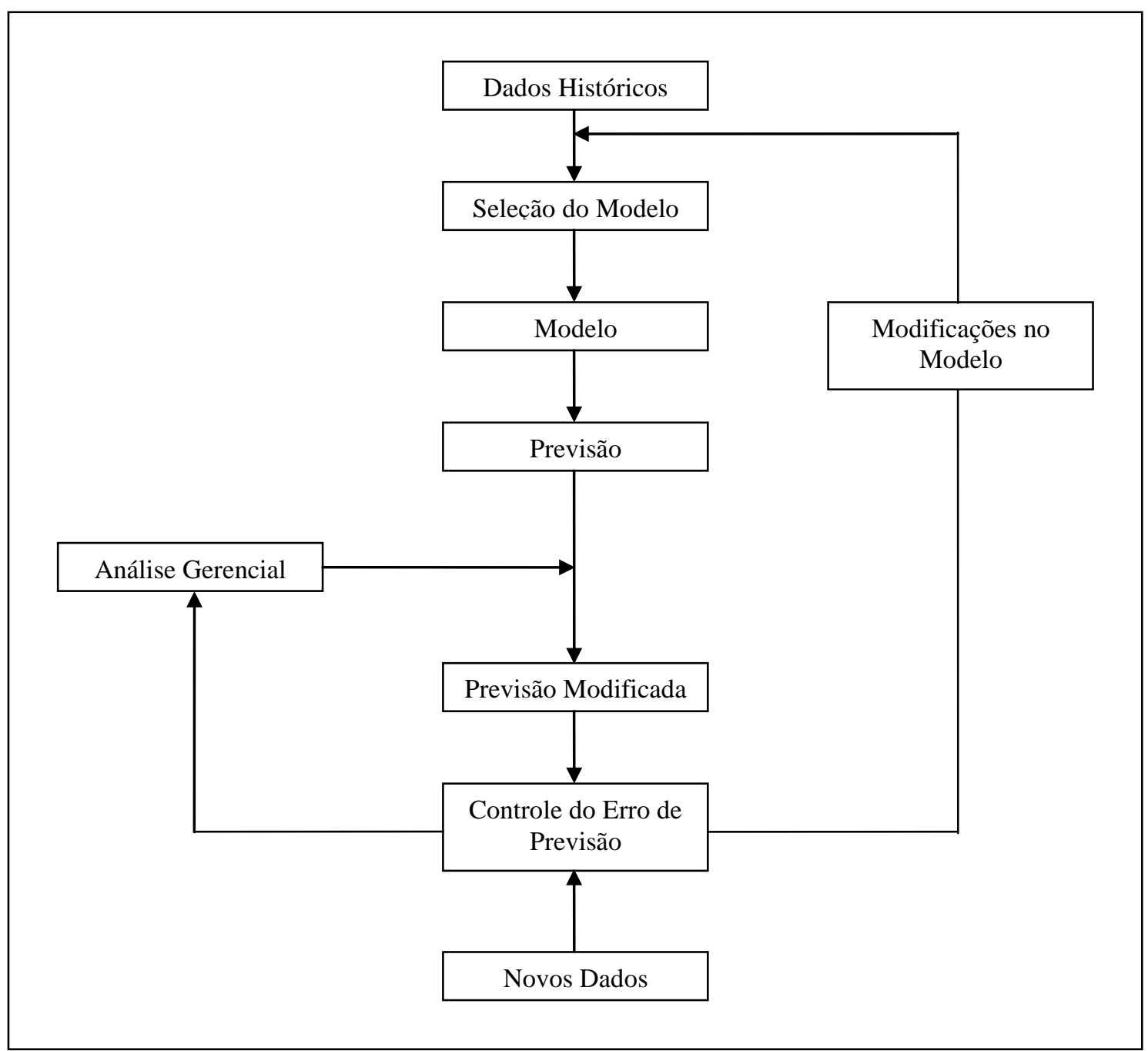

Figura 1 - Estrutura de um Sistema de Previsão

Fonte: Adaptado de Silver, Pike e Peterson, (1998).

Como observa Santoro (2006), os métodos estatísticos são função apenas do tempo e da hipótese de comportamento adotada, e costumam ser de aplicação mais simples que os determinísticos, que geralmente requerem desdobramentos sobre o comportamento futuro das outras variáveis influentes.

\section{Modelos Quantitativos Estatísticos de Previsão de Demanda}

Para previsão da demanda de curto prazo temos três modelos:

- Modelo Constante: é o modelo em que não se observa tendência de crescimento ou decrescimento na demanda, a qual varia em torno de um nível: $x_{t}=a+\varepsilon_{t}$, 
onde $a$ é o nível da demanda e $\varepsilon$ é um "termo de erro" com média zero e variância $\sigma^{2}$

- Modelo Linear: é o modelo em que se observa tendência de crescimento ou decrescimento na demanda: $x_{t}=a+b_{t}+\varepsilon_{t}$, onde $a$ é o nível da demanda, $b$ é a taxa de crescimento (ou decrescimento) da demanda e $\varepsilon$ é um "termo de erro" com média zero e variância $\sigma^{2}$;

- Modelo Sazonal: é o modelo em que, além da tendência de crescimento ou decrescimento na demanda, observam-se variações na demanda conforme a época do ano (sazonalidade): $x_{t}=\left(a+b_{t}\right) F_{t}+\varepsilon_{t}$, onde $a$ é o nível da demanda, $b$ é a taxa de crescimento (ou decrescimento) da demanda, $F_{t}$ é o fator de sazonalidade no período $t$ e $\varepsilon$ é um "termo de erro" com média zero e variância $\sigma^{2}$.

Diversos métodos podem ser utilizados para as estimativas dos parâmetros de cada um destes modelos. Neste trabalho focaremos nos modelos constante e linear, já que, no ciclo de vida da produção de um reservatório de petróleo, a produção tende a ser linear com tendência de crescimento no início do ciclo, linear com tendência de decrescimento no fim do ciclo, e constante no restante do ciclo de vida.

\section{Modelo Constante utilizando Média Simples}

Este tipo de modelo utiliza a média simples da amostra para estimar o parâmetro $a$ da equação do modelo constante: $x_{t}=a+\varepsilon_{t}$, onde $a$ é o nível da demanda e $\varepsilon$ é um "termo de erro" com média zero e variância $\sigma^{2}$. Uma forma adequada e frequentemente utilizada quando se possui um histórico razoável da demanda passada é estimar os parâmetros do modelo utilizando esses dados. Quanto maior o número de observações, melhor. A quantidade mínima de observações que pode ser considerada adequada depende da variabilidade da demanda e do uso que será feito da previsão, mas, como regra prática, em torno de trinta observações é uma amostra satisfatória.

Para estimar o nível da demanda $\hat{a}_{t}$ para um determinado período $(t)$, calculamos a média de todas as observações passadas. E a previsão para os 
períodos subsequentes é $x_{t, t+\tau}=\hat{a}_{t}$, onde $x_{t, t+\tau}$ é a previsão, feita no período $t$, da demanda no período $t+\tau$ (para $\tau=1,2,3 \ldots$ ).

\section{Modelo Constante utilizando Média Móvel}

$\mathrm{Na}$ realidade, quando dizemos que a demanda média não varia com o tempo queremos dizer que não temos razões para crer que varie muito e não temos uma indicação de como varia. Entretanto, se tirarmos a média das primeiras "N" observações e das últimas "N", vemos que as mesmas podem ser bem diferentes. Portanto, constatamos que a média tem certa flutuação e, portanto, os dados antigos não são tão confiáveis quanto os mais recentes. Daí surge a idéia de se estimar o nível da demanda $\hat{a}_{t}$ usando apenas as últimas "N" observações. Isto é, para o cálculo da média móvel, descartamos a observação do período mais antigo da última previsão e incluímos a observação mais recente.

Um procedimento recomendado para verificar o comportamento das previsões é efetuar uma simulação da previsão para um período passado, considerando sempre as " $\mathrm{N}$ " observações anteriores.

É apresentado, através da Tabela 3, um exemplo de simulação da previsão da demanda com uma média móvel de dez semanas. Neste exemplo, a partir da semana 11 são consideradas as últimas dez observações. 
Tabela 3 - Simulação da Previsão de Demanda com uma Média Móvel de 10 semanas

\begin{tabular}{cccccc}
\hline Semana & Demanda & & Semana & Demanda & Previsão \\
\hline 1 & 20 & & 21 & 28 & 22.2 \\
2 & 19 & & 22 & 24 & 22.8 \\
3 & 18 & & 23 & 18 & 22.8 \\
4 & 23 & & 24 & 19 & 22.8 \\
5 & 19 & & 25 & 26 & 22.8 \\
6 & 22 & & 26 & 24 & 23.0 \\
7 & 25 & & 27 & 26 & 23.2 \\
8 & 22 & & 28 & 21 & 23.4 \\
9 & 24 & & 29 & 30 & 23.4 \\
10 & 23 & Previsão & 30 & 20 & 24.1 \\
11 & 22 & 21.5 & 31 & 24 & 23.6 \\
12 & 24 & 21.7 & 32 & 14 & 23.2 \\
13 & 18 & 22.2 & 33 & 25 & 22.2 \\
14 & 19 & 22.2 & 34 & 25 & 22.9 \\
15 & 24 & 21.8 & 35 & 26 & 23.5 \\
16 & 22 & 22.3 & 36 & 16 & 23.5 \\
17 & 24 & 22.3 & 37 & 23 & 22.7 \\
18 & 21 & 22.2 & 38 & 23 & 22.4 \\
19 & 23 & 22.1 & 39 & 26 & 22.6 \\
20 & 25 & 22.0 & 40 & 24 & 22.2 \\
& & & 41 & & 22.6 \\
\hline
\end{tabular}

Fonte: O autor, (2012).

Com os dados da Tabela 3 é possível construir o Gráfico 1, onde observamos o comportamento da previsão em relação aos dados reais.

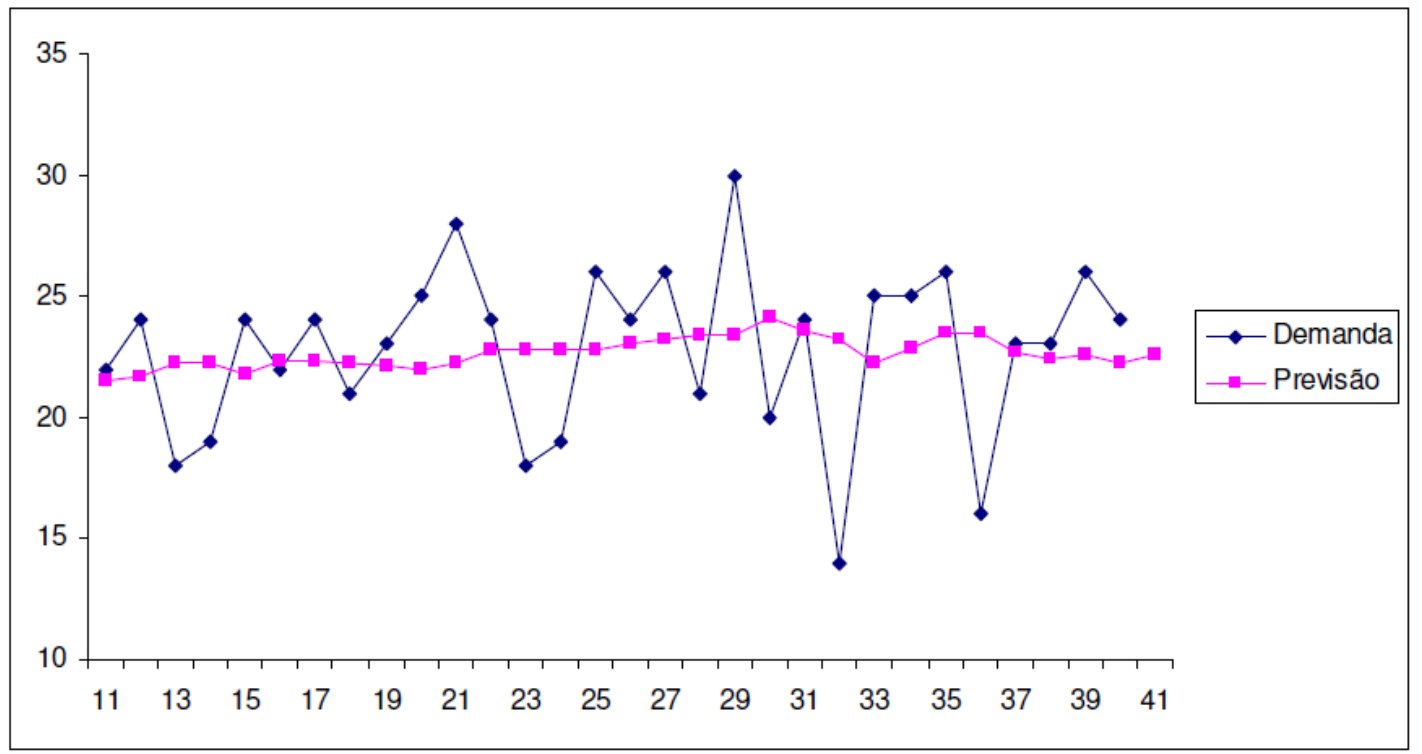

Gráfico 1 - Demanda x Previsão com Média Móvel Fonte: O autor, (2012). 


\section{Modelo Constante utilizando Amortecimento Exponencial Simples}

Quando utilizamos a média móvel, estamos dando o mesmo peso às últimas "N" observações e desconsiderando completamente as anteriores. Através do método de amortecimento exponencial, atribuímos pesos maiores às observações mais recentes e pesos menores às observações mais antigas.

Sabemos que a equação do modelo constante é: $x_{t}=a+\varepsilon_{t}$, onde $a$ é o nível da demanda e $\varepsilon$ é um "termo de erro" com média zero e variância $\sigma^{2}$;

Chamaremos de $\hat{a}_{t}$ o valor da $t$-ésima estimativa de $a$. Seja $0<\alpha<1$ a constante de amortecimento (conforme será discutido adiante), o valor da estimativa $\hat{a}_{t}$ é obtido pelo método do amortecimento exponencial através da seguinte equação:

$$
\hat{a}_{t}=\alpha x_{t}+(1-\alpha) \hat{a}_{t-1}
$$

Para cada nova observação $x_{t}$, obtemos uma nova estimativa $\hat{a}_{t}$.

Repare que se $\alpha=1$, então a estimativa é sempre a última observação (ou seja, descartam-se todas as informações anteriores e fica-se apenas com a última); e se $\alpha=0$ todas as estimativas são iguais à inicial (ou seja, não se usa nenhuma informação nova). Na prática, portanto, estes valores extremos nunca serão utilizados. Quanto maior $\alpha$, maior é o peso que a última observação tem na previsão da estimativa. Veremos mais adiante como escolher o melhor valor para $\alpha$.

Supondo que dispomos de $t$ observações da demanda: $x_{1}, x_{2}, \ldots, x_{t}$, e que o processo de previsão foi iniciado na ocasião da observação $x_{1}$, temos, pela equação 1, que a previsão feita ao fim do período $t$, quando obtivemos a observação $x_{1}$, é:

$$
\hat{a}_{t}=\sum_{j=0}^{t-1} \alpha(1-\alpha)^{j} x_{t-j}
$$

Portanto, $\hat{a}_{t}$ é uma média ponderada das demandas anteriores, cujo peso da observação $x_{t-j}$ é $\alpha(1-\alpha)^{j}$. 
É apresentado, através da Tabela 4, um exemplo de simulação da previsão da demanda com amortecimento exponencial. Foram considerados como base os valores da Tabela 3 e $\alpha=0,05$.

Para obter o valor inicial da estimativa, considerou-se $\hat{a}_{0}$ igual à média das dez primeiras observações $(=21,50)$.

Com os dados da Tabela 4, podemos construir o Gráfico 2, onde observamos o comportamento da previsão em relação à demanda real.

Tabela 4 - Simulação da Previsão com Amortecimento Exponencial

\begin{tabular}{cccccc}
\hline Semana & Demanda & & Semana & Demanda & Previsão \\
\hline 1 & 20 & & 21 & 28 & 21,83 \\
2 & 19 & & 22 & 24 & 22,13 \\
3 & 18 & & 23 & 18 & 22,23 \\
4 & 23 & & 24 & 19 & 22,02 \\
5 & 19 & & 25 & 26 & 21,87 \\
6 & 22 & & 26 & 24 & 22,07 \\
7 & 25 & & 27 & 26 & 22,17 \\
8 & 22 & & 28 & 21 & 22,36 \\
9 & 24 & & 29 & 30 & 22,29 \\
10 & 23 & Previsão & 30 & 20 & 22,67 \\
11 & 22 & 21,50 & 31 & 24 & 22,54 \\
12 & 24 & 21,52 & 32 & 14 & 22,61 \\
13 & 18 & 21,65 & 33 & 25 & 22,19 \\
14 & 19 & 21,47 & 34 & 25 & 22,33 \\
15 & 24 & 21,34 & 35 & 26 & 22,46 \\
16 & 22 & 21,48 & 36 & 16 & 22,63 \\
17 & 24 & 21,50 & 37 & 23 & 22,30 \\
18 & 21 & 21,63 & 38 & 23 & 22,34 \\
19 & 23 & 21,59 & 39 & 26 & 22,37 \\
20 & 25 & 21,66 & 40 & 24 & 22,55 \\
\hline
\end{tabular}

Fonte: O autor, (2012). 


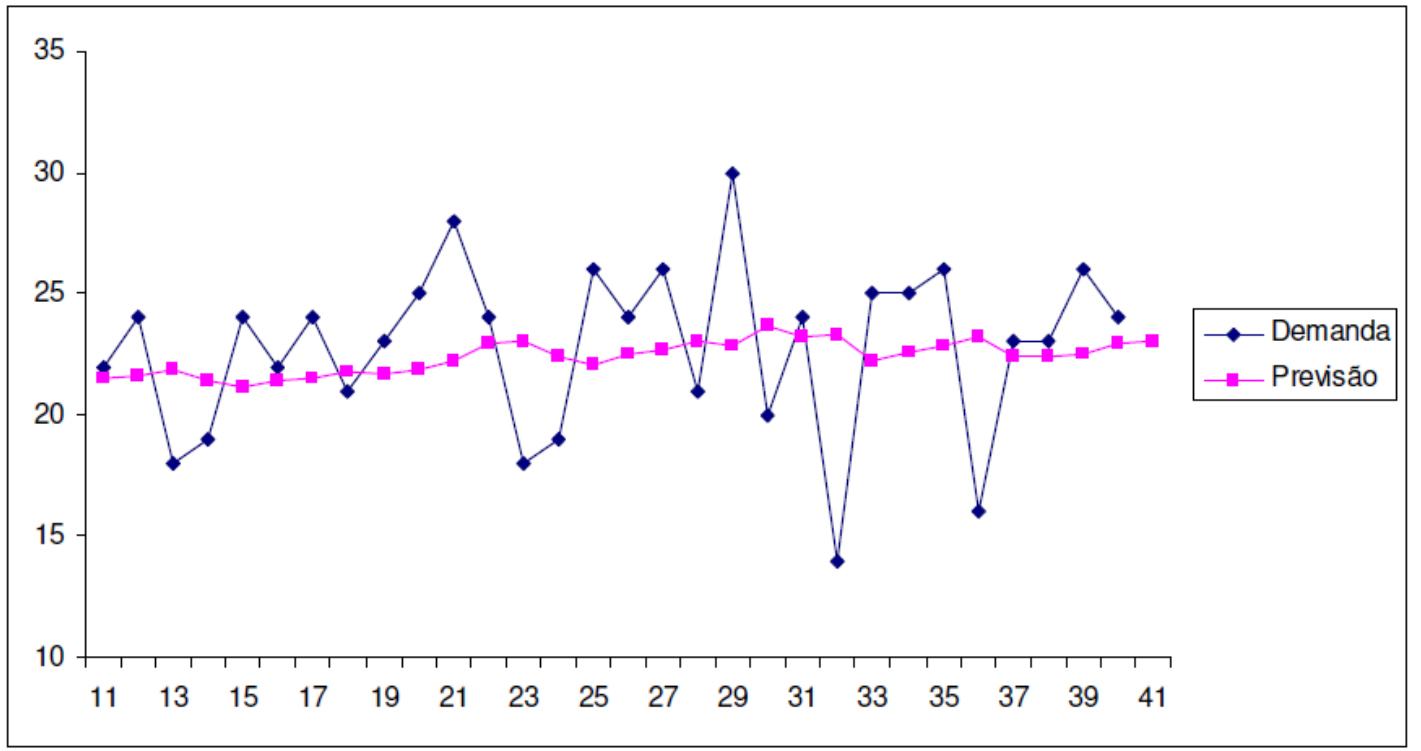

Gráfico 2 - Demanda x Previsão com Amortecimento Exponencial Fonte: O autor, (2012).

\section{Escolha da Constante de Amortecimento (a) para o Modelo Constante}

Em aplicações práticas, devemos usar valores entre 0,01 e 0,3. Um valor recomendado é 0,10 (SILVER; PIKE; PETERSON, 1998). Entretanto, podemos escolher um valor de $\alpha$ que minimize o erro médio quadrático (EMQ), que vem a ser uma estimativa da variância do erro de previsão.

$$
E M Q=\frac{1}{n} \sum_{i=1}^{n}\left(x_{t}-\hat{x}_{t-1, t}\right)^{2}
$$

Podemos atribuir vários valores a $\alpha$ e selecionar aquele cujo valor de $E M Q$ seja mínimo. Com a ferramenta solver da planilha Excel é possível achar este valor.

\section{Modelo Linear utilizando Amortecimento Exponencial Duplo}

O modelo constante pressupõe que a demanda permanece essencialmente (isto é, a menos de variações aleatórias) a mesma durante um longo período de tempo. Isto certamente não é adequado quando sabemos que a demanda do produto está crescendo de forma significativa, ou ao contrário, está subitamente em declínio. Por exemplo, quando um produto está na fase de crescimento de seu 
ciclo de vida (o que pode durar alguns anos), ou então, quando uma empresa está em fase de expansão e sabe que sua demanda está crescendo e deverá continuar crescendo nos próximos meses, não é razoável supor que a demanda é essencialmente constante.

Vimos que o modelo com tendência é $x_{t}=a+b_{t}+\varepsilon_{t}$. Para se inicializar a previsão, é preciso utilizar a regressão linear por mínimos quadrados, para determinar os valores iniciais das estimativas de $a$ e $b$. Sendo a previsão $\hat{x}_{t}=\hat{a}+\hat{b} t$, então a soma dos erros quadráticos é $S=\sum_{i=1}^{n} e_{t}^{2}=\left[x_{t}-(\hat{a}+\hat{b} t)\right]^{2}$.

Para minimizar $\mathrm{S}$, igualamos a zero as derivadas parciais em relação a $a$ e $b$ e, resolvendo o sistema de equações, temos as estimativas iniciais dos parâmetros $a$ e $b$ :

$$
\begin{gathered}
\hat{b}=\frac{\sum_{i=1}^{n} t x_{t}-\frac{(n+1)}{2} \sum_{i=1}^{n} x_{t}}{n\left(n^{2}-1\right) / 12} \\
\hat{a}=\sum_{i=1}^{n} \frac{x_{t}}{n}-\frac{\hat{b}(n+1)}{2}
\end{gathered}
$$

Sejam $\hat{a}_{t}$ e $\hat{b}_{t}$ os valores das $t$-ésimas estimativas de $a$ e $b$, através do procedimento de Holt (SILVER et al., 1998):

$$
\begin{gathered}
\hat{a}_{t}=\alpha_{H W} x_{t}+\left(1-\alpha_{H W}\right)\left(\hat{a}_{t-1}+\hat{b}_{t-1}\right) \\
\hat{b}_{t}=\beta_{H W}\left(\hat{a}_{t}-\hat{a}_{t-1}\right)+\left(1-\beta_{H W}\right) \hat{b}_{t-1}
\end{gathered}
$$

A previsão para as semanas subsequentes é:

$$
\hat{x}_{i, t+\tau}=\hat{a}_{i}+\hat{b} \tau
$$


Onde $\hat{x}_{t, t+\tau}$ é a previsão, feita na semana $t$, da demanda da semana $t+\tau$ (para $\tau=$ $1,2,3 \ldots)$.

É apresentado, através da Tabela 5, um exemplo da demanda mensal de um produto químico (em toneladas).

Tabela 5 - Demanda Mensal de um produto químico (toneladas)

\begin{tabular}{|c|c|c|c|c|c|c|c|c|c|c|c|}
\hline Ano & Mês & $\mathrm{t}$ & Demanda & Ano & Mês & $\mathrm{t}$ & Demanda & Ano & Mês & $\mathrm{t}$ & Demanda \\
\hline \multirow[t]{12}{*}{2003} & janeiro & 1 & 4,10 & 2004 & janeiro & 13 & 14,12 & 2005 & janeiro & 25 & 22,17 \\
\hline & fevereiro & 2 & 4,44 & & fevereiro & 14 & 15,20 & & fevereiro & 26 & 25,67 \\
\hline & março & 3 & 5,20 & & março & 15 & 16,34 & & março & 27 & 24,32 \\
\hline & abril & 4 & 4,40 & & abril & 16 & 14,23 & & abril & 28 & 25,43 \\
\hline & maio & 5 & 6,11 & & maio & 17 & 18,54 & & maio & 29 & 27,12 \\
\hline & junho & 6 & 5,77 & & junho & 18 & 16,20 & & junho & 30 & 28,32 \\
\hline & julho & 7 & 7,99 & & julho & 19 & 18,30 & & & & \\
\hline & agosto & 8 & 10,12 & & agosto & 20 & 20,20 & & & & \\
\hline & setembro & 9 & 8,65 & & setembro & 21 & 21,84 & & & & \\
\hline & outubro & 10 & 11,12 & & outubro & 22 & 21,67 & & & & \\
\hline & novembro & 11 & 12,80 & & novembro & 23 & 22,12 & & & & \\
\hline & dezembro & 12 & 12,34 & & dezembro & 24 & 23,23 & & & & \\
\hline
\end{tabular}

Fonte: $\mathrm{O}$ autor, (2012).

Observa-se o crescimento da demanda, o que recomenda o modelo linear com tendência. Vamos utilizar os dez primeiros meses para inicializar a previsão. Através das equações 17 e 18 chegamos aos valores iniciais de $\hat{a}_{10}(=10,23)$ e $\hat{b}_{10}$ $(=0,77)$. É possível obter estes valores através do software Excel, da Microsoft, construindo o gráfico da demanda mensal e, em seguida, marcando as opções "adicionar linha de tendência" e "exibir a equação do gráfico", como é apresentado no Gráfico 3.

Com estes valores iniciais e considerando $\alpha_{H W}=0,17$ e $\beta_{H W}=0,09$ podemos fazer uma simulação da previsão, para um mês adiante, a partir do mês 11, como é apresentado na Tabela 6. 


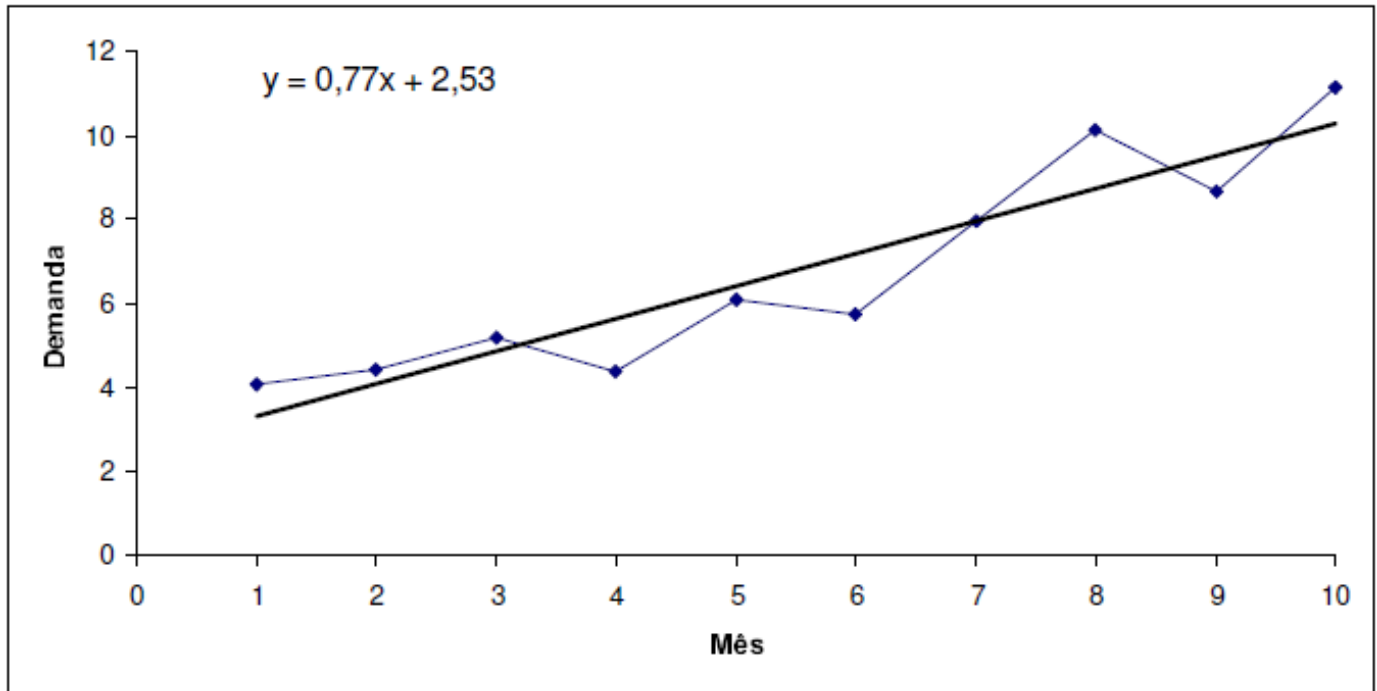

Gráfico 3 - Demanda e Linha de Regressão Fonte: O autor, (2012).

Tabela 6 - Demanda Mensal de um produto químico (toneladas)

\begin{tabular}{llccccc}
\hline Mês & $t$ & Demanda & $a_{t}$ & $b_{t}$ & $a_{t}+b_{t}$ & Previsão \\
\hline outubro & 10 & 11,12 & 10,23 & 0,77 & 11,00 & \\
novembro & 11 & 12,80 & 11,31 & 0,80 & 12,11 & 11,00 \\
dezembro & 12 & 12,34 & 12,15 & 0,80 & 12,95 & 12,11 \\
janeiro & 13 & 14,12 & 13,15 & 0,82 & 13,97 & 12,95 \\
fevereiro & 14 & 15,20 & 14,18 & 0,84 & 15,02 & 13,97 \\
março & 15 & 16,34 & 15,25 & 0,86 & 16,10 & 15,02 \\
abril & 16 & 14,23 & 15,78 & 0,83 & 16,61 & 16,10 \\
maio & 17 & 18,54 & 16,94 & 0,86 & 17,80 & 16,61 \\
junho & 18 & 16,20 & 17,52 & 0,83 & 18,36 & 17,80 \\
julho & 19 & 18,30 & 18,35 & 0,83 & 19,18 & 18,36 \\
agosto & 20 & 20,20 & 19,36 & 0,85 & 20,20 & 19,18 \\
setembro & 21 & 21,84 & 20,49 & 0,87 & 21,36 & 20,20 \\
outubro & 22 & 21,67 & 21,41 & 0,88 & 22,29 & 21,36 \\
novembro & 23 & 22,12 & 22,26 & 0,88 & 23,14 & 22,29 \\
dezembro & 24 & 23,23 & 23,15 & 0,88 & 24,03 & 23,14 \\
janeiro & 25 & 22,17 & 23,71 & 0,85 & 24,56 & 24,03 \\
je0reiro & 26 & 25,67 & 24,75 & 0,87 & 25,61 & 24,56 \\
feverein & 27 & 24,32 & 25,39 & 0,85 & 26,24 & 25,61 \\
março & 28 & 25,43 & 26,10 & 0,83 & 26,93 & 26,24 \\
abril & 29 & 27,12 & 26,96 & 0,84 & 27,80 & 26,93 \\
maio & 28 & 28,32 & 27,89 & 0,84 & 28,73 & 27,80 \\
junho & 30 & & & & & 28,73
\end{tabular}

Fonte: O autor, (2012).

Utilizando a equação 8, podemos calcular a previsão para o mês 31 e meses subsequentes:

$$
\hat{x}_{30,30+\tau}=\hat{a}_{30}+\ddot{b}_{30} \tau=27,89+0,84 \tau, \tau=1,2,3 \ldots
$$


Com os dados da tabela 6, podemos construir o gráfico 4, onde observamos o comportamento da previsão em relação à demanda real.

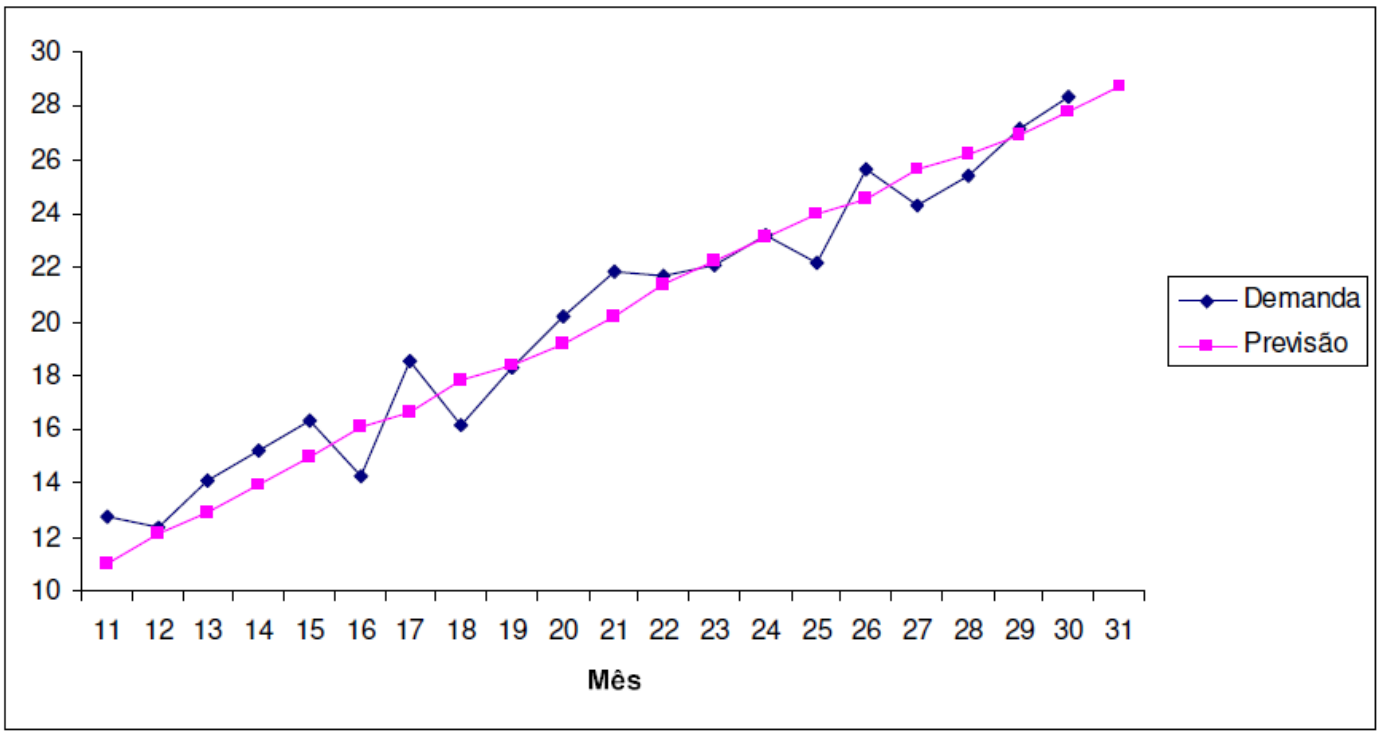

Gráfico 4 - Demanda x Previsão com Amortecimento Exponencial Duplo Fonte: O autor, (2012).

\section{Escolha das Constantes de Amortecimento ( $\alpha$ e $\beta$ ) para o Modelo com Tendência}

Em aplicações práticas, devemos usar valores de $\alpha_{H W}$ entre 0,01 e 0,3 e valores de $\beta_{H W}$ entre 0,005 e 0,18 . Valores recomendados são $\alpha_{H W}=0,10$ e $\beta_{H W}=$ 0,05 (SILVER et al., 1998).

Como já foi visto, podemos escolher valores de $\alpha_{H W}$ e $\beta_{H W}$ que minimizem o erro médio quadrático (EMQ), que vem a ser uma estimativa da variância do erro da previsão.

$$
E M Q=\frac{1}{n} \sum_{i=1}^{n}\left(x_{t}-\hat{x}_{t-1, t}\right)^{2}
$$

Podemos atribuir vários valores a $\alpha_{H W}$ e $\beta_{H W}$ e selecionar aqueles cujo valor de $E M Q$ seja mínimo. Com a ferramenta solver da planilha Excel é possível obter este valor. 


\section{Diagnóstico da Situação Atual e Necessidades de Melhoria}

Este capítulo apresenta um breve resumo do processo atual de planejamento do escoamento da produção e dos estoques de petróleo da companhia e os seus direcionadores, destacando a importância da previsão da produção para a tomada de decisão quanto à alocação correta para cada tipo petróleo produzido. Posteriormente, é descrito o diagnóstico da situação atual dos processos da área de Exploração e Produção, escopo deste trabalho, que influenciam os níveis de estoque nas plataformas, com ênfase nos seus fluxos de informações, sistemas e indicadores. E por fim, são apresentadas as necessidades de melhoria e a proposta de implantação de um processo estruturado de gestão de estoques nas unidades marítimas de armazenagem e escoamento de petróleo da empresa.

\section{$\underline{\text { Processo Atual de Planejamento do Escoamento da Produção }}$}

A Petrobras possui 35 plataformas de armazenagem e escoamento da produção marítima de petróleo, divididas em 7 unidades operacionais (UOs), 5 bacias e 5 estados brasileiros, formando um grande sistema produtivo cuja produção é escoada através de navios petroleiros. O petróleo, depois de produzido, pode ser refinado em uma refinaria própria da empresa ou exportado.

Este complexo sistema produtivo exige uma boa estimativa de produção de óleo, água e gás a serem produzidos em cada período, possibilitando assim, um adequado planejamento não só do segmento da empresa responsável pela produção de petróleo, como também dos segmentos de transporte, refino e comercialização. A partir daí, surge uma atividade importante denominada "Previsão Operacional da Produção de Óleo e Água", que consiste em estimar os volumes de óleo e água que serão produzidos em cada plataforma e escoados pelos diversos pontos de escoamento até seu destino final. Esta curva de produção e escoamento possui dois horizontes distintos de tempo. A curva com horizonte de 
quinze meses é utilizada pela área de Planejamento da Logística, do segmento Abastecimento (responsável pelo transporte, refino e comercialização do óleo), para simular e projetar a alocação de cada tipo de óleo para cada refinaria nacional ou para exportação, de modo a maximizar o resultado da companhia, conforme será mencionado nos próximos parágrafos. A outra curva de produção e escoamento de óleo e água, denominada Estimativa Trimestral de Produção, possui um horizonte de três meses, é atualizada semanalmente, e é utilizada pela área de Suprimento de Petróleo, também do segmento Abastecimento, para programação dos navios petroleiros que escoam a produção para os terminais terrestres, para posterior envio para as refinarias, ou para exportação, que pode ser realizada diretamente dos pontos de escoamento ou pelos terminais terrestres. Estes pontos de escoamento de petróleo podem ser oleodutos ou terminais oceânicos, isto é, terminais especialmente desenvolvidos para receber navios petroleiros que atracam e escoam a produção. Os nomes destes terminais oceânicos são "Floating Production Storage and Offloading" (FPSO), que são navios petroleiros adaptados para receber a produção dos poços, processar e armazenar o óleo em seus tanques, para posterior escoamento para outro navio petroleiro, ou "Floating Storage and Offloading" (FSO), cuja diferença para o primeiro é que este não processa o óleo, recebendo óleo já tratado por outra plataforma através de dutos que as interligam.

A área de Planejamento da Logística, do segmento Abastecimento, é a responsável pelo planejamento dos estoques de petróleo da companhia e seus principais direcionadores:

- Definir e manter estoques mínimos de óleo nas refinarias em função do nível de serviço requerido para garantir a carga máxima da primeira planta de processamento de uma refinaria, que é a unidade de destilação, de modo que as refinarias maximizem a produção de derivados;

- Definir e manter estoques mínimos de óleo nos terminais em função do nível de serviço requerido para garantir a demanda de envio para as refinarias;

- Evitar perda de produção de petróleo por falta de espaço de armazenagem nas plataformas. Ou seja, é feita a gestão do espaço disponível de cada plataforma para armazenagem da produção, de maneira que quando a plataforma chega num 
determinado nível de estoque, são programados navios para garantir o escoamento da sua produção para os terminais.

Como atualmente o perfil metalúrgico das refinarias nacionais não permite que $100 \%$ da demanda de refino seja atendida com a produção nacional de petróleo, dadas às características de qualidade do óleo produzido no país, cuja maior parte é classificada como óleo pesado ( ${ }^{\circ} \mathrm{API}$ menor que 22), é necessário importar óleo do tipo leve ( ${ }^{\circ} \mathrm{API}$ maior que 30 ). Como consequiência, em torno de $80 \%$ da produção nacional de petróleo é processada nas refinarias nacionais e o restante é exportado.

As decisões de importação e exportação levam em conta as metas estipuladas de estoque e inúmeras outras variáveis, como a qualidade e o estoque do óleo armazenado em toda a companhia, a produção de petróleo, preço do petróleo e dos derivados, demanda de derivados no mercado nacional, paradas programadas de produção das plataformas e refinarias, custos de transporte, entre outras. Como as variáveis são muitas, é utilizado um modelo matemático de programação linear denominado PLANAB (Plano de Abastecimento), que representa as atividades da cadeia de suprimento de petróleo e derivados da empresa, desde a transferência de petróleo oriundo da produção até a entrega aos terminais e refinarias nacionais e aos clientes no exterior, para simular e projetar a alocação de cada tipo de óleo para cada refinaria nacional ou para exportação, que tipo de óleo importar, importação e exportação de derivados, dentre outras decisões, de modo a maximizar o resultado da companhia.

Metas de estoque são definidas para petróleo e derivados, cuja responsabilidade pelo cumprimento cabe à área de Logística do Abastecimento. Estas metas são definidas em função da cobertura de estoque de petróleo e de derivados, sendo a cobertura de estoque de petróleo calculada através da seguinte fórmula:

Cobertura de estoque $($ dias $)=$ estoque médio (m3) demanda exportação (m3/dia) + demanda refino (m3/dia)

Pelo exposto, a previsão de produção é muito importante tanto no processo de planejamento de médio prazo do abastecimento das refinarias e das tomadas de 
decisão de importação e exportação de petróleo quanto no processo de curto prazo de programação de navios para o escoamento da produção marítima.

\section{1}

\section{Diagnóstico da Situação Atual}

Para realizar o diagnóstico da situação atual dos processos que influenciam os níveis de estoque das plataformas, se fez necessário conhecer cada um deles e a estratégia utilizada para alcançar este objetivo foi a convocação de reuniões e entrevistas com as gerências e os técnicos dos setores responsáveis pelos processos de previsão da produção, processamento, armazenagem e transferência do óleo. Nestas reuniões, foram levantados padrões, normas, procedimentos, atividades, fluxos de informações, interfaces, dados, sistemas e indicadores envolvidos nos respectivos processos.

As reuniões e entrevistas foram realizadas tanto com as gerências e os técnicos das áreas corporativas, responsáveis pelo estabelecimento de diretrizes para os processos operacionais, quanto com as gerências e os técnicos das unidades operacionais, responsáveis por executar os procedimentos nas frentes operacionais, onde efetivamente são realizadas as operações. Esta iniciativa teve por objetivo ganhar apoio e legitimidade de ambas as áreas, uma vez que as pessoas mais capacitadas envolvidas nestes processos estariam participando do projeto, além da aquisição das informações necessárias ao adequado diagnóstico da situação atual, a fim de obter o melhor desenho possível do novo processo.

As áreas corporativas entrevistadas foram:

- Gerência de Planejamento e Controle da Produção: responsável, dentre outras atividades, por definir as diretrizes, padrões, normas e procedimentos para a atividade de planejamento e controle da produção das unidades operacionais e por elaborar a curva de previsão operacional da produção para os 15 meses seguintes, que é atualizada mensalmente, e a estimativa trimestral da produção com horizonte de três meses, atualizada semanalmente; 
- Gerência de Engenharia Naval: responsável, dentre outras atividades, por definir as diretrizes, padrões, normas e procedimentos para as atividades de armazenagem e transferência de petróleo nas plataformas que armazenam e escoam a produção;

- Gerência de Processamento de Fluidos: responsável, dentre outras atividades, por definir as diretrizes, padrões, normas e procedimentos para a atividade de processamento de fluidos (óleo, gás e água) nas plataformas de produção.

As áreas operacionais entrevistadas foram:

- Gerências de Planejamento, Desenvolvimento e Controle da Produção (PDCP) das unidades operacionais da Bacia de Campos e da Bacia de Santos: responsável, dentre outras atividades, pelo controle da produção e acompanhamento do escoamento da produção.

- Centro de Controle Operacional (CCO) da Bacia de Campos: responsável pelo monitoramento da produção e pelo controle do escoamento da produção, atuando como ponto focal das plataformas junto à área de programação de navios do Abastecimento.

- Coordenadores de embarcação (COEMB) das plataformas P-32, P-47 e P-54: responsáveis pela armazenagem e movimentação dos fluidos nos tanques, preparação das cargas (lotes de retirada) e pelo escoamento da produção das plataformas.

Serão apresentados a seguir o levantamento dos sistemas de informação utilizados e os fluxos de informações existentes.

\section{Sistemas utilizados:}

1) SINP-BC (Sistema de Informações de Produção da Bacia de Campos): apesar do nome, este sistema consolida dados de todas as plataformas do sistema Petrobras, localizadas na costa brasileira, não apenas da bacia de Campos. Este nome se deu devido ao início da produção marítima de petróleo em larga escala no Brasil se dar na bacia de Campos, e este sistema foi desenvolvido especificamente para esta bacia, mas ao longo do tempo ocorreram outras 
descobertas nas demais bacias sedimentares e a sua utilização foi estendida para as demais plataformas.

Este sistema está estruturado em boletins, que são planilhas em formato Excel padronizadas pelos ativos de produção, nome dado às bases administrativas das plataformas. Cada boletim tem uma finalidade e as plataformas registram diversos dados em cada boletim. Estas informações são preenchidas diariamente ou por evento, dependendo do tipo de boletim. Após o boletim ser preenchido e salvo, os dados são enviados para um banco de dados e, através do SINP-BC, é possível acessar os boletins preenchidos pelas plataformas e exportá-los para uma planilha Excel. Também podem ser configurados relatórios por plataforma de modo a consolidar, por exemplo, a qualidade do petróleo escoado a cada offloading efetuado num determinado período.

Seguem alguns exemplos de boletins que são preenchidos pelas plataformas:

- BQP (boletim de qualidade do petróleo): são registrados, por evento de transferência, informações de qualidade e volume do óleo transferido, datas de inicio e fim das operações de cada offloading, dentre outras informações;

- BDP (boletim de produção): são registradas informações diárias de produção das plataformas;

- BMP (boletim de movimentação): são utilizados pelas plataformas que não possuem produção, mas armazenam e escoam a produção recebida de outras plataformas. Estas plataformas registram os volumes recebidos de outras plataformas, dentre outras informações.

2) SIPO (Sistema de Informação da Previsão Operacional): sistema que consolida as curvas de previsão de produção de petróleo, informando a média mensal da produção diária (m3/dia):

- curva de previsão operacional, com horizonte de 15 meses, atualizada mensalmente; e - curva de estimativa trimestral, com horizonte de três meses, atualizada semanalmente. 
Este sistema também consolida as previsões de eventos que influenciam as variações na produção, como as paradas programadas e as saídas de poços, que reduzem a produção; e as entradas de novos poços, que aumentam a produção. Possui banco de dados e é possível exportar informações para planilha em formato Excel.

3) SITOP (Situação Operacional das Plataformas): sistema utilizado, originalmente, para troca de informações entre as plataformas e suas bases administrativas. Algumas das informações relacionadas aqui são os estoques de óleo e água das plataformas. Este sistema não possui banco de dados estruturado, sendo de difícil utilização. Além disso, não há uma padronização das informações de estoque entre as diversas plataformas, podendo haver informações com unidades de medida em diferentes temperaturas, considerando ou não a água emulsionada (BSW), etc., o que pode vir a gerar tomadas de decisão baseadas em informações incorretas.

\section{Fluxo de informações:}

- Médio Prazo (12 meses):

A área de planejamento da Logística do Abastecimento recebe mensalmente uma curva de previsão de produção atualizada do SIPO, com horizonte de 15 meses (previsão operacional), que utiliza para o planejamento do abastecimento de derivados, importação e exportação de derivados e de petróleo, alocação dos petróleos nas refinarias nacionais, dentre outras decisões, para os 12 meses seguintes.

- Curto Prazo (3 meses):

A área de programação de navios da Logística do Abastecimento recebe semanalmente uma curva de previsão de produção atualizada do SIPO, com horizonte de três meses (estimativa trimestral), que utiliza para atualizar o planejamento das cargas de exportação, importação e alocação dos petróleos 
nacionais para as refinarias do sistema Petrobras. Com 2 meses de antecedência são fechadas as cargas de exportação junto aos clientes.

- Curtíssimo Prazo (1 semana a 1 mês):

Baseado nas informações de estoque atual de cada plataforma, extraído do SITOP, e da estimativa trimestral mencionada no fluxo de curto prazo, a área de programação de navios calcula os estoques com horizonte de um mês de cada plataforma, de maneira a programar os navios para escoamento da produção para as refinarias. Estas programações são revistas diariamente e fechadas em conjunto com o CCO (Centro de Controle Operacional da Bacia de Campos), que checa se as informações estão corretas e as valida, ou as corrige, atualizando a programação. Neste momento, são checadas informações operacionais, como condições do mar para realização das operações de offloading nos próximos cinco dias, volumes de petróleo dentro das especificações de qualidade disponíveis para a retirada, etc., sendo efetuadas, por vezes, diversas reprogramações ao longo do mesmo dia de acordo com a dinâmica das operações.

Para uma melhor compreensão do diagnóstico, o dividimos em duas partes: previsão da produção e estoques; e gestão operacional dos estoques.

\section{Previsão da Produção e Estoques}

A tomada de decisão para o planejamento do abastecimento das refinarias, importação e exportação de petróleo; e para a programação de navios para o escoamento da produção marítima dependem significativamente da qualidade da previsão de produção de petróleo.

Porém, o processo atual de previsão informa apenas a média mensal da produção diária (m3/dia), sem considerar a qualidade do óleo. Daí, observamos dois tipos de problema. O primeiro diz respeito à quantidade, pois como a previsão da produção trabalha com a média, não é possível obter uma boa estimativa dos estoques de óleo para a data programada para a sua retirada, já que a produção pode variar bastante ao longo do mês, devido à entrada de novos poços, podendo aumentar consideravelmente a produção durante um determinado período, ou devido à saída de poços ou paradas programadas ou emergenciais para 
manutenção dos equipamentos de produção, podendo reduzir significativamente ou até parar a produção por um determinado período. Como conseqüências, podem ocorrer situações indesejáveis no que diz respeito às incertezas nas estimativas de quantidade da produção e do estoque:

- aumento do tempo de estadia do navio (conhecido como sobreestadia) e, conseqüentemente, dos custos de transporte marítimo, caso o navio chegue antes da formação do lote programado para retirada e fique aguardando a formação do lote, além da janela contratada;

- retirada de um lote menor que o programado (conhecido como "praça morta"), caso o navio chegue antes da formação do lote programado para retirada. Esta situação também põe em risco o abastecimento das refinarias ou o cumprimento de um contrato de exportação;

- risco de uma redução ou parada total da produção na plataforma, caso o navio chegue ao ponto de escoamento após este alcançar a sua capacidade máxima de armazenagem, não havendo mais espaço disponível para estocar o óleo produzido; - necessidade de importação de óleo devido ao risco de não atendimento à demanda de refino. Neste caso, uma importação efetuada sem o devido planejamento reduz a margem de negociação com o vendedor e eleva os custos de importação da companhia.

O segundo tipo de problema diz respeito à qualidade, já que a produção de água de um reservatório aumenta ao longo da sua vida útil, principalmente em função da injeção de água para manter a sua pressão, possibilitando a elevação e o escoamento do óleo desde o reservatório até a superfície. Com este aumento da produção de água, torna-se muito importante a eficiência do processamento do óleo, que tem como objetivo enquadrá-lo nas especificações requeridas pelas refinarias ou para exportação, que determinam um percentual máximo de água e sedimentos emulsionados ao óleo $(0,5 \%$ ou $1 \%$ de $B S W$ - basic sediments and water - a depender do projeto da plataforma ou da especificação do cliente); bem como a eficiência do tratamento da água, que tem como objetivo enquadrá-la de acordo com a regulamentação do CONAMA para descarte.

Sendo assim, caso ocorra alguma redução na eficiência destas plantas de processamento ou as mesmas estejam em manutenção, pode ocorrer acúmulo de 
estoque de óleo fora da especificação ou desenquadrado (considerado produto semi-acabado), que classificamos como "óleo entre $1 \%$ e $5 \%$ de $B S W$ " ou "óleo acima de $5 \%$ de $B S W$ ', ou pode haver acúmulo de estoque de água nos tanques da plataforma. Para contornar a situação do óleo, há necessidade de aguardar a decantação da água emulsionada ao óleo, mantendo o óleo armazenado no tanque durante dias, a depender da sua densidade, para posterior raspagem (remoção através da sucção efetuada por bombas) da água acumulada no fundo do tanque, até a redução do $B S W$ aos níveis adequados. Este procedimento deve ser efetuado até o retorno da planta de processamento do óleo às condições normais de operação. Com relação à água, há necessidade de armazená-la em tanques específicos até o retorno da planta de tratamento de água às condições normais de operação. Como estes volumes de estoque não são previstos atualmente, podem ocorrer situações indesejáveis no que diz respeito às incertezas nas estimativas de qualidade:

- aumento do tempo de estadia do navio (sobreestadia) e, conseqüentemente, dos custos de transporte marítimo, caso o navio chegue antes da formação do lote programado para retirada, pois parte do óleo previsto como produzido não está disponível para retirada por estar fora da especificação de qualidade para envio à refinaria ou para exportação;

- retirada de um lote menor que o programado ("praça morta"), caso o navio chegue antes da formação do lote programado para retirada, pois parte do óleo previsto como produzido não está disponível para retirada por estar fora de especificação de qualidade. Esta situação também põe em risco o abastecimento das refinarias ou o cumprimento de um contrato de exportação;

- necessidade de retirada do óleo fora da especificação ou da água, em casos extremos, seja pelo tempo necessário para retornar à condição operacional as plantas de processamento do óleo, ou de tratamento da água; ou a depender da emulsão da água no óleo e seu tempo de decantação, para que não haja uma redução ou parada total de produção na plataforma, por não haver mais espaço disponível para armazenar o óleo produzido. Esta situação eleva os custos de transporte marítimo, pois se trata de uma condição indesejada, em que não está sendo transportado produto de valor agregado para venda, sendo necessário o seu transporte para um terminal terrestre para posterior tratamento, elevando os custos 
também de armazenagem nos terminais e/ou de processamento nas refinarias, caso haja necessidade de envio de óleo fora da especificação ao segmento de refino, ainda podendo haver problemas nas instalações nas unidades de refino, devido à corrosividade causada pela água;

- necessidade de importação de óleo devido ao risco de não atendimento à demanda de refino por problemas de qualidade. Neste caso, uma importação efetuada sem o devido planejamento reduz a margem de negociação com o vendedor e eleva os custos de importação da companhia.

Atualmente há um indicador que mede o índice de atendimento à programação de alívios (IAPA), que congela a programação de navios duas vezes por semana (terças e sextas feiras) e compara o número de operações realizadas dentro dos parâmetros estabelecidos com o número total de operações programadas para os três dias subseqüentes, sendo que para uma operação ser considerada dentro do parâmetro, a mesma deve ser realizada dentro das faixas de tolerância acordada, sendo de +/- um dia para a data programada (janela de 72 horas) e de $+/-10 \%$ para o volume programado.

Pela análise dos resultados do indicador IAPA ao longo dos últimos três anos, verifica-se que há oportunidades de melhoria, levando em consideração um baixo índice de atendimento à programação, considerando um horizonte de apenas três dias.

Como esta operação necessita de uma integração muito forte entre a área de Exploração e Produção e a área de Abastecimento, caso uma programação não seja atendida, as causas e as respectivas responsabilidades são apuradas, de forma que ações de melhoria sejam planejadas por cada uma delas. São apresentadas na Tabela 7 as possíveis causas identificadas e a respectiva área responsável para dar andamento às ações de melhoria.

Tabela 7 - Causas e responsabilidades pelo não atendimento do IAPA

\begin{tabular}{|l|l|}
\hline \multicolumn{1}{|c|}{ Causa } & \multicolumn{1}{c|}{ Responsabilidade } \\
\hline Desempenho do Navio & Abastecimento \\
\hline Problema em Terminal & Abastecimento \\
\hline Necessidade de Refino & Abastecimento \\
\hline Alteraçã̃o na Comercializaçẫo de Petróleo & Abastecimento \\
\hline Quantidade de Produto & Exploraçẫo \& Produçẫo \\
\hline Qualidade de Produto & Exploraçẫo \& Produçẫo \\
\hline Disponibilidade do Ponto de Alivio & Exploraçẫo \& Produçẫo \\
\hline Mau Tempo & Abastecimento / Exploraçẫo \& Produçẫo \\
\hline Falha no Fluxo de Informação & Abastecimento / Exploraçẫo \& Produçẫo \\
\hline
\end{tabular}

Fonte: O autor, (2012). 
As causas do não atendimento do indicador, cuja responsabilidade é atribuída exclusivamente à área de Exploração e Produção, seguem os seguintes critérios:

- Quantidade do produto: desvio de 10\%, para mais ou para menos, da quantidade de óleo disponível para retirada em relação à quantidade programada;

- Qualidade do produto: não atendimento às especificações de qualidade acordadas (BSW, salinidade e $\mathrm{H}_{2} \mathrm{~S}$ );

- Disponibilidade do ponto de alívio: indisponibilidade da plataforma para a operação de retirada do petróleo, devido a problemas operacionais, devido à manutenção dos equipamentos do sistema de transferência ou por operações na plataforma que impeçam a operação de transferência, como conexão ou desconexão de poços a plataforma.

Através da análise do IAPA apurado em 2011, observou-se que a área de Exploração e Produção foi responsável por maior parte das causas do não atendimento à programação de alívios, seguido do fluxo de informação. Ou seja, há uma grande oportunidade de melhoria para este processo.

A qualidade e a quantidade do produto são as causas que representam as maiores parcelas do não atendimento à programação de navios, o que reforça a necessidade de incorporar tanto a variável qualidade na previsão de produção como as variações diárias na produção ao longo do mês, proporcionando uma previsão de produção com base diária ao invés de uma média mensal.

Além disso, outras variáveis importantes e que também devem fazer parte da previsão, como a disponibilidade do ponto de alívio, serão apresentadas adiante.

\section{Gestão Operacional dos Estoques}

Como resultado das reuniões e entrevistas, foi elaborado um modelo conceitual, representado através da Figura 2, onde são apresentadas as variáveis que influenciam nos níveis de estoque dos $\mathrm{F}(\mathrm{P}) \mathrm{SOs}$. 


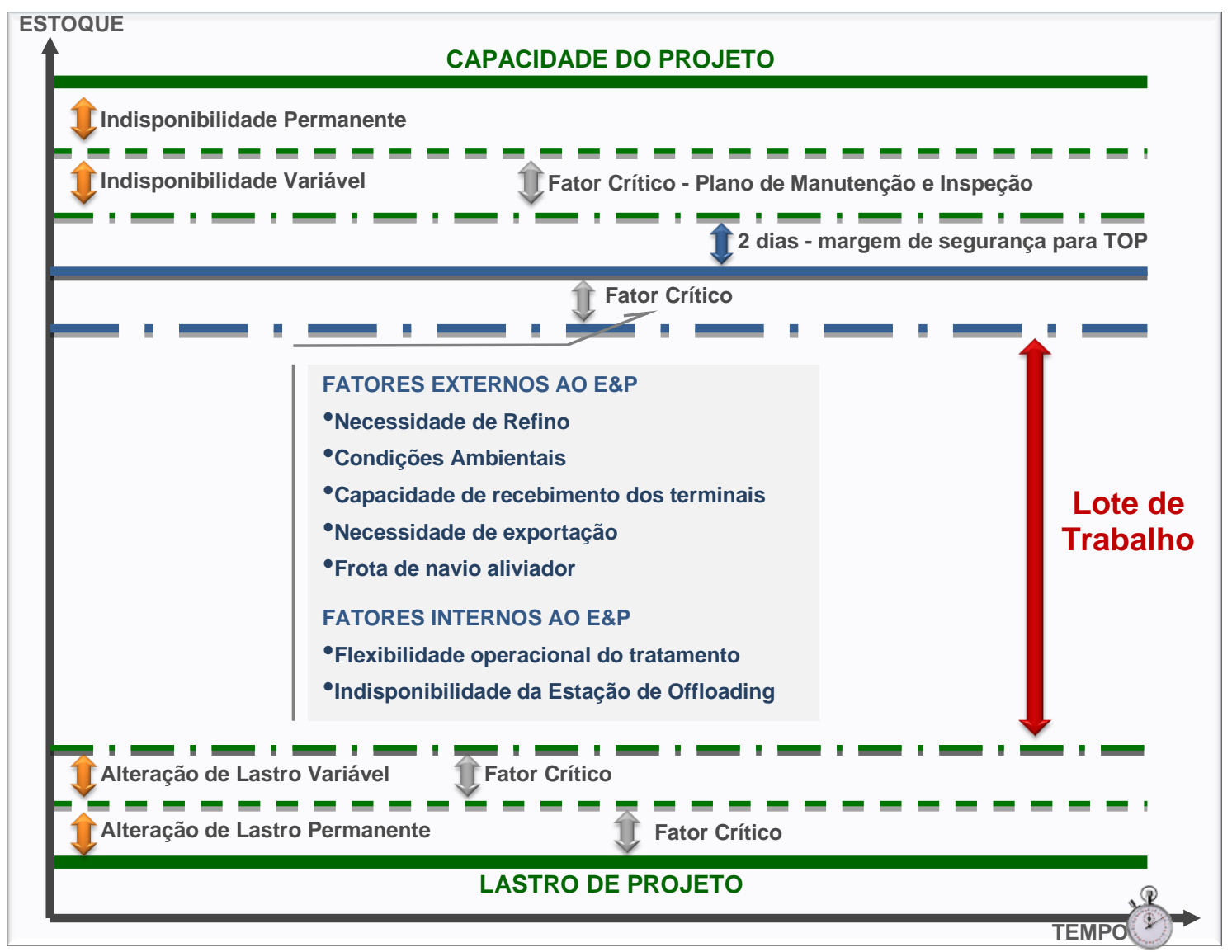

Figura 2 - Modelo Conceitual das Variáveis que influenciam os níveis de estoque nos F(P) SOS Fonte: O autor, (2012).

Abaixo são detalhadas as variáveis que influenciam os níveis de estoque dos $\mathrm{F}(\mathrm{P})$ SOs, detectadas no levantamento de informações, seus conceitos e algumas considerações:

- Capacidade de projeto: capacidade nominal de armazenagem do FPSO ou FSO;

- Indisponibilidade permanente de capacidade: redução da capacidade de armazenagem de forma permanente. Por ser um navio convertido em uma plataforma de produção de petróleo, diversos equipamentos e plantas de processamento são instalados nele, aumentando o peso da embarcação e impedindo a utilização de $100 \%$ da capacidade nominal de armazenagem, o que poderia comprometer a sua estabilidade, devido aos limites de esforços estruturais, podendo levá-lo a adernar;

- Indisponibilidade variável de capacidade: redução de capacidade de armazenagem devido à manutenção e inspeção dos tanques de carga da 
plataforma. Pelo fato do FPSO ou FSO ser um navio convertido em plataforma, o mesmo segue as normas da marinha brasileira, que diz que todos os tanques precisam ser inspecionados para avaliação e possível manutenção a cada cinco anos. Cada vez que um dos tanques entra em manutenção, o mesmo fica fora de operação, podendo acarretar no fechamento dos tanques laterais, caso necessite de algum reparo, para que não haja passagem de óleo de um tanque para o outro. Subtraindo-se as indisponibilidades permanente e variável da capacidade de projeto chega-se à capacidade operacional da plataforma em um dado momento. A variação da capacidade operacional de tancagem influencia diretamente o estoque médio da plataforma

- 2 dias de margem de seguranca para TOP: representa o volume referente a dois dias de produção da plataforma, condição atual para que o navio chegue antes da plataforma atingir a sua capacidade máxima, a partir da qual haveria a necessidade de fechamento de poços e redução de produção ou parada total da produção por falta de espaço. Este limite de dois dias é uma margem de segurança caso haja algum problema de mau tempo ou qualquer outro evento que impossibilite a operação de offloading;

- Necessidade de refino: retirada urgente de óleo devido a alguma necessidade de refino, como perda de carga em alguma refinaria devido à falta de um determinado tipo de óleo essencial para a produção de um determinado derivado;

- Condicões ambientais: necessidade de antecipação ou postergação de um offloading, devido à condição ambiental adversa, que impactará na impossibilidade da operação durante um determinado período;

- Capacidade de recebimento dos terminais: necessidade de postergação ou antecipação de um offloading, devido à impossibilidade do recebimento de óleo em um determinado terminal durante um determinado período como, por exemplo, manutenção de píer ou das linhas que interligam os píeres ao terminal;

- Necessidade de exportação: retirada urgente de óleo devido à necessidade de atendimento a um contrato de exportação. Geralmente as cargas de exportação são negociadas com dois meses de antecedência. Porém, caso haja algum problema operacional durante o carregamento, pode haver a necessidade de retirada de óleo de similar qualidade de outra plataforma, acarretando em seus níveis de estoque;

- Frota de navio aliviador: dependendo do tamanho e do perfil (tamanho dos navios) da frota de navios aliviadores, pode haver a necessidade de retirada de 
volumes maiores ou menores que os níveis considerados ideais, aumentando ou reduzindo o estoque médio da plataforma;

- Flexibilidade operacional do tratamento: o tratamento do óleo é feito através de plantas de processamento instaladas na superfície das plataformas de produção, e que têm por objetivo separar a água, o óleo e o gás produzidos no reservatório. O gás é escoado por gasoduto para terra; a água deve ser tratada e enquadrada de acordo com as especificações constantes na legislação ambiental para descarte em alto mar; e o óleo é armazenado nos tanques de carga da plataforma, para posterior transferência para o navio aliviador. Caso haja algum problema de desempenho neste processamento ou uma parada para manutenção da planta, o óleo é armazenado nos tanques de carga fora da faixa de especificação de qualidade no que se refere á característica de BSW (basic sediments and water), que é medido em percentual e significa a concentração de água e sedimentos emulsionados ao petróleo. Nestes casos, o óleo deve ficar armazenado durante um determinado tempo que, a depender do percentual de $B S W$, pode ser de um ou dois dias, para que a água seja decantada e armazenada no fundo do tanque, para posterior raspagem (remoção através da sucção efetuada por bombas) e movimentação para os tanques de água, até que o óleo seja especificado. Esta flexibilidade exige um determinado espaço de tancagem, reduzindo a capacidade de armazenagem de óleo e, conseqüentemente, reduzindo o estoque médio da plataforma;

- Indisponibilidade da estacão de offloading: impossibilidade da operação de offloading ocorrer num dado momento, seja por indisponibilidade dos equipamentos de offloading, como uma bomba ou um mangote, ou devido ao fato de haver uma operação que impeça a aproximação de outro navio simultaneamente, como numa operação de interligação de um poço à plataforma ou desconexão de um poço, quando há barcos de apoio atuando nas imediações da plataforma, pondo em risco as vidas das pessoas envolvidas;

- Lastro de projeto: volume de óleo ou água necessário para manter a sustentação e estabilidade do navio, de forma que o mesmo não aderne;

- Alteração de lastro permanente: alteração permanente do lastro em função da alteração do projeto original da plataforma, como instalação de uma planta de processamento ou de outro equipamento, que aumente o peso da plataforma e 
necessite de mudança no cálculo dos seus esforços estruturais e, consequentemente, alteração do lastro;

- Alteração de lastro variável: alteração em função da condição de mar ou em função da manutenção de tanques, situações em que se altera a configuração de esforços distribuídos na plataforma;

- Lote de trabalho: lote teórico de retirada de petróleo, levando em consideração todas variáveis descritas acima.

Das variáveis levantadas acima, foram priorizadas as que estão sob a gestão da área de Exploração e Produção, escopo deste trabalho, de modo a se efetuar uma análise de dados históricos do comportamento das plataformas. A partir daí, foi identificada a necessidade de acompanhar alguns indicadores que fossem capazes de apontar ineficiências operacionais nos processos de processamento, armazenagem e transferência do petróleo. Além disso, há necessidade de incorporar na previsão os eventos que influenciam diretamente na qualidade e no estoque do óleo.

\section{Processamento e Armazenagem do Óleo}

Atualmente existe um indicador que acompanha a qualidade do óleo apenas na transferência de custódia para o segmento Abastecimento, denominado índice de qualidade do petróleo entregue (IQPE), que é calculado através da seguinte fórmula:

IQPE = volume de óleo entregue dentro das especificações de qualidade (Eq. 11) Volume total de óleo entregue

Este indicador é acompanhado de forma corporativa e tem por objetivo garantir a entrega do óleo dentro das especificações acordadas entre as áreas de Exploração e Produção e de Abastecimento, para atendimento às necessidades das refinarias nacionais e aos contratos de exportação. A sua apuração se baseia nas medições de volume apurados no momento da transferência do petróleo da plataforma para o navio aliviador. 
Porém, não há um acompanhamento corporativo do desempenho do processamento do óleo produzido antes mesmo de sua armazenagem. Este desempenho é monitorado pelas plataformas, de modo a preparar o lote programado para transferência, buscando segregar o óleo enquadrado nas especificações de qualidade do óleo desenquadrado, considerado produto semiacabado, para que não haja contaminação do óleo que já está especificado.

Levando em consideração que um dos direcionadores da companhia é maximizar a produção de óleo, a produção não é reduzida em função da sua qualidade, mesmo quando há necessidade de manutenção das plantas de processamento, levando por vezes ao acúmulo temporário de óleo desenquadrado e/ou água nos tanques da plataforma. Estudos estão sendo realizados pelas áreas envolvidas para que sejam efetuados investimentos tanto em aumento da eficiência e confiabilidade das plantas de processamento das plataformas, quanto em infra-estrutura logística para escoamento e reprocessamento do óleo desenquadrado e escoamento, tratamento e descarte da água em terminais terrestres, navios específicos para tal objetivo ou outra solução logística.

De maneira geral, quando as plataformas acumulam óleo desenquadrado nos tanques de armazenagem, ações são tomadas para o seu enquadramento, através da decantação e raspagem da água. Porém, dependendo do tempo previsto para manutenção da planta de processamento e do tempo de armazenagem necessário para decantação da água, não é possível enquadrar o óleo armazenado devido ao limite da capacidade de armazenagem da plataforma. Neste caso, a plataforma deve informar à área corporativa esta situação, para que seja providenciada, junto ao segmento Abastecimento, a retirada de óleo desenquadrado para que não haja perda de produção por falta de espaço para armazenagem, trazendo impactos operacionais e custos indesejados para o restante da cadeia de suprimentos.

Por este motivo, é necessário acompanhar, corporativamente, tanto a qualidade do óleo produzido quanto a qualidade do óleo armazenado, de modo a antecipar ações que garantam a entrega do óleo nas especificações de qualidade, sem comprometer a sua produção. Além disso, é preciso também que os eventos que influenciam a qualidade do óleo ao longo do tempo, e que já tenham sido previstos no plano de manutenção dos equipamentos, sejam incorporados à 
previsão de qualidade e estoque do óleo, para que os tomadores de decisão tenham a visibilidade destas informações.

Em análise realizada com dados do índice de qualidade do petróleo entregue (IQPE) de todas as plataformas e a ocupação média da sua tancagem ao longo de 2011, observou-se que a tancagem de algumas plataformas está sendo ocupada por um volume muito alto de óleo desenquadrado e água em relação a sua capacidade operacional, mesmo atingindo $100 \%$ de IQPE, o que reforça a necessidade de acompanhamento da qualidade do óleo produzido e do óleo armazenado, além da incorporação dos eventos que influenciam a qualidade na previsão. Vale ressaltar que, em algumas situações, a entrega do óleo enquadrado tem um custo alto de sobreestadia de navio, que fica aguardando a especificação do óleo para a retirada do lote programado.

\section{Utilização da Capacidade Operacional}

Da mesma forma que a qualidade do óleo produzido e armazenado, a utilização da capacidade operacional é monitorada apenas pela plataforma, não havendo nenhum acompanhamento corporativo e de forma sistemática. Situações emergenciais são informadas à corporação quando não há alternativa senão o escoamento de óleo desenquadrado e/ou da água para evitar a perda de produção por falta de espaço para armazenagem do óleo.

Desta maneira, há necessidade de acompanhar de forma sistemática a utilização da capacidade de armazenagem, comparando a capacidade nominal com a capacidade útil da plataforma, de forma a identificar ações que possam maximizar a sua utilização. Aqui o fator crítico de sucesso é o planejamento das manutenções dos tanques. Além disso, é preciso também incorporar na previsão de estoques a alteração da capacidade de tancagem disponível da plataforma ao longo do tempo, pois quanto menor a tancagem, maior a freqüência de operações de alívio e maior a necessidade de navios na frota.

Através de um levantamento realizado sobre a utilização média da tancagem de todas as plataformas ao longo de 2011, observou-se que um número significativo de plataformas está com baixa capacidade útil de armazenagem, já que boa parte da sua capacidade nominal está sendo utilizada como lastro ou seus tanques estão em manutenção / inspeção, o que reforça a necessidade de 
acompanhamento desta variável, bem como a incorporação das alterações de capacidade de tancagem e de lastro na previsão.

\section{$\underline{\text { Transferência }}$}

As variáveis referentes ao processo de transferência de petróleo que influenciam os estoques das plataformas são a disponibilidade das estações de transferência e o lote de retirada. Cada um deles será detalhado a seguir.

Disponibilidade da Estação de Transferência (Offloading)

A estação de transferência pode estar indisponível devido à manutenção dos equipamentos do sistema de transferência ou por operações na plataforma que impeçam a operação, como conexão ou desconexão de poços.

Estes eventos são controlados pela plataforma, mas não corporativamente, de modo que se faz necessário incluí-los na previsão de eventos que influenciam os estoques das plataformas, com o objetivo de antecipar ou postergar as transferências em função destes eventos. Além disso, deve-se fazer um acompanhamento dos prazos estipulados para o retorno da manutenção, garantindo a disponibilidade do sistema de maneira adequada.

Vazão da Bomba de Transferência

Apesar de fazer parte do sistema de transferência citado no item anterior, a vazão está sendo aqui destacada, visto que a mesma pode variar de acordo com a eficiência da bomba de transferência e influencia diretamente no tempo da operação de offloading, incorrendo em custos adicionais para a companhia caso a operação exceda o limite previsto de tempo, o que chamamos de sobreestadia. Além disso, esta variável influencia o nível de estoque da plataforma. Como as plataformas possuem mais de uma bomba e, por vezes, uma delas está em manutenção, faz-se necessário também o acompanhamento do seu plano de manutenção, garantindo a sua disponibilidade de maneira adequada.

Através de um levantamento realizado junto às plataformas ao longo de 2011, com dados de tempo de estadia dos navios durante a operação de 
transferência e os volumes carregados, chegou-se a vazão efetiva média das operações. Esta vazão foi comparada com a capacidade operacional e com a capacidade de projeto das bombas de transferência e observou-se que, em grande parte das plataformas, há uma diferença muito elevada entre estas vazões. Vale ressaltar que a vazão efetiva pode não refletir exatamente a vazão da bombeio da operação, pois podem ocorrer interrupções no bombeio por outros motivos como, por exemplo, condições do mar adversas. O estudo destacou o tempo de redução superior a 10 horas em algumas plataformas caso a vazão efetiva fosse igual à capacidade operacional, lembrando que o limite de estadia do navio é de 36 horas, a partir do qual começa a ser cobrado um adicional de sobreestadia. Este tipo de análise deve ser sistematizado de forma a garantir um melhor desempenho das operações e, consequentemente, redução de custos com sobreestadia.

Lote de Retirada

Outro estudo realizado com dados de 2011 comparou o lote máximo de retirada de petróleo das plataformas (calculado a partir da capacidade operacional de tancagem, subtraindo-se dois de produção, que correspondem à margem de segurança, e o lastro) com o lote médio efetivamente retirado. Estes dados foram comparados também com as capacidades dos diferentes tipos de navio e observou-se que os lotes não estão sendo otimizados, já que estão sendo carregados lotes menores que as capacidades dos navios. Concluiu-se, a partir deste levantamento, a necessidade de prever os lotes de óleo disponível, de modo a maximizar as suas retiradas, e acompanhar as operações de maneira sistemática, com o objetivo de detectar desvios e definir ações de melhoria.

\section{2}

\section{Necessidades de Melhoria}

Baseado no diagnóstico exposto e no quadro resumo do diagnóstico da situação atual das variáveis que estão sob a gestão da área de Exploração e Produção, apresentado na Tabela 8 , são indicadas as seguintes melhorias necessárias: 
- elaborar uma projeção de estoque de óleo disponível com horizonte de dois meses, incorporando não somente a variável qualidade na previsão de produção como as variações diárias da produção ao longo do mês, proporcionando uma previsão diária ao invés de uma média mensal. Além destas variáveis, deverão ser consideradas e previstas as variações da capacidade de armazenagem, do lastro, da disponibilidade dos sistemas de offloading e da vazão de bombeio das plataformas, conforme apresentado na Tabela 8. Esta projeção deverá ser enviada mensalmente para a área de Abastecimento em substituição ao envio atual da Estimativa Trimestral de Produção, com o objetivo de melhorar a qualidade da informação necessária para os processos de programação das importações e exportações de petróleo e do escoamento da produção nacional.

Tabela 8 - Quadro Resumo do Diagnóstico da Situação Atual das Variáveis sob gestão do E\&P

\begin{tabular}{|c|c|c|c|}
\hline Área de Atuação & Variável & $\begin{array}{l}\text { Fator Crítico de Sucesso } \\
\text { (eventos previsíveis) }\end{array}$ & $\begin{array}{c}\text { Acompanhamento } \\
\text { Corporativo? }\end{array}$ \\
\hline Produção & Volume produzido & $\begin{array}{l}\text { - Paradas programadas para manutenção de } \\
\text { equipamentos de produção } \\
\text { - Entrada e saída de poço }\end{array}$ & SIM \\
\hline \multirow{2}{*}{ Qualidade } & $\begin{array}{l}\text { Qualidade do óleo } \\
\text { produzido / em estoque }\end{array}$ & \multirow{2}{*}{$\begin{array}{l}\text { - Paradas programadas para manutenção de } \\
\text { equipamentos da planta de tratamento de óleo }\end{array}$} & NÃO \\
\hline & $\begin{array}{c}\text { Qualidade do óleo } \\
\text { entregue }\end{array}$ & & SIM \\
\hline \multirow{2}{*}{ Armazenagem } & Capacidade disponível & \multirow{2}{*}{ - Plano de manutenção e inspeção de tanques } & NÃO \\
\hline & Lastro & & NÃO \\
\hline \multirow{3}{*}{ Transferência } & $\begin{array}{l}\text { Disponibilidade dos } \\
\text { sistemas de offloading }\end{array}$ & $\begin{array}{l}\text { - Paradas programadas para manutenção de } \\
\text { equipamentos do sistema de offloading } \\
\text { - Conexão / desconexão de poço }\end{array}$ & NÃO \\
\hline & $\begin{array}{l}\text { Vazão de bombeio } \\
\text { operacional }\end{array}$ & $\begin{array}{l}\text { - Paradas programadas para manutenção da } \\
\text { bomba }\end{array}$ & NÃO \\
\hline & Lote de Retirada & Depende das demais variáveis & NÃO \\
\hline
\end{tabular}

Fonte: O autor, (2012).

- sugerir, na projeção dos estoques, as datas e os lotes para a retirada do óleo, levando em consideração a análise de trade-off entre o custo de oportunidade do capital referente ao óleo armazenado e os custos de transporte marítimo;

- elaborar uma projeção de estoque de óleo disponível com horizonte de uma semana, com as mesmas informações da projeção de dois meses, citada no item anterior, com o objetivo de melhorar a programação de navios realizada no curtíssimo prazo. Esta projeção deverá ser enviada diariamente para a área de Abastecimento em substituição à utilização do sistema SITOP para este fim; 
- acompanhar corporativamente os fatores críticos de sucesso de cada variável que influencia os estoques dos $\mathrm{F}(\mathrm{P}) \mathrm{SOs}$ apresentados na Tabela 8 e o próprio nível de estoque, a partir da elaboração e acompanhamento de indicadores de desempenho;

- analisar os indicadores de desempenho e propor ações de melhoria para o processo como um todo, envolvendo todas as áreas de atuação: produção, qualidade, armazenagem e transferência;

- desenvolver uma ferramenta de suporte à decisão para auxiliar na projeção de estoques e na determinação dos lotes de retirada, utilizando um tratamento estocástico, levando em conta as incertezas associadas aos processos de produção, processamento (qualidade), armazenagem e transferência e sua natureza aleatória. Esta ferramenta poderá ter suas variáveis de entrada modificadas para simular diversos cenários de eventos aleatórios, de modo que seja capaz de capturar a natureza estocástica do processo e sua complexidade.

- buscar maior integração com a área de Abastecimento da empresa, tanto no que diz respeito às programações de navios para escoamento da produção quanto no planejamento dos estoques de petróleo da companhia e no planejamento da frota de navios aliviadores da produção;

Através da implantação das melhorias descritas acima, espera-se alcançar os seguintes benefícios:

- minimizar risco de perda de produção das plataformas por falta de espaço para armazenagem;

- minimizar risco de entrega de óleo desenquadrado (considerado produto semiacabado) e/ou água para os terminais e refinarias;

- melhorar programação de navios (indicador IAPA);

- melhorar atendimento às cargas de exportação; 
- melhorar a eficiência operacional do processamento do óleo;

- melhorar a utilização da tancagem;

- aumentar a disponibilidade dos sistemas de offloading;

- gerir os custos financeiros do estoque;

- maior utilização da capacidade dos navios e, consequentemente, redução de praça morta;

- redução de custos com sobreestadia;

- gestão integrada e otimizada dos estoques de petróleo da companhia;

- melhor dimensionamento e otimização da frota de navios aliviadores da produção;

Para se implantar todas as melhorias descritas acima, entende-se necessária a criação de um processo integrado de gestão de estoques, onde todas as informações necessárias ao processo estariam disponíveis e estruturadas em bancos de dados e sistemas compartilhados pelas duas áreas de negócio, com a utilização de ambientes colaborativos, onde especialistas de cada um dos processos trabalhariam juntos utilizando simuladores de alta tecnologia e desempenho, tomando decisões baseadas em variáveis probabilísticas e análises de risco, levando em consideração também os custos de cada decisão. No entanto, há que se considerar que cada área está num estágio diferente de maturidade em relação ao processo de gestão de estoques.

Pelo exposto acima, e tendo em vista o escopo do trabalho aqui proposto, para atender a maioria das melhorias necessárias será desenvolvido e se dará início à implantação de um novo processo aqui denominado de Gestão de Estoques das Unidades Marítimas de Armazenagem e Escoamento de Petróleo. Este processo será desenvolvido e implantado na área de Exploração e Produção levando em consideração as suas interfaces e, após atingir um grau de maturidade 
considerado adequado, deverá ser integrado ao processo atual existente no segmento Abastecimento-Logística.

Este processo deverá ser mapeado de acordo com uma metodologia de desenho de processos reconhecida no mercado, sendo apresentados os seus macroprocessos, processos e fluxogramas das atividades. 


\section{Desenvolvimento do Processo de Gestão de Estoques das Unidades Marítimas de Armazenagem e Escoamento de Petróleo}

$\mathrm{O}$ processo de gestão de estoques aqui delineado tomou por base a definição de Ching (2006, p. 33), que entende por gestão de estoques o planejamento do estoque, seu controle e sua retroalimentação sobre o planejamento, definição esta já apresentada na revisão bibliográfica (capítulo 2).

\section{$\underline{\text { Planejamento do Estoque: }}$}

De acordo com Ching (2006, p. 33),

[...] o planejamento consiste na determinação dos valores que o estoque terá com o decorrer do tempo, bem como na determinação das datas de entrada e saída dos materiais em estoque e na determinação dos pontos de pedido de material.

Este planejamento corresponde, dentro do processo aqui definido, à etapa de projeção dos estoques, onde será selecionado o melhor cenário de projeção. O melhor cenário de projeção não determinará o nível de produção (entrada no estoque) das plataformas, mas definirá os seus níveis ideais de estoque ao decorrer do horizonte da previsão (dois meses) e as datas para escoamento da produção pelos navios aliviadores.

Para se chegar à projeção dos estoques e do escoamento da produção, serão coletados dados históricos de produção, estoque e qualidade, bem como dados determinísticos de eventos projetados para os próximos dois meses, para posterior consolidação e análise, utilizando-se técnicas de tratamento estatístico de dados para previsão dos estoques. Posteriormente, os estoques e o escoamento da produção de petróleo serão projetados considerando-se diferentes cenários de retirada de acordo com o porte do navio aliviador, sendo definido o melhor cenário de acordo com a decisão da companhia em relação aos níveis de estoque em que se deseja trabalhar no período seguinte, que pode ser manter, reduzir ou elevar os estoques, e levando em consideração as seguintes premissas: 
- maximizar produção de óleo é prioridade. Ou seja, o escoamento não pode definir o nível da produção e sim o contrário, a produção é que deve determinar o nível de escoamento. As projeções indicarão a necessidade de retirada para garantir a continuidade operacional, minimizando o risco de parada de produção por falta de escoamento;

- é necessário garantir qualidade adequada para refino nacional e exportação. As projeções levarão em consideração o escoamento apenas do óleo especificado e não levarão em consideração as retiradas de óleo desenquadrado (considerado produto semi-acabado) nem da água, salvo situações emergenciais já programadas. O objetivo é identificar situações de risco de envio de óleo desenquadrado ou de água para manter a produção de óleo e atuar preventivamente para que estes eventos indesejados não ocorram;

- análise comparativa do custo mínimo total (custo de oportunidade do capital investido no estoque + custo de transporte). Serão feitas projeções considerando os diferentes portes de navio aliviador e analisando, para cada um deles, o custo total das operações, de forma a definir o lote ideal de retirada, baseado no custo mínimo total.

Mesmo após a decisão do cenário de projeção de estoques para envio à área de Abastecimento-Logística da empresa, para que sejam planejadas as cargas de importação e exportação e programados os navios para a retirada do petróleo, poderão ser simulados diferentes cenários, com dados operacionais atualizados diariamente a fim de ajustar e dar maior robustez à programação, através de análises de risco e de sensibilidade, por exemplo.

\section{Controle do Estoque:}

Ainda de acordo com Ching (2006, p. 33), "o controle consiste na determinação dos dados reais, correspondentes aos planejados mencionados”.

O controle será realizado através do acompanhamento e registro diário da produção, estoque e qualidade do óleo produzido e armazenado nas plataformas; da disponibilidade e utilização da tancagem; das operações de transferência; e das projeções diárias com horizonte de sete dias. Estes dados serão utilizados para a apuração dos indicadores, na etapa seguinte do processo. 
Retroalimentação:

A retroalimentação é a comparação dos dados de controle com os dados do planejamento, a fim de constatar seus desvios e determinar suas causas. Quando for o caso, a empresa deve corrigir o plano para torná-lo mais realista, fazendo com que o planejamento e o controle sejam cada vez mais coincidentes (CHING, 2006, p. 33).

Após a apuração mensal dos indicadores, serão realizadas reuniões de análise crítica do processo com todos os envolvidos, de modo a identificar as causas dos desvios e as oportunidades de melhoria e propor ações para as causas e oportunidades identificadas no processo como um todo.

O horizonte do planejamento tático ideal identificado é de dois meses de visão, para que haja tempo hábil para a programação adequada das cargas de exportação e para reagir a qualquer nova demanda ou alteração da demanda de refino ou de exportação durante o período projetado.

\section{1}

\section{Padrão de Estruturação do Processo}

Para representar o processo, seguiremos um padrão de mercado reconhecido e adotado mundialmente para a definição e estruturação de processos e sub-processos segundo a formatação do Bussiness Proccess Management (BPM), abrangendo até o nível 3, de atividades. Faz-se importante ressaltar que não está no escopo deste trabalho o mapeamento das atividades transacionais que derivariam no mapeamento do nível 4, de procedimento operacional. Apresentamos, através da Figura 3, um exemplo para melhor entendimento deste padrão: 


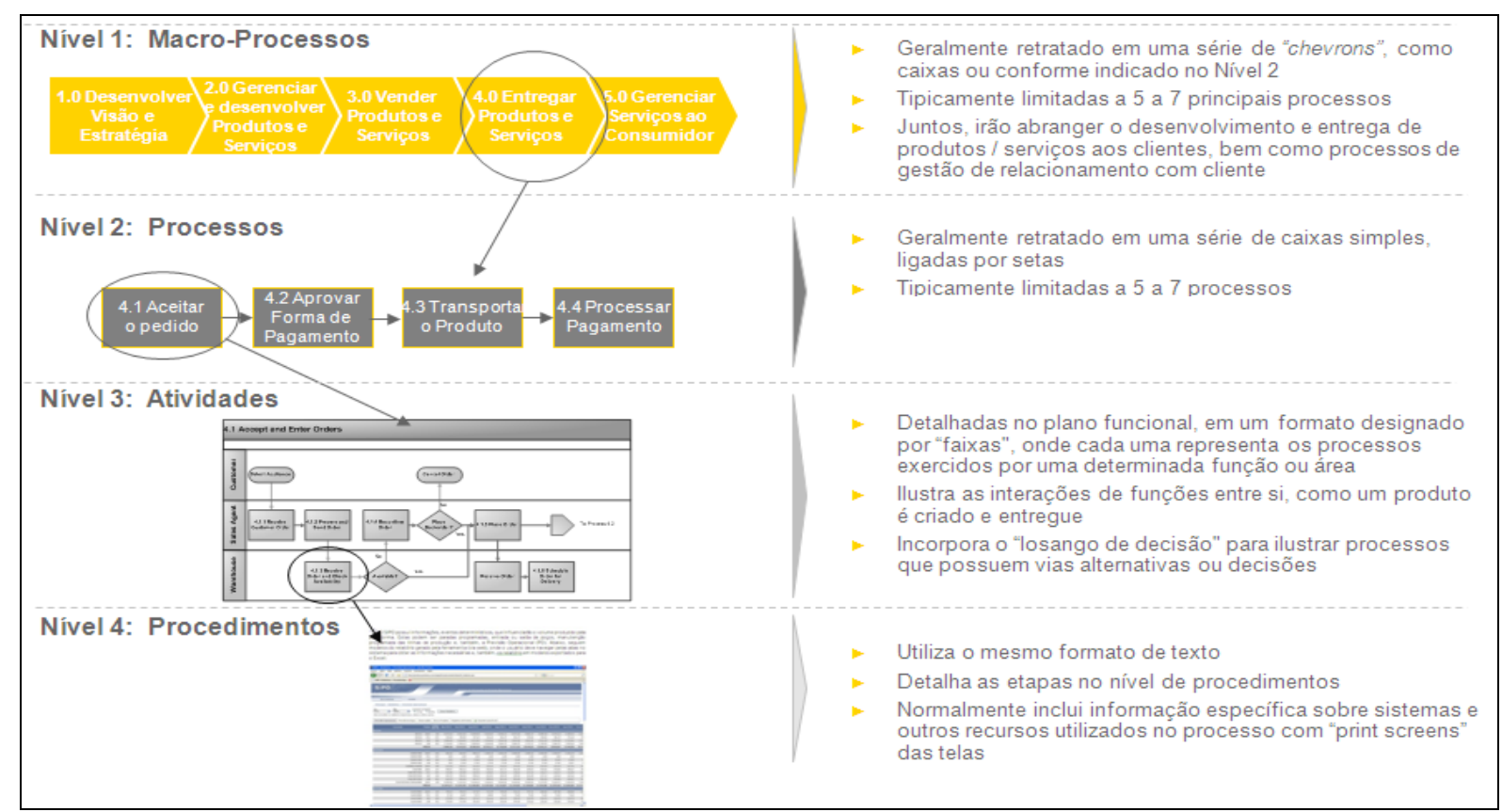

Figura 3 - Padrão BPM de Mapeamento de Processo Fonte: O Autor, (2012).

É apresentado através da Figura 4 o padrão de legenda adotado e recomendado pelo padrão BPM para mapeamento do fluxograma de atividades (nível 3) e que será utilizado para este trabalho.

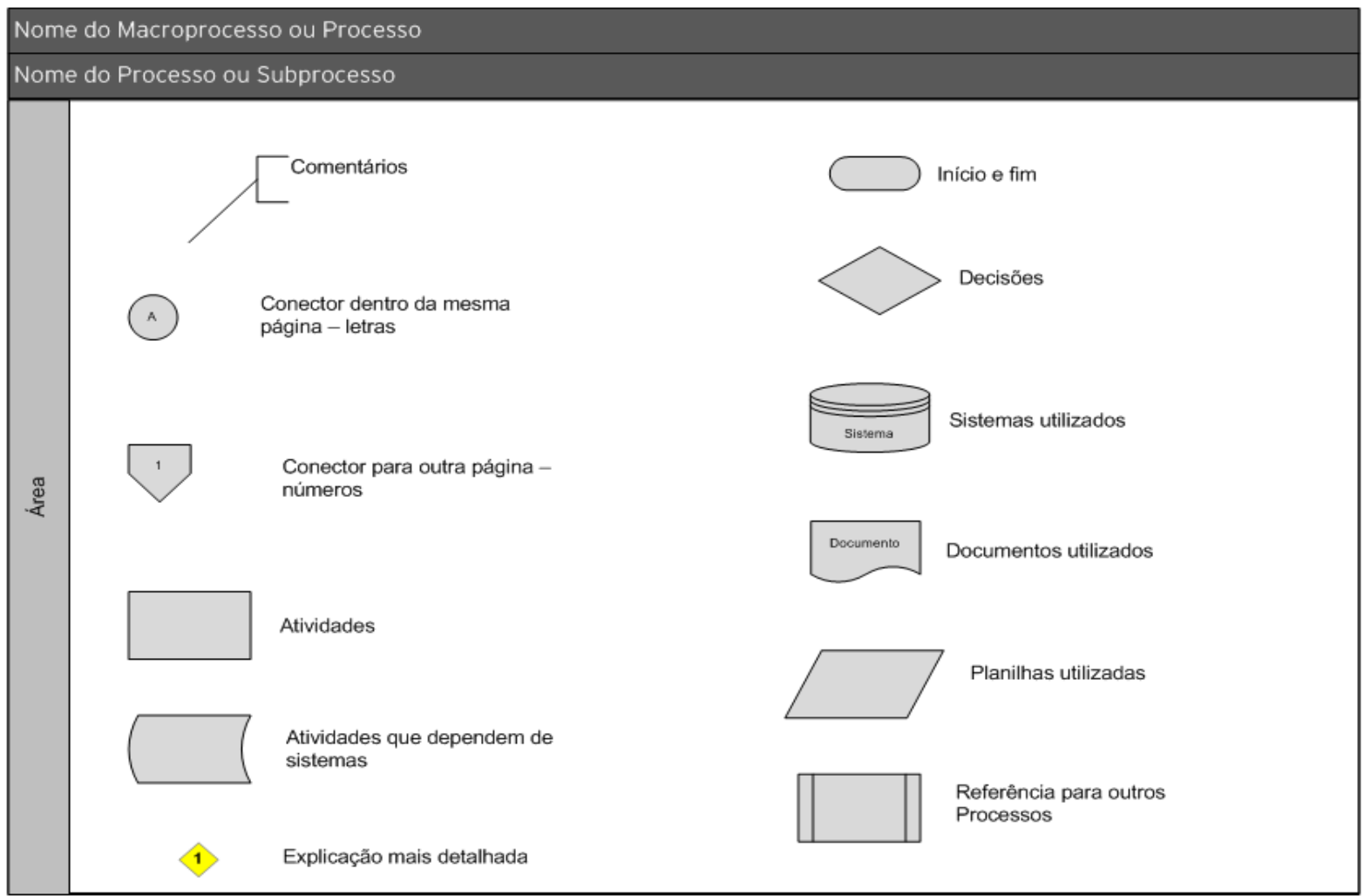

Figura 4 - Padrão BPM de Mapeamento de Processo (Legenda de fluxos) Fonte: O Autor, (2012). 
4.2

\section{Desenvolvimento do Processo de Gestão de Estoques}

Seguindo o padrão BPM, o processo de gestão de estoques de petróleo está estruturado de acordo com o seguinte encadeamento de macroprocessos e processos, representado através da Figura 5. Cada macroprocesso (nível 1) foi subdividido em processos (nível 2) e para cada um dos processos foi desenhado um fluxograma de atividades (nível 3).

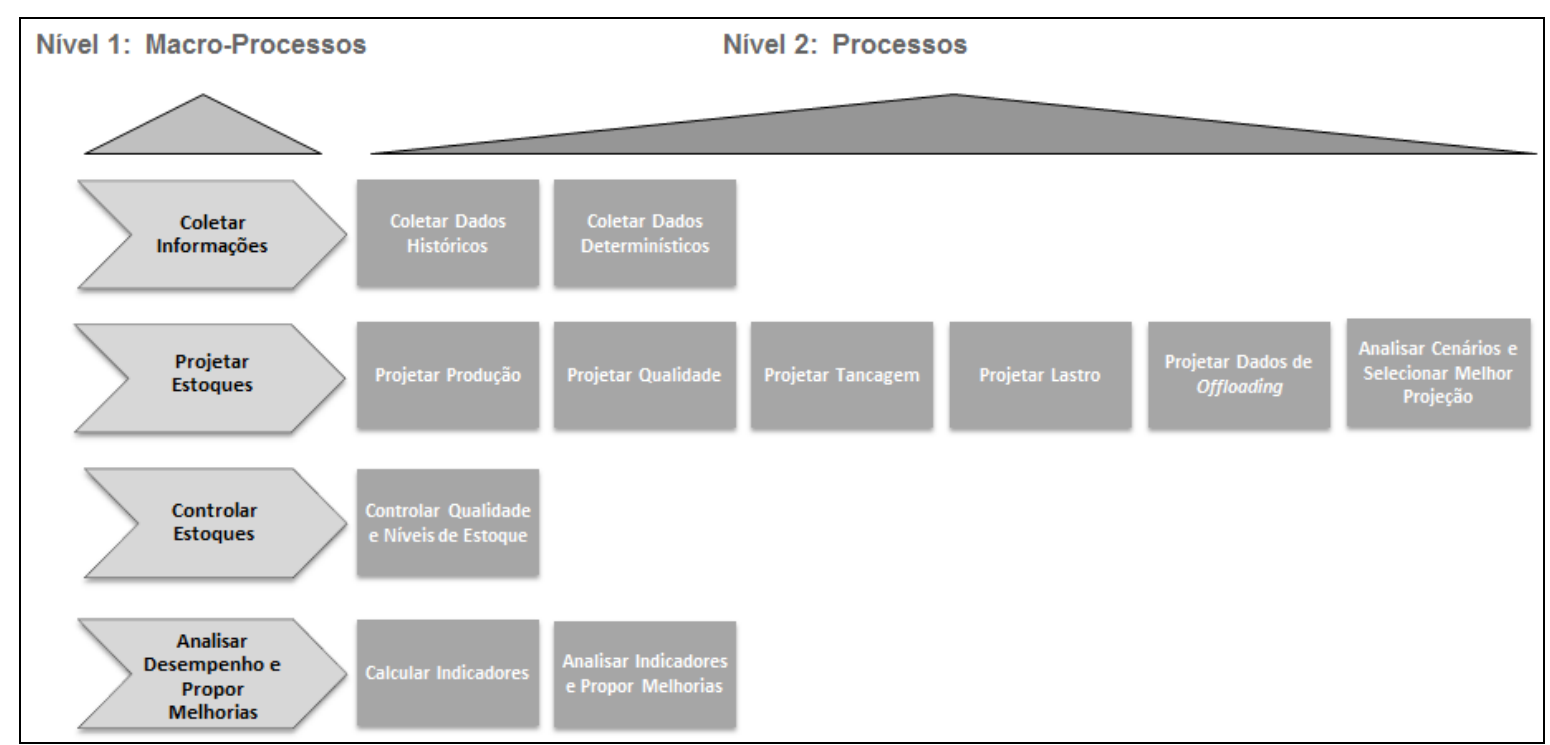

Figura 5 - Macro-Processos e Processos de Gestão de Estoques Fonte: O autor, (2012).

Através da Figura 6 é apresentado o macroprocesso "Coletar Informações", indicando os processos que o compõem. $\mathrm{Na}$ fase de desenvolvimento deste macroprocesso foi identificada a necessidade de criação de novos fluxos de informações, que serão apresentados adiante juntamente com o detalhamento de cada um dos seus processos.

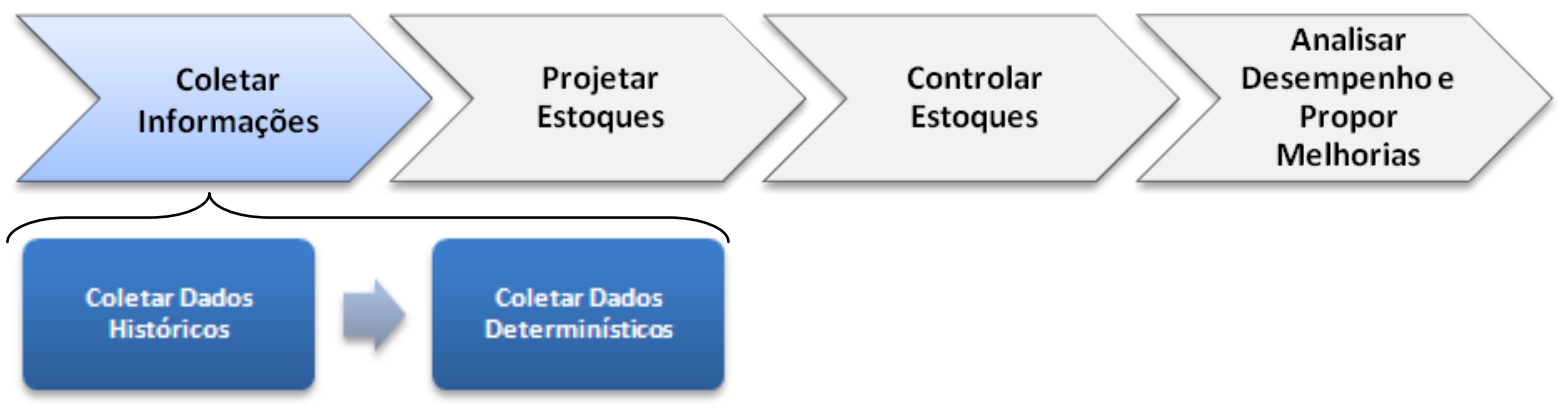

Figura 6 - Detalhamento do Macroprocesso "Coletar Informações" Fonte: O autor, (2012). 


\subsection{1}

\section{Coletar Informações}

Este macroprocesso consiste em coletar os dados históricos de produção e qualidade, bem como eventos determinísticos de produção, qualidade, tancagem, lastro e transferência, que influenciam diretamente os níveis de estoque das plataformas, para que todas as informações necessárias ao processo de gestão de estoques sejam consolidadas e analisadas na etapa seguinte. Como será detalhado adiante, a maioria destas informações não estava disponível de forma estruturada, e foi necessária a criação de novos fluxos de informações para que as mesmas fossem disponibilizadas de maneira adequada à necessidade do trabalho.

Em seguida, é apresentado cada um dos processos que compõem o macroprocesso "Coletar Informações", os novos fluxos de informações e o detalhamento de cada um destes processos com o respectivo fluxograma das suas atividades.

\subsubsection{1}

\section{Coletar Dados Históricos}

Este processo consiste em coletar os dados históricos de produção e qualidade necessários para a projeção de estoques na etapa seguinte. Como estas informações não estavam disponíveis de forma estruturada, foi necessária a criação de um novo fluxo de informações para que as mesmas fossem disponibilizadas de maneira adequada à necessidade do trabalho. Para cada uma destas informações, será resumida a sua utilização na projeção.

\section{Dados de Produção:}

- dados históricos da produção bruta (óleo + água emulsionada) realizada: poderão ser utilizados para projetar os volumes produzidos através do seu tratamento estatístico, baseando-se nos modelos constante ou linear de previsão de demanda, sendo utilizados os métodos de amortecimento exponencial simples ou duplo, apresentados na revisão bibliográfica (capítulo 2), a depender do estágio do ciclo 
de vida da produção do reservatório. Além disso, estas informações serão utilizadas para calcular os indicadores de desempenho relacionados à produção.

Dados de Qualidade:

- Dados históricos de estoque de óleo, por classificação de qualidade (baseado no teor \% de BSW), e da água: para auxiliar a projetar os estoques de óleo, de acordo com a sua qualidade, e da água, para os dois meses seguintes, após modelagem do comportamento dos estoques. Além disso, estas informações servirão para calcular os indicadores de desempenho relacionados à qualidade. Abaixo segue exemplo, através da Tabela 9, dos dados históricos de qualidade que deverão ser coletados.

Tabela 9 - Exemplo de Estoque de Óleo, em função da Qualidade, e de Água

\begin{tabular}{|c|c|c|c|c|c|}
\hline & \multicolumn{4}{|c|}{ Estoque de Acordo com a Qualidade $\left(\mathrm{m}^{3}\right)$} & \\
\hline Estoque Total $\left(\mathrm{m}^{3}\right)$ & $\begin{array}{c}\text { Óleo com BSW } \\
\text { até } 0,5 \% \\
\end{array}$ & \begin{tabular}{|l|} 
Óleo com BSW \\
entre $0,5 \%$ e $1 \%$ \\
\end{tabular} & \begin{tabular}{|l|} 
Óleo com BSW \\
entre $1 \%$ e $5 \%$
\end{tabular} & Óleo com BSW acima de $5 \%$ & $\begin{array}{c}\text { Estoque de Água } \\
\left(\mathrm{m}^{3}\right)\end{array}$ \\
\hline 150.000 & 35.000 & 50.000 & 30.000 & 20.000 & 15.000 \\
\hline
\end{tabular}

Fonte: O autor, (2012).

Conforme mencionado no capítulo 3.2 (Necessidades de Melhoria) foi identificada a necessidade da criação de um fluxo diário de informações da área de E\&P para a área do Abastecimento-Logística com o objetivo de melhorar a programação de navios realizada no curtíssimo prazo, em substituição à utilização do sistema SITOP.

De forma a conciliar a demanda de informações históricas de produção e de qualidade e a necessidade do fluxo de informações mencionado acima para atender à programação de curtíssimo prazo, foi criado um novo fluxo de informações que atendesse ambas as demandas.

Neste novo fluxo de informações, o estoque e a qualidade do óleo e o estoque da água são projetados diariamente, com um horizonte de sete dias, baseados nas previsões mais atuais de produção dos poços e na eficiência do processamento do óleo e da água; além de informações como espaço disponível de tancagem para recebimento da produção, necessário para prever o tempo em que a plataforma poderá receber e armazenar o óleo produzido, sem precisar reduzir ou parar a produção, baseado em informações de capacidade disponível de 
tancagem, em função do plano de manutenção e inspeção dos tanques de carga; e outra informação importante é a condição operacional dos equipamentos que compõem os sistemas de transferência, que influem diretamente no tempo da operação de transferência do óleo e, em alguns casos, impossibilitam a operação em um determinado período, como no caso de manutenção de uma bomba, por exemplo.

A melhor maneira de coletar diariamente tais informações, oriundas das plataformas, foi através da criação de um novo boletim, denominado de Planejamento da Retirada de Petróleo (PRP), similar aos demais boletins mencionados no capítulo 3.1 (Diagnóstico da Situação Atual), que são migrados para o sistema SINP-BC.

De forma a disponibilizar tais informações, oriundas do SINP-BC, da forma mais amigável possível, foi desenvolvida uma interface web denominada WEBEP, a partir da qual as informações do boletim PRP são enviadas diariamente para o banco de dados corporativo da área de Abastecimento, como insumo do processo de programação de navios no curtíssimo prazo.

O fluxograma apresentado através da Figura 7 detalha o novo fluxo de informações e as atividades do processo "Coletar Dados Históricos", que é explicado em seguida.

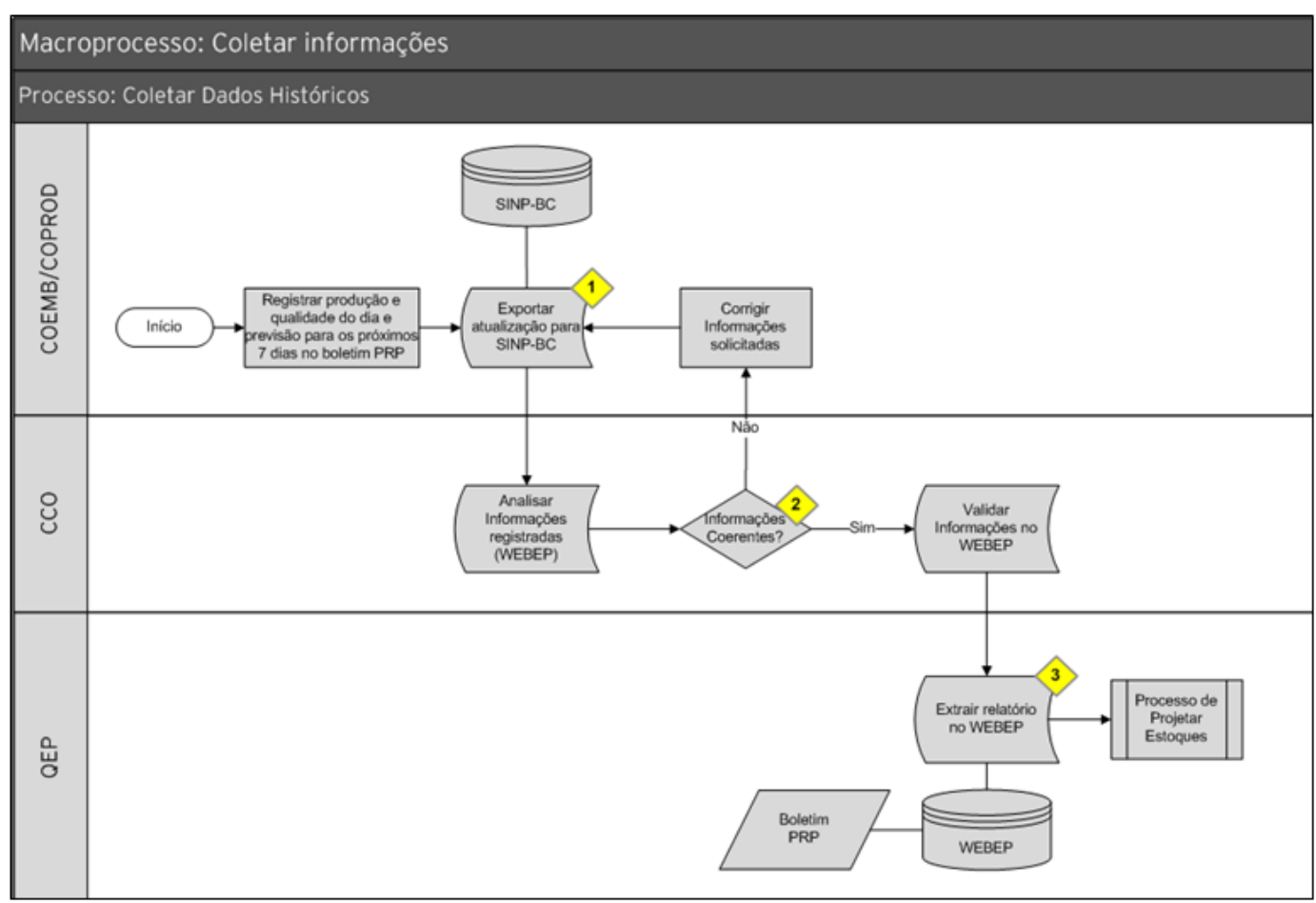

Figura 7 - Fluxograma do processo "Coletar Dados Históricos" Fonte: O autor, (2012). 
COEMB (coordenador da embarcação da plataforma) ou COPROD (coordenador de produção da plataforma) deve registrar a produção e a qualidade do óleo armazenado e as suas projeções diárias para os sete dias seguintes no Boletim PRP, que posteriormente são exportadas para o sistema SINP-BC (sistema de informação de produção da Bacia de Campos). Após essa atualização, o sistema WEBEP importa automaticamente as informações do SINP-BC, ficando também atualizado.

O CCO (Centro de Controle Operacional) deve analisar as informações fornecidas pelas plataformas e validá-las, através do sistema WEBEP. Caso existam incoerências, o CCO deve solicitar ao COEMB/COPROD da respectiva plataforma as correções necessárias, reiniciando o processo.

A gerência de Qualidade e Estoque de Produtos (QEP) deve extrair um relatório do sistema WEBEP com as informações do boletim PRP, já validadas pelo CCO. É exemplificado, através da Figura 8, o relatório da plataforma P-31, cujas informações de produção e qualidade estão destacadas em vermelho.

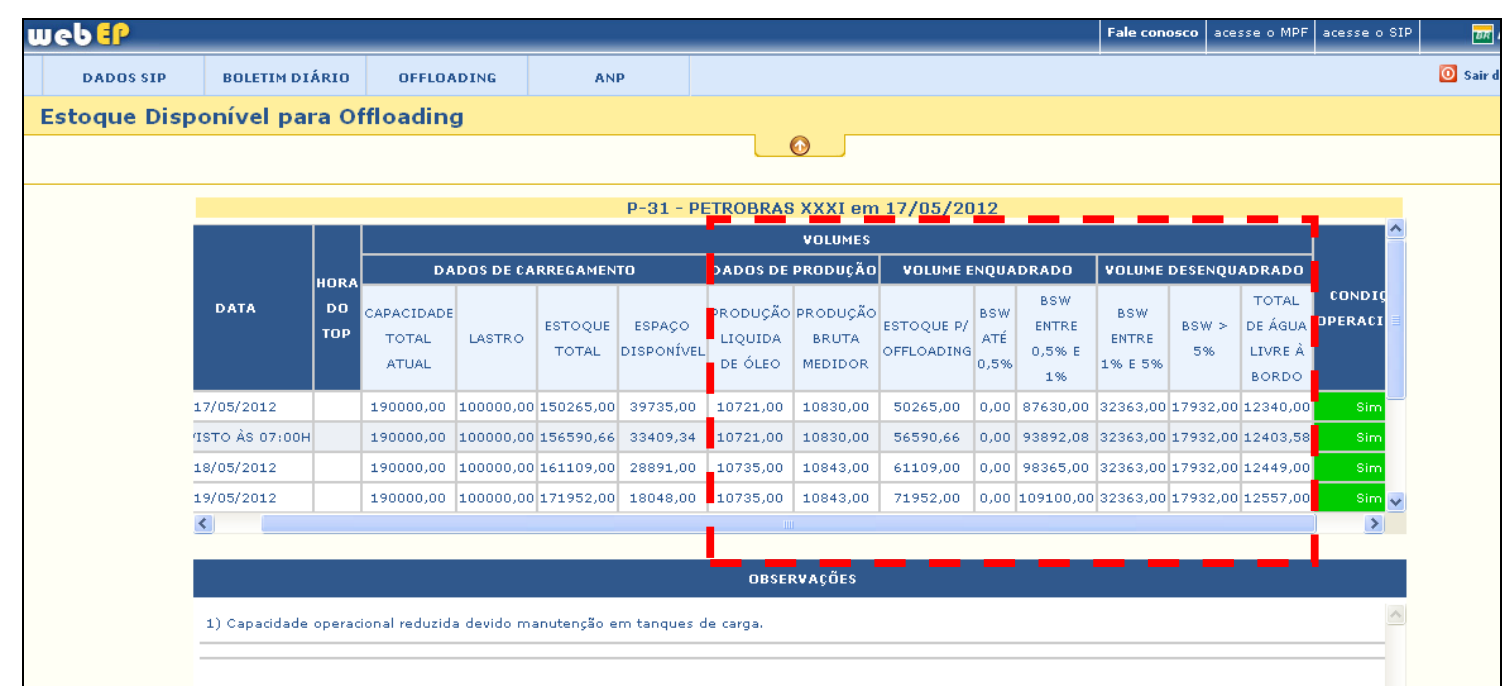

Figura 8 - Tela de Consulta do Boletim PRP no sistema WEBEP com dados fictícios Fonte: O autor, (2012). 


\subsubsection{2}

Coletar Dados Determinísticos

Este processo consiste em coletar os dados determinísticos de produção, qualidade, tancagem, lastro e offloading necessários para a projeção de estoques na etapa seguinte. Como a maioria destas informações não estava disponível de forma estruturada, foi necessária a criação de um novo fluxo de informações para que as mesmas fossem disponibilizadas de maneira adequada à necessidade do trabalho.

Serão apresentadas, primeiramente, as informações que já estavam disponíveis e estruturadas, visto que as mesmas já faziam parte de rotinas existentes. Para cada uma das informações, será resumida a sua utilização na projeção.

\section{Dados Determinísticos de Produção:}

- Previsão de Produção do sistema SIPO: previsão da média mensal da produção diária (m3/dia) para os três meses seguintes, registrada na Estimativa Trimestral, conforme exemplo apresentado através da Tabela 10, além dos eventos determinísticos já cadastrados mensalmente neste sistema, como a previsão de paradas programadas, apresentado como exemplo na Tabela 11, e previsão de entrada ou saída de poços, apresentados na Tabela 12, ambas as previsões com datas de início e fim de cada evento e os volumes que influenciarão a produção neste período. Estas informações poderão ser utilizadas para calcular a projeção da produção diária.

Em seguida são apresentados os dados determinísticos que ainda não estavam disponíveis de forma estruturada e para o que houve a necessidade da criação de um novo fluxo de informações. 
Tabela 10 - Exemplo Fictício de Previsão da Média Mensal da Produção Diária

\section{SISTEMA DE INFORMAÇÕES DA PREYISÃ̃ OPERACIONAL - SIPO ESTIMATIYa TRIMESTRAL DE PRODUÇÃo DE ÓlEo POR CORRENTE ESCOAMENTO}

Data de Referência: 01/07/2012

Valores Apresentados em: m3/dia

\begin{tabular}{|c|c|c|c|}
\cline { 2 - 4 } \multicolumn{1}{c|}{ Corrente } & jul/2012 & ago/2012 & set/2012 \\
\hline ALBACORA LESTE P-50 & $7.293,16$ & $8.441,70$ & $8.305,83$ \\
\hline BARRACUDA - P-43 & $13.615,72$ & $14.196,44$ & $12.178,71$ \\
\hline CARATINGA - P-48 & $14.585,35$ & $13.784,07$ & $13.226,25$ \\
\hline MARLIM FPSO-MLS & $5.054,66$ & $5.032,84$ & $4.971,79$ \\
\hline MARLIM LESTE FPSO-CIDADE DE NITERÓl & $3.297,79$ & $7.317,12$ & $7.099,16$ \\
\hline MARLIM LESTE P-53 & $13.015,55$ & $12.665,82$ & $10.357,86$ \\
\hline MARLIM SUL - P-40 & $9.943,40$ & $9.809,23$ & $9.864,45$ \\
\hline MARLIM SUL - P-56 & $17.767,03$ & $18.797,58$ & $19.621,91$ \\
\hline RONCADOR - P-52 & $21.134,80$ & $9.935,31$ & $20.199,47$ \\
\hline RONCADOR - P-54 & $15.240,04$ & $15.321,11$ & $15.089,46$ \\
\hline RONCADOR BRASIL MISTURA & $5.027,70$ & $5.478,73$ & $5.372,03$ \\
\hline
\end{tabular}

Fonte: O autor, (2012).

Tabela 11 - Exemplo Fictício de Previsão de Paradas Programadas

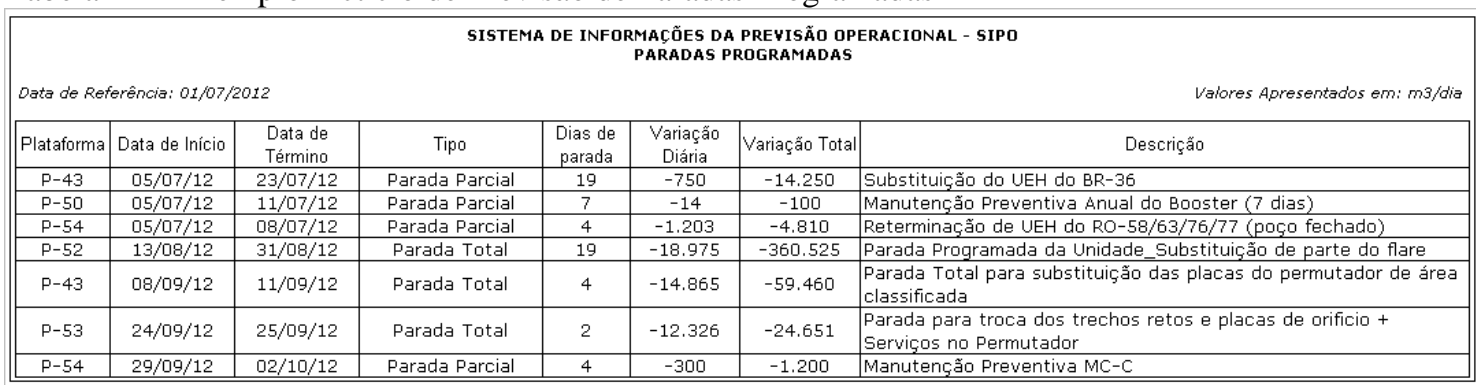

Fonte: $\mathrm{O}$ autor, (2012).

Tabela 12 - Exemplo Fictício de Previsão de Novos Projetos - Entrada de Poços

\begin{tabular}{|c|c|c|c|}
\hline \multicolumn{4}{|c|}{$\begin{array}{l}\text { SISTEMA DE INFORMACÕES DA PREVISÃO OPERACIONAL - SIPO } \\
\text { NOYOS PROJETOS }\end{array}$} \\
\hline \multicolumn{2}{|l|}{ Data de Referência: 03/07/2012 } & \multicolumn{2}{|c|}{ Valores Apresentados em: $\mathrm{ms} / \mathrm{dia}$} \\
\hline Plataforma & Poço & Data de Início & Potencial Previsto \\
\hline FPSO P-57 & JUB-4HP & $07 / 08 / 12$ & 965 \\
\hline FPSO CIDADE VITÓRIA & GLF-34 & $11 / 08 / 12$ & 1.113 \\
\hline FPSO ANCHIETA & 7-BAZ-2-ESS & $31 / 08 / 12$ & 3.500 \\
\hline FPSO CAPIXABA & 7-BFR-6-ESS & $01 / 09 / 12$ & 1.065 \\
\hline FPSO ANCHIETA & 7-BAZZ-3-ESS & $08 / 09 / 12$ & 3.500 \\
\hline FPSO ANCHIETA & 7-BAZ-6-ESS & $17 / 09 / 12$ & 2.200 \\
\hline FPSO P-57 & JUB-2HPA & $19 / 09 / 12$ & 998 \\
\hline $\mathrm{P}-18$ & MRL-215 & $14 / 09 / 12$ & 600 \\
\hline$P-56$ & MLS-187 B9P5 & $15 / 08 / 12$ & 2.067 \\
\hline FPSO CIDADE DE SANTOS & TBU-GH1 & $04 / 08 / 12$ & 76 \\
\hline FPSO CIDADE DE SANTOS & $\mathrm{TBU}-2 \mathrm{H}$ & $04 / 08 / 12$ & 76 \\
\hline
\end{tabular}

Fonte: O autor, (2012). 
Dados Determinísticos de Qualidade:

- Eventos de qualidade: eventos previstos para os dois meses seguintes, que possam alterar a qualidade do óleo estocado nos tanques da plataforma. A qualidade prevista neste período será utilizada na projeção de estoque e qualidade de óleo para os dois meses seguintes. Estes eventos deverão ser descritos para que ações possam ser tomadas de modo a garantir a qualidade do óleo. Exemplos de eventos são manutenções programadas nas plantas de tratamento do óleo. Abaixo segue exemplo, através da Tabela 13, dos dados determinísticos de qualidade que deverão ser coletados.

Tabela 13 - Exemplo de Dados Determinísticos de Qualidade

\begin{tabular}{|c|c|c|c|c|}
\hline Evento & Data Início & Data Fim & BSW (\%) & Descriçẫo \\
\hline Manutençẫo Programada & $25 / 08 / 11$ & $30 / 08 / 11$ & $>5$ & Inspeçẫo do Tratador de Óleo - A \\
\hline
\end{tabular}

Fonte: O autor, (2012).

\section{Dados Determinísticos de Tancagem:}

- Eventos de tancagem: dados de capacidade de projeto da plataforma e sua indisponibilidade permanente (conceitos descritos no item 3.1. Diagnóstico da Situação Atual). Através destes dados se calcula a sua capacidade operacional máxima. Os demais dados são eventos previstos para os dois meses seguintes que possam alterar a capacidade operacional de armazenagem de forma variável ao longo tempo, sendo informadas as datas de início e fim de cada evento e sua variação. Estas variações serão utilizadas para calcular a capacidade operacional da plataforma durante o período previsto. Por outro lado, os eventos deverão ser descritos e acompanhados para que ações possam ser tomadas de modo a garantir o cumprimento do seu prazo, a fim de evitar atrasos. Exemplos de eventos são inspeções e manutenções programadas nos tanques da plataforma. Abaixo segue exemplo, através da Tabela 14, dos dados determinísticos de tancagem que deverão ser coletados. 
Tabela 14 - Exemplo de Dados Determinísticos de Tancagem

\begin{tabular}{|c|c|c|c|c|}
\hline Capacidade de Projeto & 286.000 \\
\cline { 1 - 2 } Indisponibilidade Permanente & 50.000 \\
\begin{tabular}{|c|c|cc|c|}
\hline \multicolumn{5}{|c|}{ Indisponibilidade Variável } \\
\hline Evento & Data Início & Data Fim & $\begin{array}{c}\text { Variaçã̃o } \\
\left(\mathrm{m}^{3}\right)\end{array}$ & Descriçẫo \\
\hline Inspeçẫo de Tanque & $05 / 07 / 11$ & $12 / 07 / 11$ & -25.000 & Inspeçẫo do Tanque 4-C \\
\hline Manutençẫo Programada & $19 / 07 / 11$ & $13 / 08 / 11$ & -25.000 & Manutençẫo do Tanque 4-C \\
\hline
\end{tabular}
\end{tabular}

Fonte: $\mathrm{O}$ autor, (2012).

\section{$\underline{\text { Dados Determinísticos de Lastro: }}$}

- Eventos de lastro: dados de lastro operacional e eventos previstos para os dois meses seguintes que possam alterá-lo de forma variável ao longo tempo, em função da condição de mar, da manutenção ou inspeção de tanques, situações estas em que se altera a configuração dos esforços estruturais distribuídos pela plataforma. Deverão ser informadas as datas de início e fim de cada evento e sua variação. Estas variações serão utilizadas para calcular o lastro operacional da plataforma durante o período previsto. Por outro lado, os eventos deverão ser descritos e acompanhados para que ações possam ser tomadas de modo a garantir o cumprimento do seu prazo, a fim de evitar atrasos. Abaixo segue exemplo, através da Tabela 15, dos dados determinísticos de lastro que deverão ser coletados.

Tabela 15 - Exemplo de Dados Determinísticos de Lastro \begin{tabular}{|l|l|}
\hline Lastro Operacional & 100.000 \\
\hline
\end{tabular}

\begin{tabular}{|c|c|c|c|c|}
\hline \multicolumn{5}{|c|}{ Indisponibilidade Variável } \\
\hline Evento & Data Início & Data Fim & $\begin{array}{c}\text { Variaçẫo } \\
\left(\mathrm{m}^{3}\right)\end{array}$ & Descriçẫo \\
\hline Inspeçẫo de Tanque & $05 / 07 / 11$ & $12 / 07 / 11$ & 30.000 & Inspeçẫo do Tanque 4-C \\
\hline Manutençẫo Programada & $19 / 07 / 11$ & $13 / 08 / 11$ & 30.000 & Manutençẫo do Tanque 4-C \\
\hline
\end{tabular}

Fonte: O autor, (2012).

\section{Dados Determinísticos de Offloading:}

- Eventos de offloading: estes eventos se dividem em:

- dados de capacidade de bombeio de óleo da plataforma para o navio aliviador (dados de projeto e operacional) e eventos previstos para os dois 
meses seguintes que possam alterá-lo de forma variável ao longo tempo, em função de manutenção programada, por exemplo. Deverão ser informadas as datas de início e fim de cada evento e sua variação. Estas variações serão utilizadas para calcular a capacidade operacional de vazão da bomba durante o período previsto. Por outro lado, os eventos deverão ser descritos e acompanhados para que ações possam ser tomadas de modo a garantir o cumprimento do seu prazo, a fim de evitar atrasos. Abaixo segue exemplo, através da Tabela 16, dos dados determinísticos de capacidade de bombeio que deverão ser coletados.

Tabela 16 - Exemplo de Dados Determinísticos de Offloading - Capacidade de Bombeio \begin{tabular}{|l|l|l|}
\hline Capacidade de Bombeio de Projeto $\left(\mathrm{m}^{3} / \mathrm{h}\right)$ & 12.000 \\
\hline
\end{tabular} \begin{tabular}{|l|l|l}
\hline Capacidade de Bombeio Operacional $\left(\mathrm{m}^{3} / \mathrm{h}\right)$ & 12.000 \\
\hline
\end{tabular}

\begin{tabular}{|c|c|c|c|c|}
\hline Evento & Data Início & Data Fim & Variaçẫo $\left(\mathrm{m}^{3} / \mathrm{h}\right)$ & Descriçẫo \\
\hline Manutençẵo Nẫo Programada & $05 / 07 / 11$ & $06 / 07 / 11$ & -4.000 & Manutençẫo da bomba A \\
\hline
\end{tabular}

Fonte: O autor, (2012).

- eventos previstos para os dois meses seguintes que possam impedir a realização da operação de offloading, seja por indisponibilidade dos equipamentos de offloading, como, por exemplo, uma bomba ou um mangote, ou devido ao fato de haver uma operação que impeça a aproximação de outro navio simultaneamente, como numa operação de interligação de um poço à plataforma ou desconexão de um poço, quando há barcos de apoio atuando nas imediações da plataforma, pondo em risco as vidas das pessoas envolvidas. Deverão ser informadas as datas de início e fim de cada evento para que não seja programada nenhuma operação de offloading durante este período. Por outro lado, os eventos deverão ser descritos e acompanhados para que ações possam ser tomadas de modo a garantir o cumprimento do seu prazo, a fim de evitar atrasos. Abaixo segue exemplo, através da Tabela 17, dos dados determinísticos referentes às restrições das operações de offloading que deverão ser coletados.

Tabela 17 - Exemplo de Dados Determinísticos de Offloading - Restrições das Operações

\begin{tabular}{|c|c|c|c|}
\hline Eventos que Impedem Offioading & Data Início & Data Fim & Descriçẫo \\
\hline Interligaçẫo de Poço & $05 / 08 / 11$ & $08 / 08 / 11$ & Entrada do poço XYZ \\
\hline
\end{tabular}

Fonte: O autor, (2012). 
- offloadings programados para os dois meses seguintes, em função de compromissos de exportação, ou por necessidades especiais das refinarias e/ou necessidades especiais das plataformas, visando operações de offloading de óleo fora de especificação ou água livre, caso ocorram problemas operacionais. Em ambas as situações, estas programações devem ser consideradas como prioridade para a projeção de estoque e qualidade para os próximos dois meses. Deverão ser informadas as datas de início e fim de cada evento ao longo do período previsto e os volumes de óleo, em função da sua qualidade (teor de BSW), ou água (em situações contingenciais), a serem retirados. Abaixo segue exemplo, através da Tabela 18, dos dados determinísticos referentes aos offloadings programados.

Tabela 18 - Exemplo de Dados Determinísticos de Offloading - Offloadings Programados

\begin{tabular}{|c|c|c|c|c|c|}
\hline Offloadings Programados & Data Início & Data Fim & Lote ( $\mathrm{m} 3)$ & Fluido & BSW $(\%)$ \\
\hline Exportaçăo & $10 / 08 / 11$ & $12 / 08 / 11$ & 160.000 & Óleo & $<0,5$ \\
\hline
\end{tabular}

Fonte: O autor, (2012).

Para a coleta dos eventos determinísticos foi criado um novo fluxo de informações no qual as gerências de Planejamento, Desenvolvimento e Controle da Produção (PDCP) dos Ativos de Produção de cada Unidade Operacional preencherão, mensalmente, uma planilha com eventos previstos para os dois meses seguintes, que possam alterar os parâmetros de qualidade, tancagem, lastro e de offloading. Está sendo planejada a utilização futura do sistema SIPO para o fluxo de informações de todos os dados determinísticos.

Através da Figura 9 é apresentado o fluxograma das atividades do processo Coletar Dados Determinísticos.

Segue abaixo a descrição da sigla utilizada no fluxo de atividades deste processo e que ainda não havia sido explicada neste trabalho:

CPGP: gerência de Controle da Produção e Gestão de Produtos das unidades operacionais. Cada unidade operacional possui uma gerência deste tipo; 


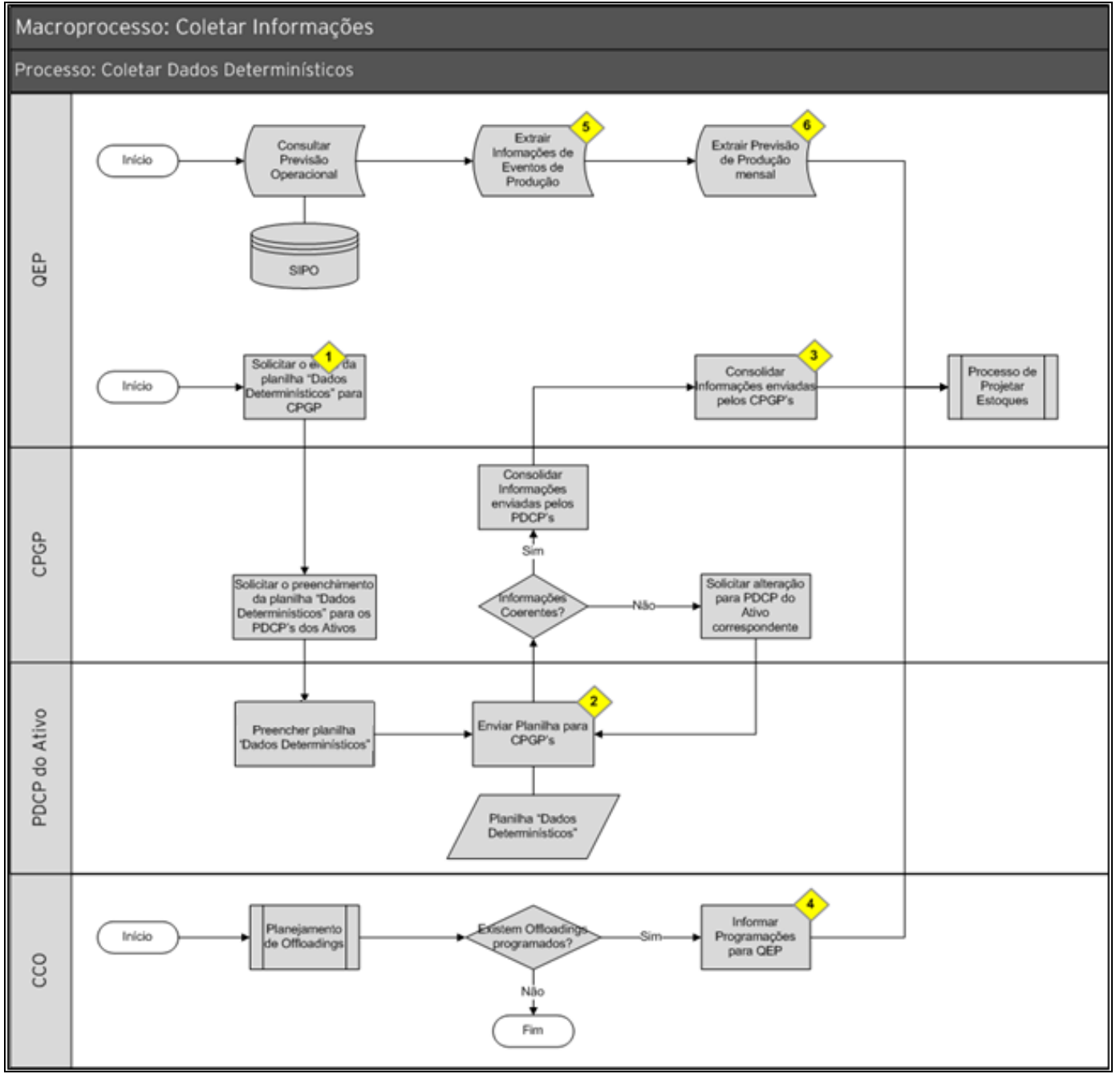

Figura 9 - Fluxograma do processo "Coletar Dados Determinísticos"

Fonte: O autor, (2012).

A gerência de Qualidade e Estoque de Produtos (QEP) solicita, mensalmente, o envio da planilha "Dados Determinísticos.xls" (contendo eventos previstos que alteram a qualidade do óleo produzido, a capacidade operacional de tancagem, o lastro e a vazão das bombas de transferência, além das restrições de escoamento e os offloadings já programados para os dois meses seguintes) para as gerências de Controle da Produção e Gestão de Produtos (CPGP) de cada unidade operacional.

A gerência de Planejamento, Desenvolvimento e Controle da Produção (PDCP) de cada ativo de produção de cada unidade operacional (UO) preenche a planilha "Dados Determinísticos.xls" relativa a cada plataforma do seu ativo e envia à respectiva gerência de Controle da Produção e Gestão de Produtos (CPGP) da UO. 
Através da Tabela 19 é apresentada a planilha "Dados Determinísticos.xls" preenchida, como exemplo, com dados fictícios.

Tabela 19 - Planilha Dados Determinísticos (dados fictícios)

\begin{tabular}{|c|c|c|c|c|c|c|}
\hline & Informaçöes de Tancagem & Informaccues de Bombeio & Informacueses de Lastio & & & \\
\hline Capacidade de Projeto & $206.000 \mathrm{~m}^{9}$ & $13.500 \mathrm{~m} / \mathrm{h}$ & & & & \\
\hline Indisponibilidade Permanente & $50.000 \mathrm{~m}^{2}$ & & & & & \\
\hline Operacional & $236.000 \mathrm{~m}^{2}$ & $6.000 \mathrm{~m}^{2} / \mathrm{h}$ & $100.000 \mathrm{~m}^{2}$ & & & \\
\hline Evento & Tppo de Evento & Data licio Prenisto & Data Fim Prenisto & BSW\% & Vaniaçäo & Descriçat \\
\hline Qualidade & Inspeçẫo de Equipamento & 13/08/12 & $20,08 / 12$ & Entre $1 \%$ e $5 \%$ & & Inspecção do TO-A \\
\hline Qualidade & Manutençẫo Programada & $25 / 08 / 12$ & $30 / 08 / 12$ & $>5 \%$ & & Manutenção do TO.B \\
\hline Tancagem & Inspeção de Tanque & $05 / 08 / 12$ & $12008 / 12$ & & $.30 .000 \mathrm{~m}^{2}$ & Inspeeção do Tanque 4.C \\
\hline Tancagem & Manutençâo Programada & $14 / 08 / 12$ & 14/09/12 & & $.30 .000 \mathrm{~m}^{2}$ & Manutenção do Tanque 4.C \\
\hline Restricao Offloading & Entrada de Pocco & $05 / 08 / 12$ & $08: 08 / 12$ & & & Entrada do poco XYZ \\
\hline Vazao Ofloading & Manutenção Não programada Planejajuel & $11 / 08 / 12$ & $1208 / 12$ & & $.500 \mathrm{~m}^{3} \mathrm{~h}$ & Manutenção da bomba A \\
\hline Lastio & Manutenção Programada & $1408 / 12$ & 14/09/12 & & $20.000 \mathrm{~m}^{3}$ & Manutencão do Tanque 4-C \\
\hline
\end{tabular}

Fonte: O autor, (2012).

A gerência de gerência de Qualidade e Estoque de Produtos (QEP) consolida as informações fornecidas pelas áreas Controle da Produção e Gestão de Produtos (CPGP) de cada UO;

O CCO (Centro de Controle Operacional) consolida e informa à gerência de Qualidade e Estoque de Produtos (QEP) as programações que não devem ser alteradas, devido a necessidades especiais, seja do Abastecimento ou do E\&P;

A gerência de Qualidade e Estoque de Produtos (QEP) deve extrair do SIPO as informações de eventos que influenciarão o volume produzido pela plataforma. Estes eventos podem ser paradas programadas, entrada ou saída de poços.

6 A gerência de Qualidade e Estoque de Produtos (QEP) deve extrair do SIPO a previsão operacional (estimativa trimestral), com informações da média mensal de produção diária.

\subsection{2}

\section{Projetar Estoques}

Este macroprocesso consiste em projetar os estoques dos fluidos armazenados nas plataformas e a sua qualidade e, por consequência, os estoques de óleo disponíveis para elaborar a programação de navios tanto para as retiradas 
de petróleo com destino para as refinarias nacionais quanto para exportação, ambos os processos realizados pela área de Logística, do segmento Abastecimento da empresa.

Nesta etapa, o grande desafio é compreender e modelar o comportamento dos estoques e a sua qualidade ao longo do período previsto, seja utilizando dados determinísticos ou dados históricos coletados no macroprocesso anterior.

A projeção dos estoques deverá ocorrer mais de uma vez a cada ciclo do planejamento tático, de forma que sejam comparados os diferentes cenários e que seja selecionado o cenário de projeção que melhor atenda aos objetivos de negócio da empresa, às restrições operacionais e, se possível, à otimização dos estoques das plataformas no período projetado.

É importante destacar que, durante a análise de cenários, questionamentos devem ser feitos a respeito das possíveis ineficiências dos processos e de situações indesejadas, devendo ser criados planos de ação e situações de contorno para evitá-las. Nesta etapa do processo, a análise de riscos pode ser utilizada.

Para projetar os estoques está sendo desenvolvida uma ferramenta de suporte, que recebeu o nome de SIGEP (Sistema de Gestão de Estoque de Petróleo), através do qual será possível representar e simular o comportamento dos estoques e a qualidade dos fluidos armazenados.

Uma vez que a quantidade de dados de entrada de informações na ferramenta é elevada, foi necessário criar uma interface de entrada de dados a fim de organizar as informações que o usuário precisa preencher.

Devido ao elevado volume de entrada de dados, possíveis erros de preenchimento manual do usuário são passíveis de ocorrer. Tais erros podem comprometer a qualidade da projeção, podendo gerar resultados incompatíveis com a realidade operacional. Para evitar situações deste tipo, serão criadas, no futuro, interfaces com os sistemas WEBEP e SIPO, fontes dos dados, de modo a garantir a sua integridade.

Através da Figura 10 é apresentado um esquemático da arquitetura básica do sistema, onde são representados os fornecedores dos dados e as variáveis de entrada (inputs) do sistema. Tanto os fornecedores dos dados de entrada quanto os próprios dados de entrada foram detalhados nos fluxogramas dos processos que compõem o macroprocesso “Coletar Informações”, vistos nos tópicos anteriores. 
Todos os dados coletados serão registrados, num primeiro momento, manualmente, através de uma interface de dados construída na plataforma Access da Microsoft, até que sejam construídas as interfaces necessárias com os demais sistemas para sua automatização. A partir desta entrada de dados, será possível selecionar alguns parâmetros, que serão detalhados adiante, para que sejam efetuadas as projeções dos estoques. No momento em que todas as informações necessárias forem preenchidas, poderá ser dado o comando para a projeção, quando as informações armazenadas no banco de dados Access serão migradas para um ambiente gráfico e integrado de simulação, em desenvolvimento na Petrobras, de onde será possível simular as projeções de estoques baseando-se nos dados de entrada e nas parametrizações efetuadas. As saídas do simulador serão arquivos e gráficos em formato Excel, contendo dados previstos de produção, estoques, qualidade, variações da capacidade de tancagem e do lastro, retiradas de petróleo e demais dados, ao longo do período desejado. Após a realização das operações, serão coletados e calculados os indicadores de desempenho do processo de gestão de estoques.

Devem ser utilizados modelos matemáticos baseados nos dados históricos de produção, qualidade e estoque para serem projetados os volumes produzidos, de acordo com a sua qualidade e os estoques dos fluidos armazenados.

Em paralelo, os dados determinísticos de previsão de produção do SIPO (que podem ser utilizados, como alternativa, para a previsão dos volumes produzidos, caso, por exemplo, os dados históricos possuam uma tendência de queda ou crescimento que não correspondam à realidade), os eventos de parada programada e entrada e saída de poços, e os eventos previstos de qualidade, tancagem, lastro e offloading serão registrados no sistema da mesma maneira, através da interface em Access. Futuramente serão desenvolvidas interfaces com os sistemas WEBEP e SIPO para que todas as informações sejam migradas automaticamente para o sistema SIGEP.

Uma vez que todas as informações necessárias estejam armazenadas no sistema, será preciso selecionar que previsão de produção utilizar (baseada no histórico ou no SIPO), informar a capacidade do navio aliviador e dar o comando de simulação. 


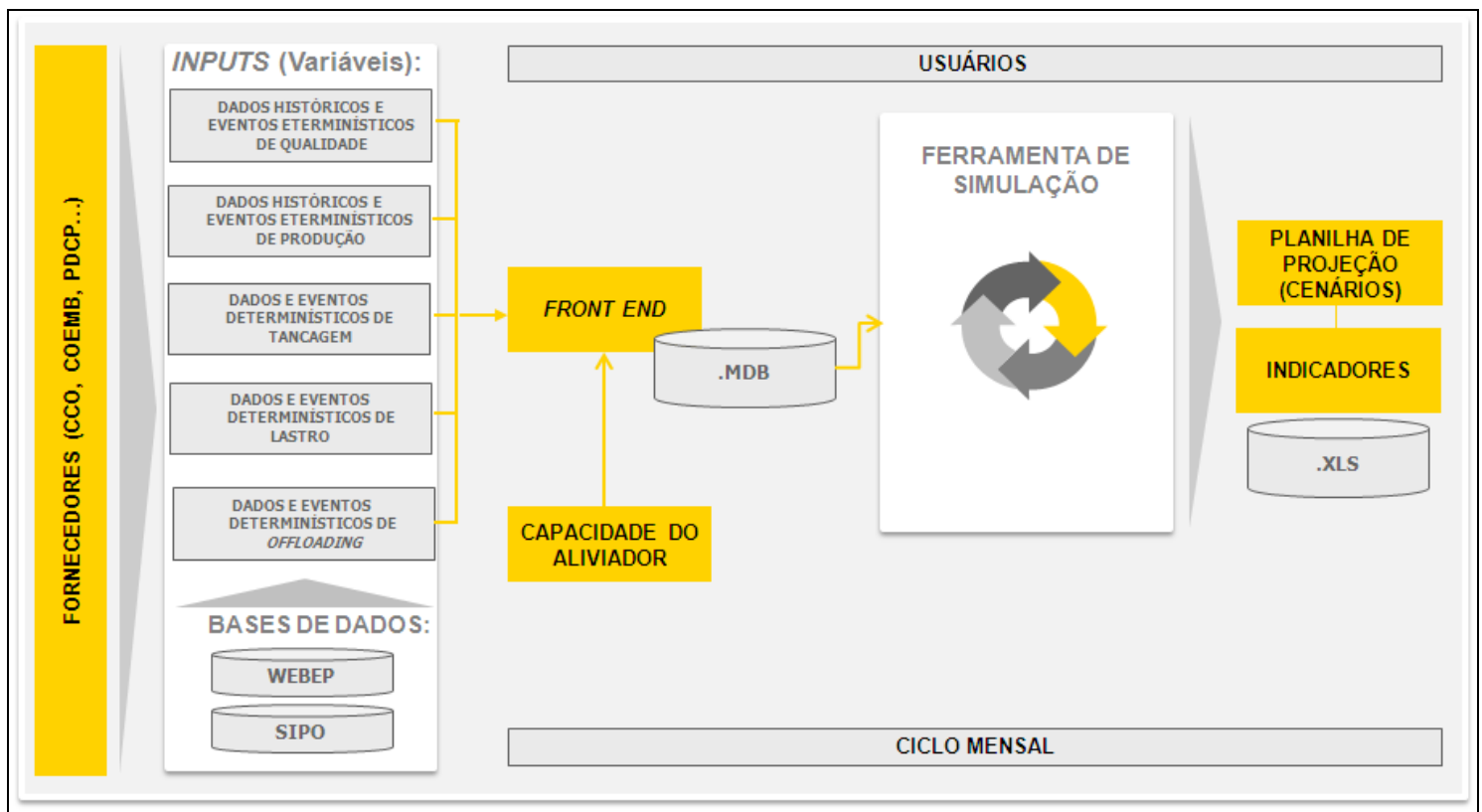

Figura 10 - Esquemático da Arquitetura Básica do Sistema de Gestão de Estoque de Petróleo Fonte: O autor, (2012).

A navegação na interface do sistema se dará por meio de menus e telas para a entrada de dados.

A tela inicial do sistema, apresentada na Figura 11, possui um botão de controle para cada interface de dados que, ao serem clicados, abrem uma nova janela de edição.

Nas telas de edição, mensagens em caixas de texto guiam o usuário em seu preenchimento.

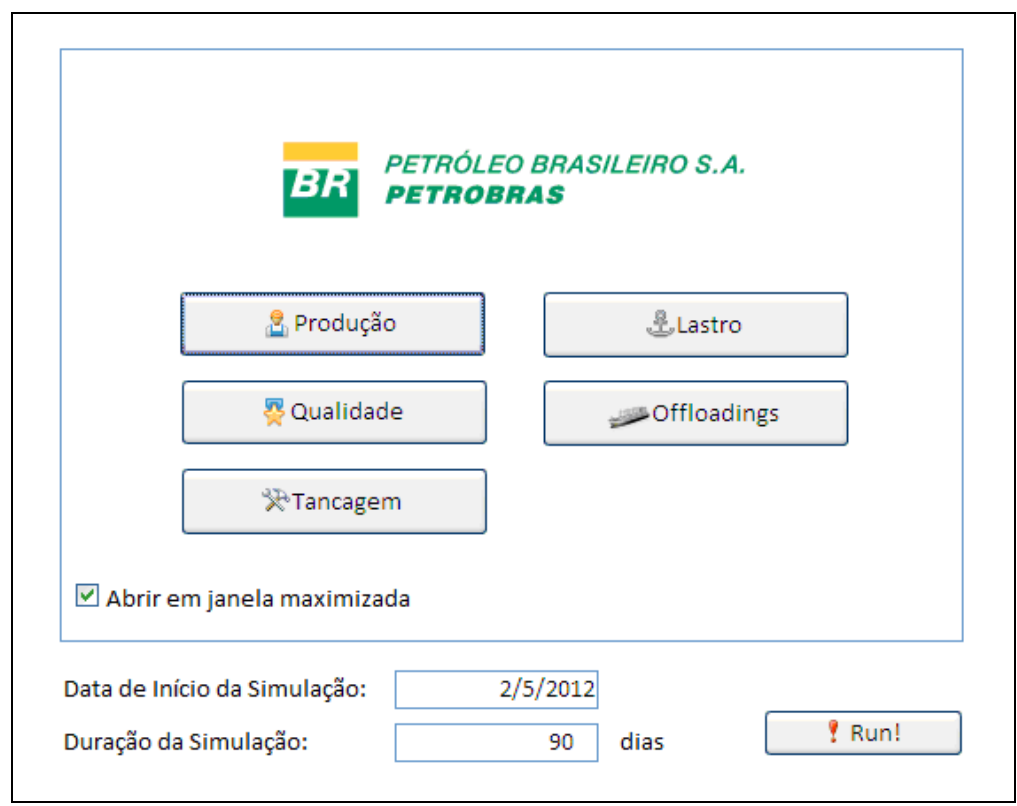

Figura 11 - Tela Inicial do Sistema de Gestão de Estoque de Petróleo (SIGEP) Fonte: O autor, (2012). 
É apresentado, através da Figura 12, o detalhamento do macroprocesso "Projetar Estoques", indicando os processos que o compõem. Em seguida, é descrito o detalhamento de cada um destes processos e o fluxograma das suas atividades.

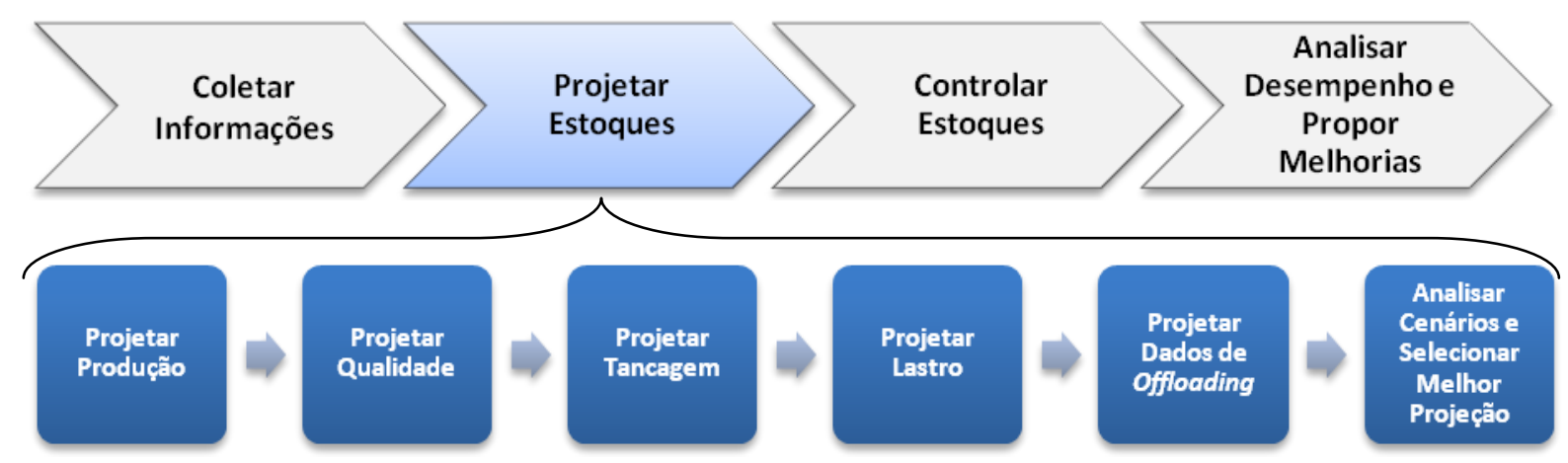

Figura 12 - Detalhamento do Macroprocesso "Projetar Estoques" Fonte: O autor, (2012).

\subsubsection{1}

Projetar Produção

É apresentado, através da Figura 13, o fluxograma das atividades do processo Projetar Produção.

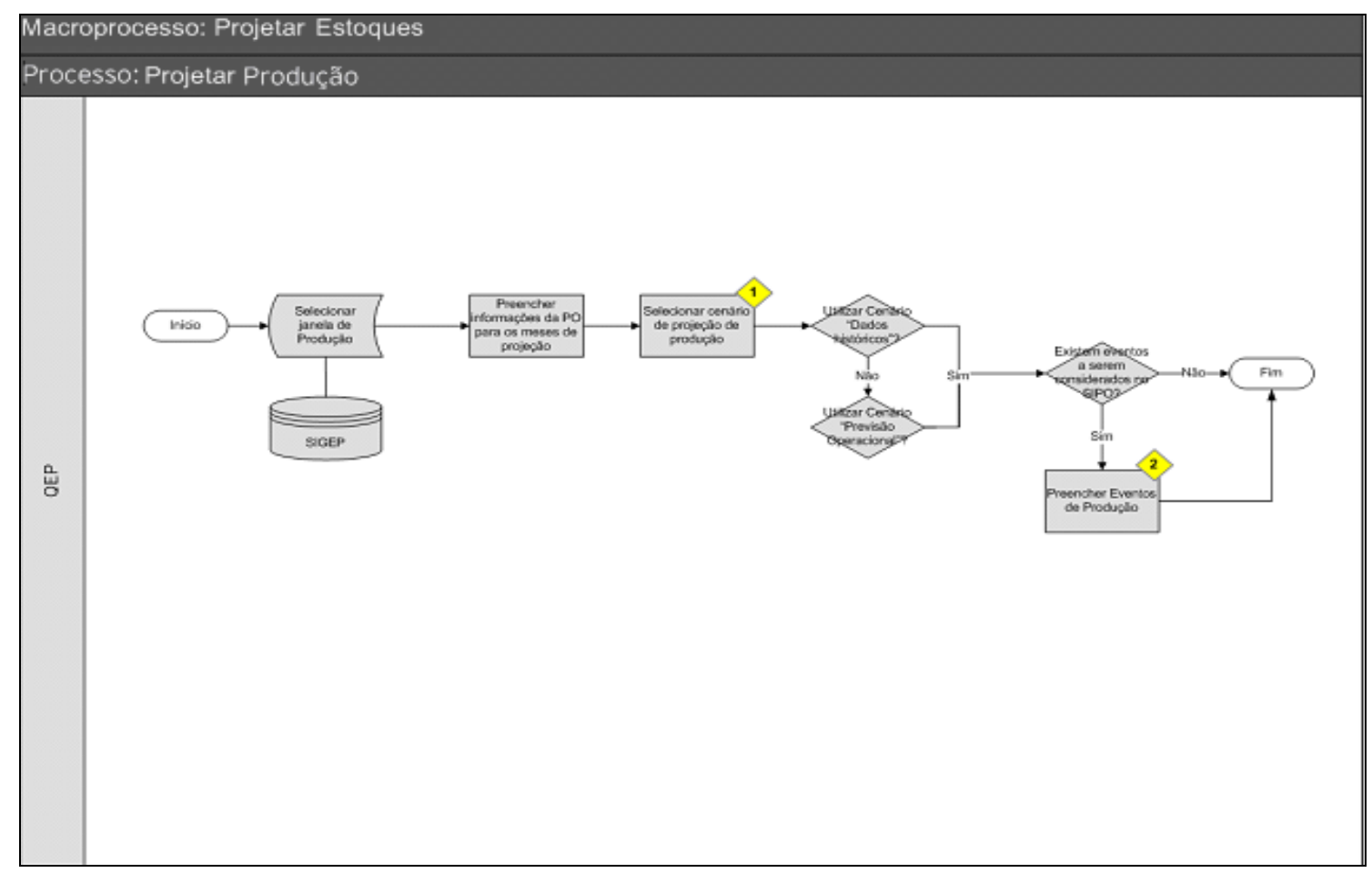

Figura 13 - Fluxograma do processo Projetar Produção

Fonte: $\mathrm{O}$ autor, (2012). 
A gerência de Qualidade e Estoque de Produtos (QEP) deve selecionar um dos dois cenários de projeção de produção disponíveis:

- "Utilizar Média Histórica": habilita como entrada de dados no simulador a média histórica da produção para projetar a produção diária para o período previsto ou

- "Utilizar Previsão Operacional": habilita como entrada de dados no simulador a média mensal (em m³/dia) prevista na Previsão Operacional (PO), extraída do sistema SIPO, para projetar a produção diária para o período previsto.

Neste momento devem-se analisar as informações para se tomar a melhor decisão sobre qual alternativa utilizar para a projeção da produção. Se há uma tendência de crescimento ou queda da produção, baseando-se apenas nos dados históricos, mas que não correspondam à realidade operacional, talvez seja mais adequado utilizar a previsão operacional. Por outro lado, como a previsão operacional é estimada pela própria unidade operacional, e por haver um pouco de subjetividade neste processo, pode ocorrer certo otimismo ou pessimismo por parte da equipe envolvida, dependendo das expectativas de cada um. De forma a minimizar este efeito indesejado, deve-se também utilizar o índice recente de assertividade da previsão de produção (realizado / previsto) para auxiliar na tomada de decisão.

Após a explicação do fluxograma das atividades, será detalhado como o simulador calcula a média histórica da produção.

Após selecionar o cenário de projeção da produção, devem ser preenchidos (na tabela de eventos de produção) os eventos determinísticos, oriundos do Sistema de Previsão Operacional (SIPO), que impactam na redução ou aumento da produção.

Através da Figura 14 é apresentada a tela de entrada de dados de produção do sistema de gestão de estoque de petróleo (SIGEP). Nesta tabela os campos "Evento", "Data Início", "Data Fim” e "Variação Evento" são entradas de dados. Já as colunas da direita são calculadas de acordo com as definições de cenários, considerando as variações dos eventos nas datas indicadas. 


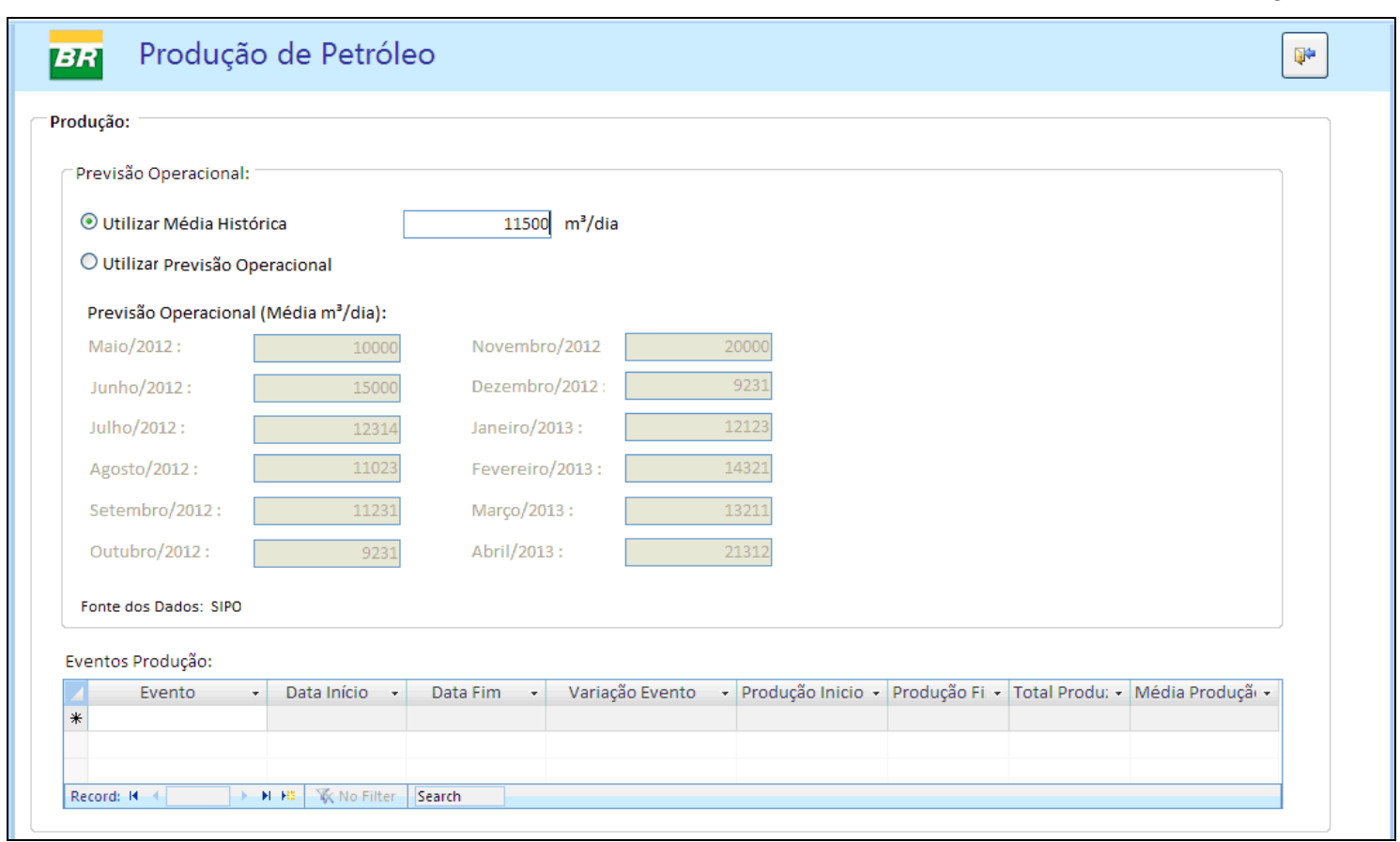

Figura 14 - Tela de Entrada de Dados de Produção do Sistema de Gestão de Estoque de Petróleo Fonte: O autor, (2012).

Através da Tabela 20 é apresentado um exemplo de como o sistema calcula a projeção dados os eventos determinísticos que influenciam a produção. Apesar da produção variar ao longo do mês em função das paradas programadas de produção ou da entrada e saída de poços, a média mensal da produção deve continuar sendo a mesma que a prevista na previsão operacional ou a média histórica calculada pelo próprio simulador, dependendo da decisão sobre o melhor cenário a ser utilizado. 
Tabela 20 - Exemplo (fictício) de Projeção de Estoques considerando Eventos Determinísticos de Produção

\begin{tabular}{|c|c|c|c|}
\hline \multicolumn{2}{|c|}{ Previsão Operacional } & & \\
\hline & Média Mensal (m3/dia) & & \\
\hline Maio/2012 & 10.000 & & \\
\hline Evento & Data Início & Data Fim & Variação Evento \\
\hline $\begin{array}{c}\text { Parada Programada } \\
\text { Parcial }\end{array}$ & $10 /$ mai & $20 /$ mai & -1.000 \\
\hline
\end{tabular}

\begin{tabular}{|c|c|c|c|}
\hline Produção Início & Produção Fim & Total Produção Evento & Média Produção \\
\hline 9.000 & 9.000 & 99.000 & 10.000 \\
\hline
\end{tabular}

Projeção Maio/2012

\begin{tabular}{|c|c|c|c|}
\hline \multicolumn{4}{|c|}{ Projeção Maio/2012 } \\
\hline $1 / 5 / 2012$ & 10.550 & 16/mai & 9.000 \\
\hline $2 / 5 / 2012$ & 10.550 & 17/mai & 9.000 \\
\hline $3 / 5 / 2012$ & 10.550 & 18/mai & 9.000 \\
\hline $4 / 5 / 2012$ & 10.550 & 19/mai & 9.000 \\
\hline $5 / 5 / 2012$ & 10.550 & $20 / \mathrm{mai}$ & 9.000 \\
\hline $6 / 5 / 2012$ & 10.550 & $21 / \mathrm{mai}$ & 10.550 \\
\hline $7 / 5 / 2012$ & 10.550 & $22 /$ mai & 10.550 \\
\hline $8 / 5 / 2012$ & 10.550 & 23/mai & 10.550 \\
\hline $9 / 5 / 2012$ & 10.550 & $24 / \mathrm{mai}$ & 10.550 \\
\hline $10 / 5 / 2012$ & 9.000 & $25 /$ mai & 10.550 \\
\hline $11 / 5 / 2012$ & 9.000 & $26 /$ mai & 10.550 \\
\hline $12 / 5 / 2012$ & 9.000 & $27 /$ mai & 10.550 \\
\hline $13 / 5 / 2012$ & 9.000 & $28 /$ mai & 10.550 \\
\hline $14 / 5 / 2012$ & 9.000 & 29/mai & 10.550 \\
\hline $15 / 5 / 2012$ & 9.000 & $30 / \mathrm{mai}$ & 10.550 \\
\hline \multirow{2}{*}{$10 / 0 / 20 / 2$} & & $31 / \mathrm{mai}$ & 10.550 \\
\hline & & Média & 10.000 \\
\hline
\end{tabular}

Fonte: O autor, (2012).

Considerando o exemplo acima:

Produção Total do Mês = média da produção diária da Previsão Operacional $\mathrm{x}$ número de dias do mês

Produção de Maio/2012 $=10.000$ x $31=310.000$

Produção Total durante a parada programada $=9.000 \times 11=99.000$

Produção Total (31 dias) - Produção durante Evento $(11$ dias $)=310.000-99.000$ $=211.000$ (= produção durante 20 dias sem parada)

Produção média dos demais dias $($ sem parada $)=211.000 / 20=10.550$

Para o simulador calcular a média histórica da produção, será utilizado como dado de entrada o histórico da produção bruta (óleo + água emulsionada) coletado no macroprocesso anterior. A previsão se dará com base nos modelos 
constante ou linear de previsão de demanda, sendo utilizados os métodos de amortecimento exponencial simples ou duplo, apresentados na revisão bibliográfica (capítulo 2), a depender do estágio do ciclo de vida da produção do reservatório.

Através da Tabela 21 é apresentado um exemplo de dados históricos (fictícios) da produção bruta de uma determinada plataforma, onde não se observa tendência de crescimento ou decrescimento da produção.

Tabela 21 - Dados Históricos (fictícios) da Produção Bruta - Modelo Constante

\begin{tabular}{|c|c|c|c|}
\hline Mês & $\begin{array}{c}\text { Produção } \\
\text { Bruta (m3/dia) }\end{array}$ & Mês & $\begin{array}{c}\text { Produção } \\
\text { Bruta (m3/dia) }\end{array}$ \\
\hline jan-10 & 6.172 & jun-11 & 5.185 \\
\hline fev-10 & 4.893 & jul-11 & 5.602 \\
\hline mar-10 & 6.067 & ago-11 & 7.310 \\
\hline abr-10 & 6.371 & set-11 & 4.895 \\
\hline mai-10 & 6.824 & out-11 & 4.665 \\
\hline jun-10 & 6.344 & nov-11 & 6.108 \\
\hline jul-10 & 6.883 & dez-11 & 5.483 \\
\hline ago-10 & 6.556 & jan-12 & 6.967 \\
\hline set-10 & 5.653 & fev-12 & 7.011 \\
\hline out-10 & 5.035 & mar-12 & 5.883 \\
\hline nov-10 & 5.395 & abr-12 & 5.991 \\
\hline dez-10 & 4.682 & mai-12 & 4.612 \\
\hline jan-11 & 6.670 & jun-12 & 7.173 \\
\hline fev-11 & 5.892 & jul-12 & 4.566 \\
\hline mar-11 & 5.071 & ago-12 & 5.991 \\
\hline abr-11 & 5.591 & set-12 & 5.112 \\
\hline mai-11 & 5.436 & & \\
\cline { 1 - 3 } & \multicolumn{3}{|l}{}
\end{tabular}

Fonte: O autor, (2012).

A seguir é apresentada a simulação das previsões de produção para os dois meses seguintes (out-12 e nov-12), de acordo com o modelo constante, utilizandose o método de amortecimento exponencial simples, e o erro médio quadrático correspondente.

- Método de Amortecimento Exponencial Simples: utilizou-se a média ponderada da produção (fictícia) dos 10 meses anteriores à data de início da previsão para calcular a produção dos dois meses seguintes. A amostra (fictícia) coletada se refere ao período de jan-10 até set-12. A constante de amortecimento $(\alpha)$ foi escolhida através da ferramenta solver, do Microsoft Excel, de modo a minimizar o erro médio quadrático (EMQ). A amostra (fictícia) utilizada para prever a produção pelo amortecimento exponencial foi de dez-11 até set-12 e a amostra (fictícia) utilizada para calcular o erro da previsão foi de nov-10 até set-12, 
conforme apresentado através da Tabela 22, cujo erro médio quadrático foi de $2,64 \%$.

Erro\% $=($ produção - previsão $) /$ produção x 100

Erro Quadrático $=(\text { Erro } \%)^{2}$

Erro Médio Quadrático $=($ soma dos Erros Quadráticos $) / n^{0}$ de previsões (Eq. 14)

Tabela 22 - Simulação da Previsão de Produção e do Erro Médio Quadrático (EMQ) Amortecimento Exponencial Simples

\begin{tabular}{|c|c|c|c|c|c|c|c|c|c|}
\hline Mês & $\begin{array}{c}\text { Produção } \\
\text { Bruta (m3/dia) }\end{array}$ & Previsão & Erro\% & $\begin{array}{c}\text { Erro } \\
\text { Quadrático }\end{array}$ & Mês & $\begin{array}{c}\text { Produção } \\
\text { Bruta (m3/dia) }\end{array}$ & Previsão & Erro\% & $\begin{array}{c}\text { Erro } \\
\text { Quadrático }\end{array}$ \\
\hline jan-10 & 6.172 & & & & jul-11 & 5.602 & 5.743 & $-2,5 \%$ & $0,1 \%$ \\
\hline fev-10 & 4.893 & & & & ago-11 & 7.310 & 5.729 & $21,6 \%$ & $4,7 \%$ \\
\hline mar-10 & 6.067 & & & & set-11 & 4.895 & 5.882 & $-20,2 \%$ & $4,1 \%$ \\
\hline abr-10 & 6.371 & & & & out-11 & 4.665 & 5.787 & $-24,0 \%$ & $5,8 \%$ \\
\hline mai-10 & 6.824 & & & & nov-11 & 6.108 & 5.678 & $7,0 \%$ & $0,5 \%$ \\
\hline jun-10 & 6.344 & & & & dez-11 & 5.483 & 5.720 & $-4,3 \%$ & $0,2 \%$ \\
\hline jul-10 & 6.883 & & & & jan-12 & 6.967 & 5.697 & $18,2 \%$ & $3,3 \%$ \\
\hline ago-10 & 6.556 & & & & fev-12 & 7.011 & 5.820 & $17,0 \%$ & $2,9 \%$ \\
\hline set-10 & 5.653 & & & & mar-12 & 5.883 & 5.935 & $-0,9 \%$ & $0,0 \%$ \\
\hline out-10 & 5.035 & & & & abr-12 & 5.991 & 5.930 & $1,0 \%$ & $0,0 \%$ \\
\hline nov-10 & 5.395 & 6.080 & $-12,7 \%$ & $1,6 \%$ & mai-12 & 4.612 & 5.936 & $-28,7 \%$ & $8,2 \%$ \\
\hline dez-10 & 4.682 & 6.014 & $-28,4 \%$ & $8,1 \%$ & jun-12 & 7.173 & 5.808 & $19,0 \%$ & $3,6 \%$ \\
\hline jan-11 & 6.670 & 5.885 & $11,8 \%$ & $1,4 \%$ & jul-12 & 4.566 & 5.940 & $-30,1 \%$ & $9,1 \%$ \\
\hline fev-11 & 5.892 & 5.961 & $-1,2 \%$ & $0,0 \%$ & ago-12 & 5.991 & 5.807 & $3,1 \%$ & $0,1 \%$ \\
\hline mar-11 & 5.071 & 5.954 & $-17,4 \%$ & $3,0 \%$ & set-12 & 5.112 & 5.825 & $-13,9 \%$ & $1,9 \%$ \\
\hline abr-11 & 5.591 & 5.869 & $-5,0 \%$ & $0,2 \%$ & out-12 & & 5.756 & $\alpha$ & 0,10 \\
\hline mai-11 & 5.436 & 5.842 & $-7,5 \%$ & $0,6 \%$ & nov-12 & & 10.830 & EMQ & $2,64 \%$ \\
\hline jun-11 & 5.185 & 5.803 & $-11,9 \%$ & $1,4 \%$ & & & & & \\
\hline
\end{tabular}

Fonte: O autor, (2012).

Com os dados da Tabela 22, podemos construir o Gráfico 5, onde observamos o comportamento da previsão em relação à produção real.

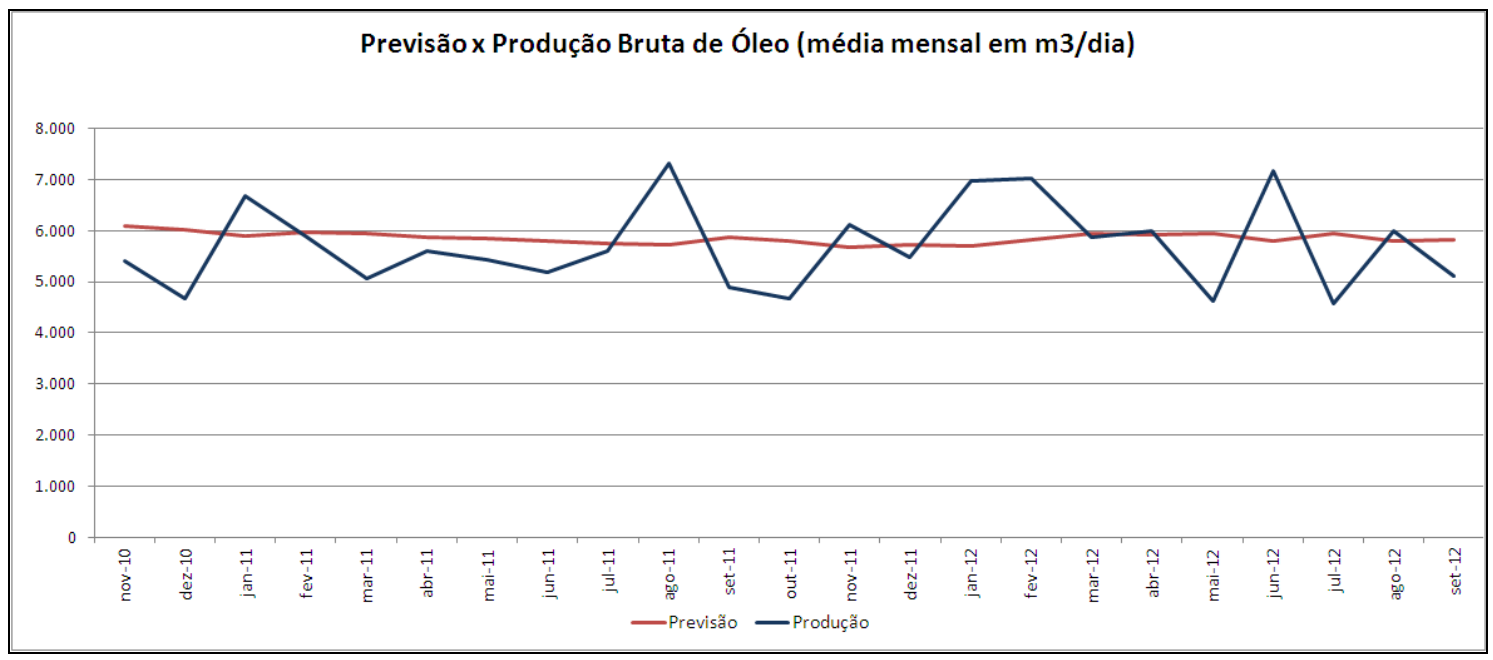

Gráfico 5 - Previsão com Amortecimento Exponencial Simples x Produção Fonte: O autor, (2012).

Através da Tabela 23 é apresentado um exemplo de dados históricos (fictícios) da produção bruta de uma determinada plataforma, onde se observa tendência de crescimento da produção. 
Tabela 23 - Dados Históricos (fictícios) da Produção Bruta - Modelo Linear

\begin{tabular}{|c|c|c|c|}
\hline Mês & $\begin{array}{c}\text { Produçãoo } \\
\text { Bruta (m3/dia) }\end{array}$ & Mês & $\begin{array}{c}\text { Produção } \\
\text { Bruta (m3/dia) }\end{array}$ \\
\hline jan-10 & 1.363 & jun-11 & 6.704 \\
\hline fev-10 & 1.423 & jul-11 & 6.996 \\
\hline mar-10 & 1.540 & ago-11 & 5.717 \\
\hline abr-10 & 1.600 & set-11 & 6.359 \\
\hline mai-10 & 1.644 & out-11 & 6.589 \\
\hline jun-10 & 1.537 & nov-11 & 7.554 \\
\hline jul-10 & 1.509 & dez-11 & 9.261 \\
\hline ago-10 & 2.622 & jan-12 & 9.606 \\
\hline set-10 & 2.488 & fev-12 & 9.277 \\
\hline out-10 & 2.413 & mar-12 & 8.870 \\
\hline nov-10 & 4.385 & abr-12 & 7.654 \\
\hline dez-10 & 4.397 & mai-12 & 9.190 \\
\hline jan-11 & 4.395 & jun-12 & 9.345 \\
\hline fev-11 & 4.227 & jul-12 & 10.128 \\
\hline mar-11 & 3.974 & ago-12 & 10.678 \\
\hline abr-11 & 4.038 & set-12 & 11.987 \\
\hline mai-11 & 5.660 & \multicolumn{3}{|c}{} \\
\cline { 1 - 3 } & \multicolumn{3}{|c}{}
\end{tabular}

Fonte: O autor, (2012).

O Gráfico 6 apresenta a tendência de crescimento da produção correspondente aos dez primeiros meses da amostra da Tabela 23, onde é explicitada a equação do gráfico, que será utilizada para se iniciar a previsão da produção. A partir desta equação, obtêm-se as estimativas iniciais de $b_{10}$ $(=132,95)$ e $a_{10}(=1.082,7+10 \times 132,95=2.412,20)$.

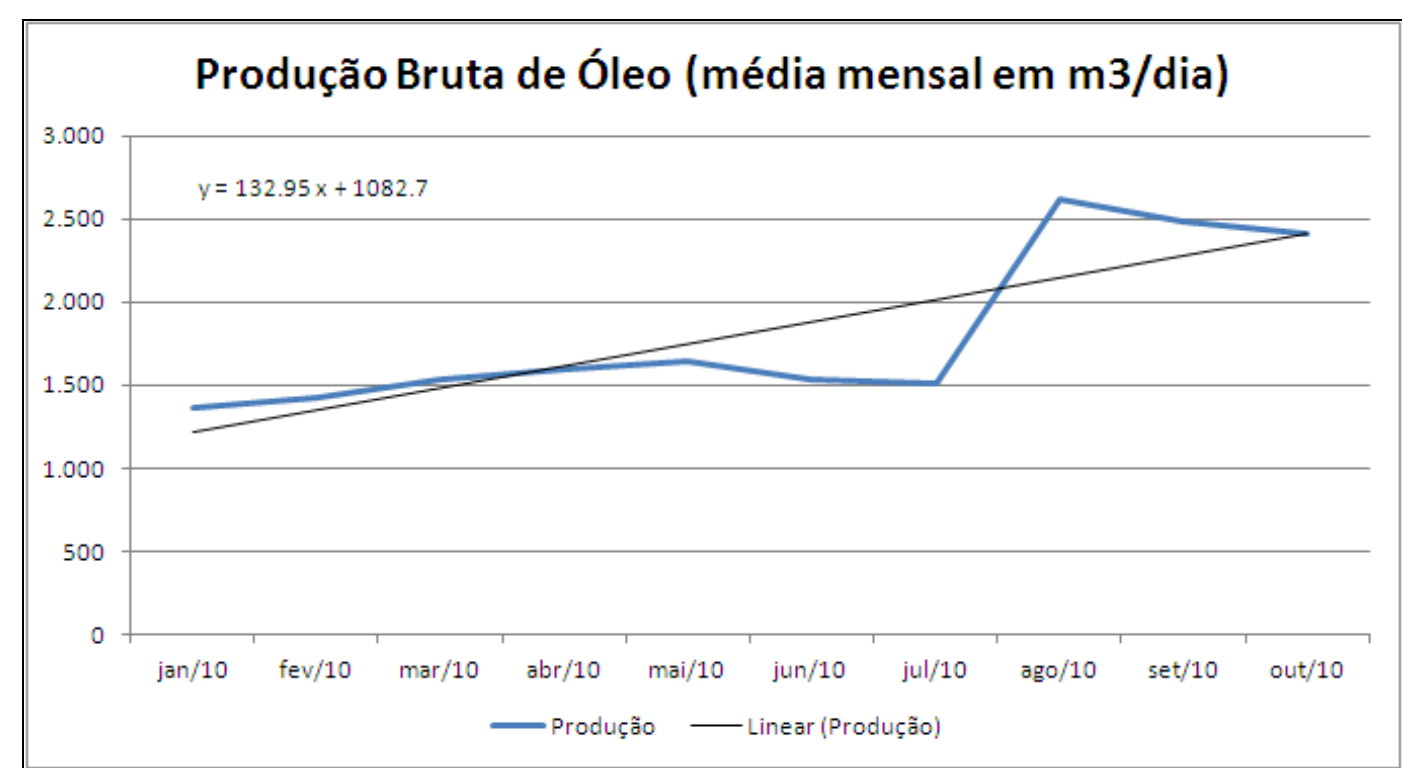

Gráfico 6 - Produção com Linha de Tendência Fonte: O autor, (2012).

A seguir é apresentada a simulação das previsões de produção para os dois meses seguintes (out-12 e nov-12), de acordo com o modelo linear, utilizando-se o 
método de amortecimento exponencial duplo, e o erro médio quadrático correspondente.

- Método de Amortecimento Exponencial Duplo: As constantes de amortecimento ( $\alpha$ e $\beta$ ) foram escolhidas através da ferramenta solver, do Microsoft Excel, de modo a minimizar o erro médio quadrático (EMQ), conforme apresentado através da Tabela 24, que foi de $2,53 \%$.

Tabela 24 - Simulação da Previsão de Produção e do Erro Médio Quadrático (EMQ) Amortecimento Exponencial Duplo

\begin{tabular}{|c|c|c|c|c|c|c|c|c|c|c|c|c|c|c|c|}
\hline Mês & $\begin{array}{c}\text { Produção } \\
\text { Bruta (m3/dia) }\end{array}$ & $a_{t}$ & $b_{t}$ & $a_{t}+b_{t}$ & Previsão & Erro\% & \begin{tabular}{|c|} 
Erro \\
Quadrático
\end{tabular} & Mês & $\begin{array}{c}\text { Produçäo } \\
\text { Bruta (m3/dia) }\end{array}$ & $a_{t}$ & $b_{t}$ & $a_{t}+b_{t}$ & Previsão & Erro\% & $\begin{array}{c}\text { Erro } \\
\text { Quadrático }\end{array}$ \\
\hline jan-10 & 1.363 & & & & & & & jul-11 & 6.996 & 6.275 & 348 & 6.623 & 5.966 & $14,7 \%$ & $2,2 \%$ \\
\hline fev-10 & 1.423 & & & & & & & ago-11 & 5.717 & 6.351 & 315 & 6.666 & 6.623 & $-15,9 \%$ & $2,5 \%$ \\
\hline mar-10 & 1.540 & & & & & & & set-11 & 6.359 & 6.574 & 303 & 6.877 & 6.666 & $-4,8 \%$ & $0,2 \%$ \\
\hline abr-10 & 1.600 & & & & & & & out-11 & 6.589 & 6.791 & 293 & 7.083 & 6.877 & $-4,4 \%$ & $0,2 \%$ \\
\hline mai-10 & 1.644 & & & & & & & nov-11 & 7.554 & 7.224 & 310 & 7.534 & 7.083 & $6,2 \%$ & $0,4 \%$ \\
\hline jun-10 & 1.537 & & & & & & & dez-11 & 9.261 & 8.052 & 374 & 8.426 & 7.534 & $18,6 \%$ & $3,5 \%$ \\
\hline jul-10 & 1.509 & & & & & & & jan-12 & 9.606 & 8.780 & 417 & 9.198 & 8.426 & $12,3 \%$ & $1,5 \%$ \\
\hline ago $\cdot 10$ & 2.622 & & & & & & & fev-12 & 9.277 & 9.221 & 420 & 9.642 & 9.198 & $0,9 \%$ & $0,0 \%$ \\
\hline set-10 & 2.488 & & & & & & & mar-12 & 8.870 & 9.410 & 392 & 9.802 & 9.642 & $-8,7 \%$ & $0,8 \%$ \\
\hline out-10 & 2.413 & $2.412,20$ & 132,95 & 2.545 & & & & abr-12 & 7.654 & 9.157 & 312 & 9.470 & 9.802 & $-28,1 \%$ & $7,9 \%$ \\
\hline nov-10 & 4.385 & $3.097,02$ & 200,88 & 3.298 & 2.545 & $42,0 \%$ & $17,6 \%$ & mai-12 & 9.190 & 9.386 & 302 & 9.688 & 9.470 & $-3,1 \%$ & $0,1 \%$ \\
\hline dez-10 & 4.397 & $3.627,71$ & 241,48 & 3.869 & 3.298 & $25,0 \%$ & $6,3 \%$ & $\begin{array}{l}\text { jun-12 } \\
\end{array}$ & 9.345 & 9.585 & 289 & 9.874 & 9.688 & $-3,7 \%$ & $0,1 \%$ \\
\hline jan-11 & 4.395 & $4.026,83$ & 260,88 & 4.288 & 3.869 & $12,0 \%$ & $1,4 \%$ & jul-12 & 10.128 & 9.950 & 299 & 10.249 & 9.874 & $2,5 \%$ & $0,1 \%$ \\
\hline fev-11 & 4.227 & $4.269,56$ & 258,65 & 4.528 & 4.288 & $-1,4 \%$ & $0,0 \%$ & ago.12 & 10.678 & 10.378 & 315 & 10.693 & 10.249 & $4,0 \%$ & $0,2 \%$ \\
\hline mar-11 & 3.974 & $4.361,90$ & 238,18 & 4.600 & 4.528 & $-14,0 \%$ & $1,9 \%$ & set-12 & 11.987 & 11.081 & 362 & 11.443 & 10.693 & $10,8 \%$ & $1,2 \%$ \\
\hline abr-11 & 4.038 & $4.431,45$ & 217,42 & 4.649 & 4.600 & $-13,9 \%$ & $1,9 \%$ & out-12 & & & & & 11.443 & $\alpha$ & 0,30 \\
\hline mai-11 & 5.660 & $4.952,33$ & 254,77 & 5.207 & 4.649 & $17,9 \%$ & $3,2 \%$ & nov-12 & & & & & 11.443 & $\beta$ & 0,12 \\
\hline jun-11 & 6.704 & 5.656 & 310,04 & 5.966 & 5.207 & $22,3 \%$ & $5,0 \%$ & & & & & & & EMQ & $2,53 \%$ \\
\hline
\end{tabular}

Fonte: O autor, (2012).

Com os dados da Tabela 24, podemos construir o Gráfico 7, onde observamos o comportamento da previsão em relação à produção real.

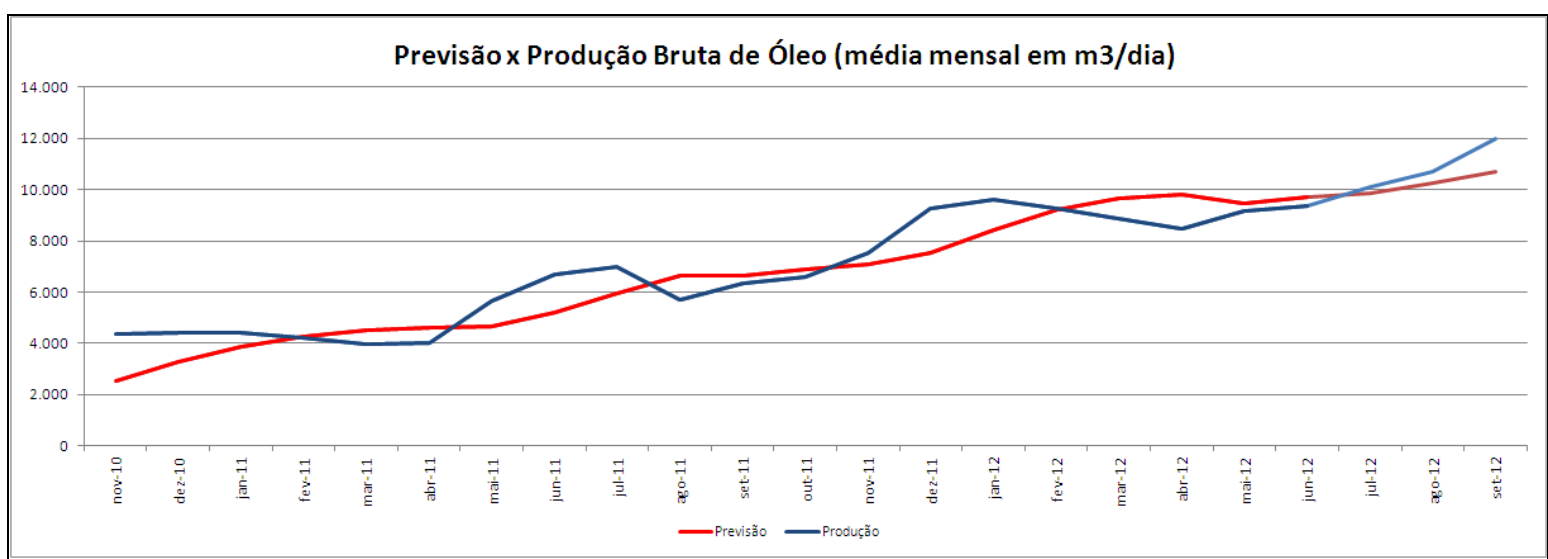

Gráfico 7 - Previsão com Amortecimento Exponencial Duplo x Produção Fonte: O autor, (2012). 


\subsubsection{2}

Projetar Qualidade

Através da Figura 15 é apresentado o fluxograma das atividades do processo Projetar Qualidade.

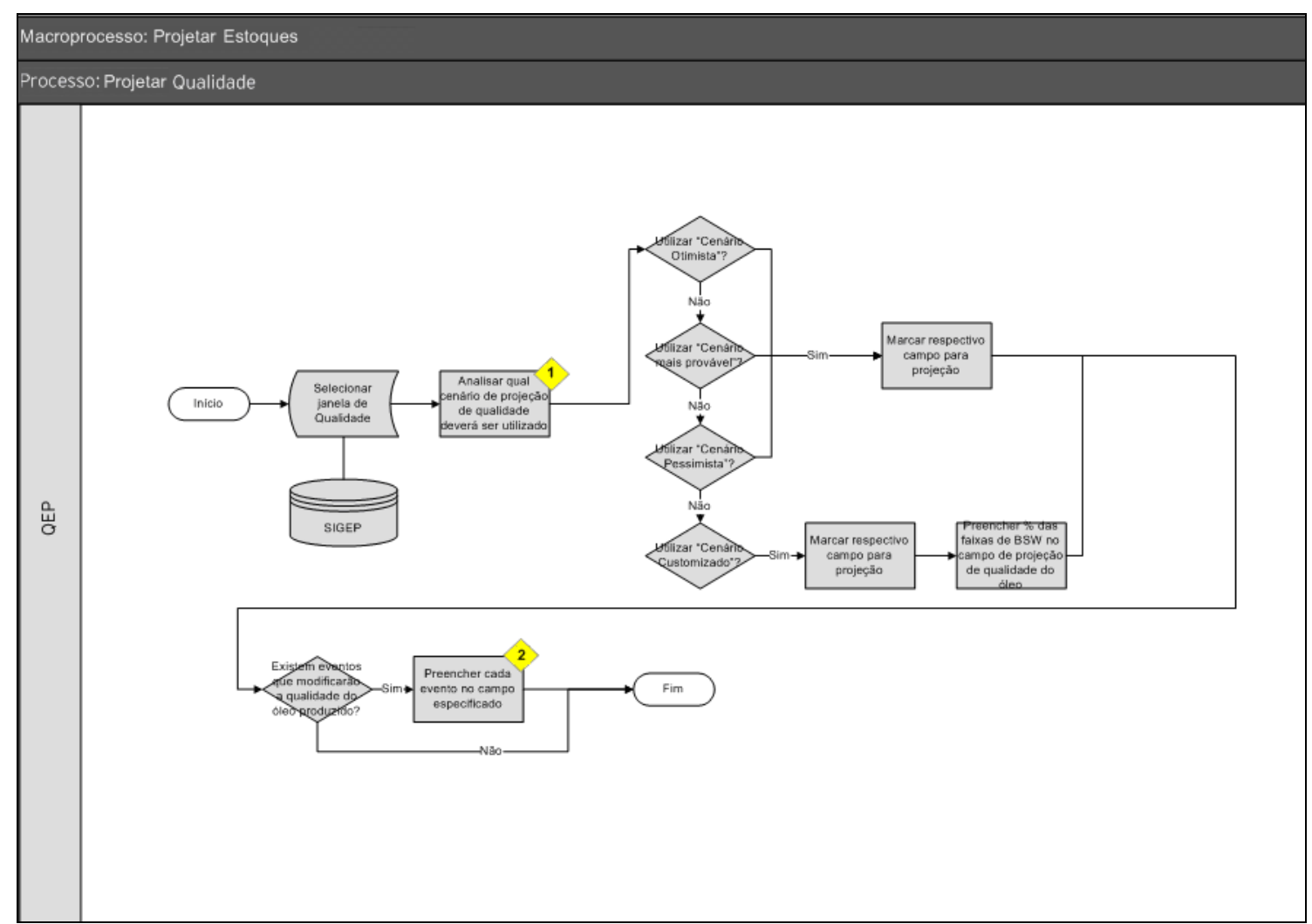

Figura 15 - Fluxograma do processo Projetar Qualidade

Fonte: O autor, (2012).

A gerência de Qualidade e Estoque de Produtos (QEP) deve selecionar um dos três cenários de projeção de qualidade disponíveis.

- “Cenário Mais Provável”: é o cenário que, com base nos dados históricos, melhor retrata o desempenho histórico das plantas de processamento de petróleo do $\mathrm{F}(\mathrm{P}) \mathrm{SO}$ com relação à sua especificação em teores $(\%)$ de BSW;

- "Cenário Otimista": este cenário retrata, com base nos dados históricos, o mês de melhor desempenho no processamento de petróleo do $\mathrm{F}(\mathrm{P}) \mathrm{SO}$, levando em consideração a amostra dos dados históricos;

- "Cenário Pessimista": é o oposto do cenário acima, ou seja, retrata o mês de pior desempenho no processamento de petróleo do $\mathrm{F}(\mathrm{P}) \mathrm{SO}$, levando em consideração a amostra dos dados históricos; 
- "Cenário Customizado": caso seja analisada a projeção dos cenários acima e se chegue à conclusão de que a mesma não representa a realidade atual de operação do $\mathrm{F}(\mathrm{P}) \mathrm{SO}$ em questão, este cenário é utilizado para se definir os percentuais dos fluidos da produção bruta que serão armazenados nos tanques. Esta opção também pode ser utilizada para simular diferentes cenários, de modo a auxiliar na análise de risco de envio de óleo desenquadrado ou água para o Abastecimento, para que sejam tomadas as ações cabíveis de forma proativa.

No campo "Eventos de Qualidade" devem ser registrados todos os eventos determinísticos que influenciam o desempenho do processamento do petróleo, as datas de início e fim de cada evento e o teor de BSW (percentuais pré-definidos) do petróleo a ser produzido durante este período. Estes valores serão utilizados para projetar a qualidade do petróleo a ser produzido no período indicado e serão prioritários em relação ao cenário selecionado no item 1, conforme ilustrado através da Tabela 25.

Tabela 25 - Exemplo (dados fictícios) de Projeção de Distribuição da Produção de Petróleo por faixa de qualidade considerando Eventos Determinísticos

\begin{tabular}{|c|c|c|c|c|}
\hline \multicolumn{5}{|c|}{ Projeção de Qualidade do Óleo (em \%) } \\
\hline $\mathrm{BSW}<0,5 \%$ & $0 \%$ & \multicolumn{2}{|c|}{ BSW entre 1 e $5 \%$} & $18 \%$ \\
\hline \multirow[t]{2}{*}{ BSW entre 0,5 e $1 \%$} & $75 \%$ & \multicolumn{2}{|l|}{$B S W>5 \%$} & $7 \%$ \\
\hline & & \multicolumn{2}{|c|}{ Total } & $100 \%$ \\
\hline \multicolumn{5}{|c|}{ Eventos Qualidade } \\
\hline Evento & Data Início & Data Fim & \multicolumn{2}{|c|}{ BSW } \\
\hline Manutenção Permutador & $10 /$ mai & $20 /$ mai & \multicolumn{2}{|c|}{ BSW entre 1 e $5 \%$} \\
\hline \multicolumn{5}{|c|}{ Projeção Maio/2012 } \\
\hline Data & $\mathrm{BSW}<0,5 \%$ & $\begin{array}{c}\text { BSW entre } \\
0,5 \text { e } 1 \%\end{array}$ & $\begin{array}{c}\text { BSW } \\
\text { entre } 1 \text { e } 5 \%\end{array}$ & $\mathrm{BSW}>5 \%$ \\
\hline Entre 1 e $9 / 5$ & $0 \%$ & $75 \%$ & $18 \%$ & $7 \%$ \\
\hline Entre 10 e $20 / 5$ & $0 \%$ & $0 \%$ & $100 \%$ & $0 \%$ \\
\hline Entre 21 e $31 / 5$ & $0 \%$ & $75 \%$ & $18 \%$ & $7 \%$ \\
\hline
\end{tabular}

Fonte: O autor, (2012).

É apresentada, através da Figura 16, a tela de entrada de dados de qualidade do sistema SIGEP para preenchimento dos dados e escolha do cenário de qualidade do óleo produzido. 


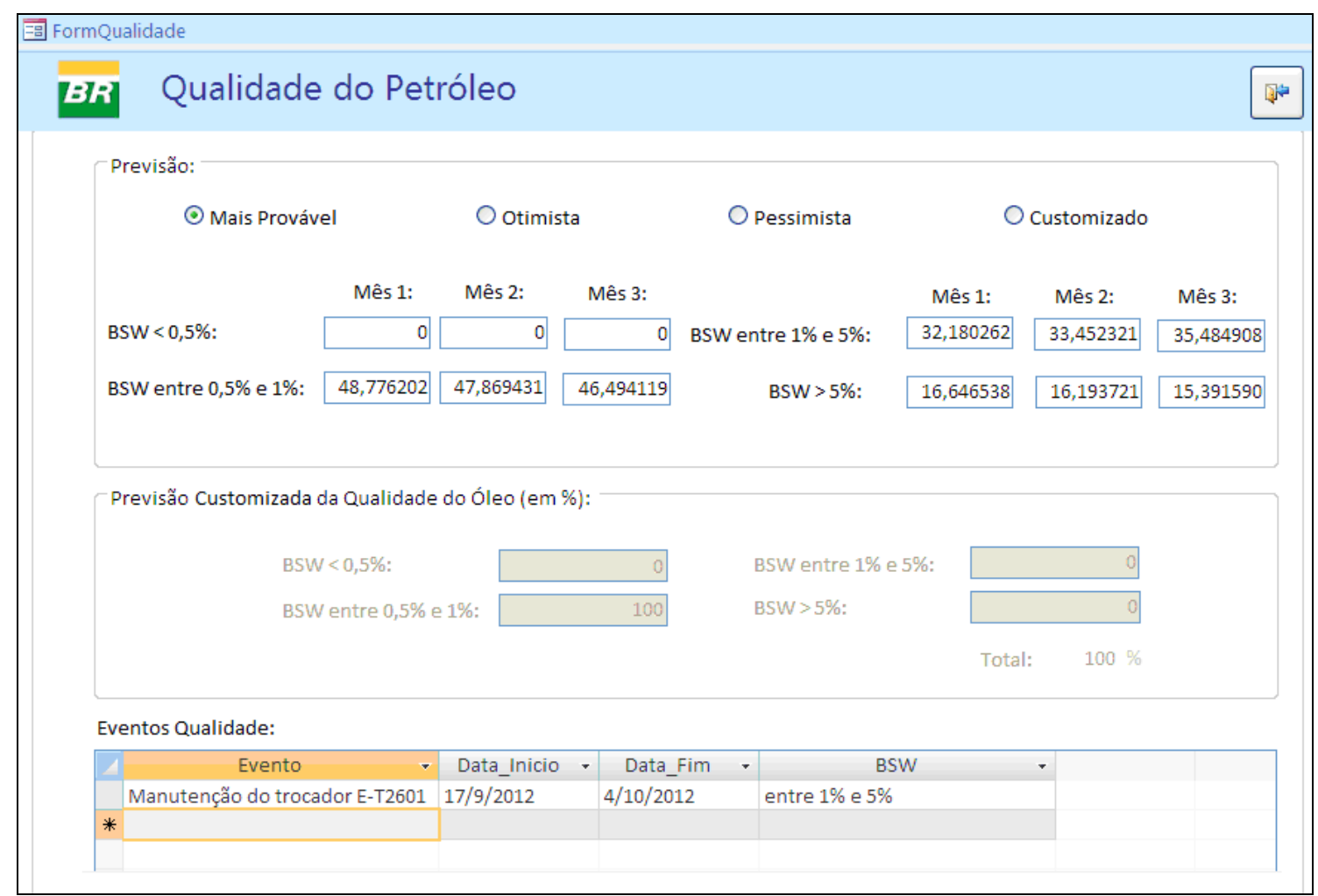

Figura 16 - Tela de Entrada de Dados de Qualidade do Sistema de Gestão de Estoque de Petróleo Fonte: O autor, (2012).

A modelagem do comportamento dos estoques e da qualidade dos fluidos no simulador, que está em fase de desenvolvimento, deverá seguir o diagrama esquemático representado através da Figura 17, que, de forma simplificada, representa este comportamento, cujo detalhamento é descrito em seguida.

A produção dos poços submarinos chega à superfície da plataforma com óleo, água e gás e, após passar por mais de um estágio de separação destes fluidos, os mesmos seguem caminhos diferentes. Parte do gás produzido é consumida na própria plataforma como gás combustível, principalmente para geração de energia elétrica para o processo de compressão de gás, com o intuito de transferi-lo até o continente ou para a injeção de gás lift. Outra parcela é utilizada para injeção na capa, com o objetivo de manter a pressão do reservatório e maximizar a recuperação final de óleo do reservatório; ou para injeção de gás lift, que é o gás comprimido a alta pressão e injetado na coluna de produção de petróleo em uma determinada profundidade para promover a elevação artificial, isto é, para diminuir o gradiente de pressão da coluna de óleo, com o objetivo de aumentar a produção de óleo. A parte do gás que não é consumida internamente ou por outra plataforma (através de transporte dutoviário) e nem é injetada, é escoada através de gasodutos para o continente para o seu processamento, distribuição e venda. Se 
não houver capacidade suficiente para escoar todo o gás e se houver saldo de gás após o uso na geração de energia para abastecer a plataforma ou para o processo de injeção, a única opção é queimar o gás em torres instaladas nas plataformas por motivo de segurança.

A água produzida pela plataforma passa por um processo de tratamento que visa especificá-la em teor de óleos e graxas (TOG), que constitui um dos parâmetros ambientais de maior relevância para a indústria do petróleo, e cujos limites para descarte são estabelecidos através de Resolução específica do CONAMA (Conselho Nacional do Meio Ambiente). Além da água separada nos primeiros estágios de separação dos fluidos, pode haver separação da água emulsionada ao óleo quando do seu processamento, ou através do processo de decantação nos tanques de petróleo para melhoria da sua qualidade. Em ambos os casos, esta água é enviada para a planta de tratamento para posterior descarte.

Devido a possíveis problemas operacionais nas plantas de tratamento de água ou devido a paradas (programadas ou emergenciais) para manutenções em seus equipamentos, o seu desempenho pode se afetado, vindo a acarretar que parte da água enviada para o tratamento não seja descartada por não ter atingido os limites exigidos pelo órgão regulador, havendo necessidade de armazená-la em tanques específicos. Após o retorno do desempenho da planta de tratamento, esta água deve ser reenviada para tratamento e posterior descarte.

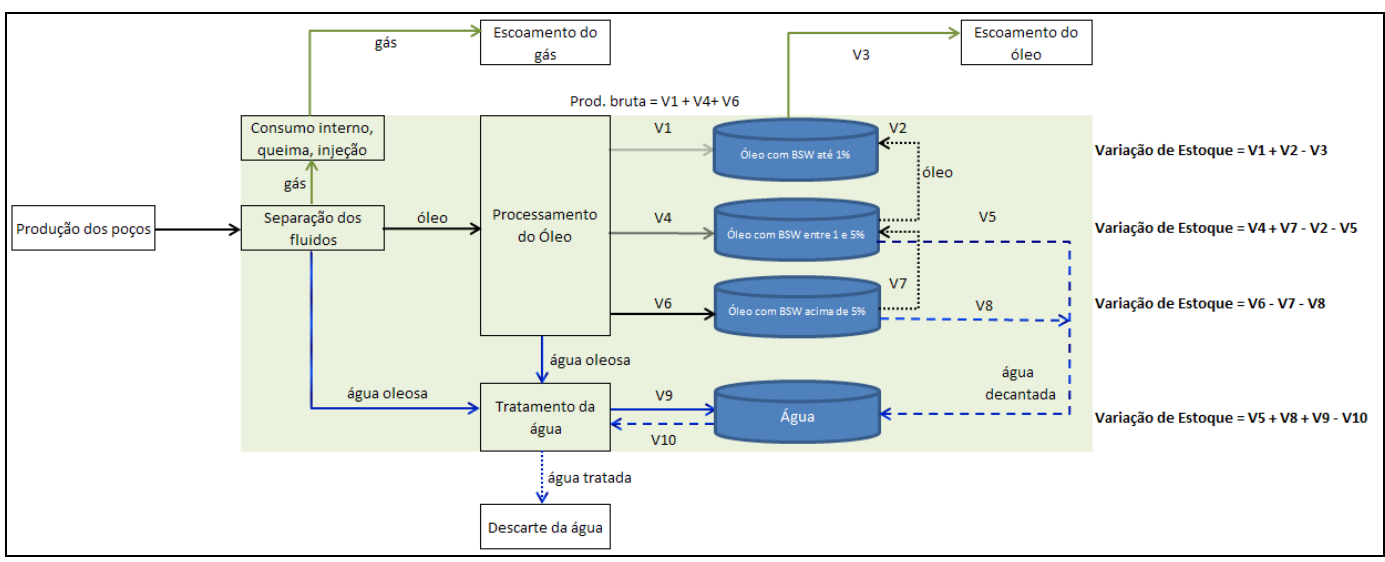

Figura 17 - Diagrama Esquemático (simplificado) da Produção de Petróleo Fonte: O autor, (2012).

Já o óleo separado nos primeiros estágios de separação dos fluidos é todo enviado para a planta de processamento, com o objetivo de reduzir o teor (\%) de água e sedimentos emulsionados ao petróleo (BSW). Em geral, e para a simplificação deste estudo, convencionou-se que as plataformas direcionam toda a 
produção bruta de petróleo (óleo + água emulsionada) para os tanques de acordo com a seguinte classificação: óleo especificado = "óleo com BSW até 0,5\% ou 1\% de BSW" - a depender do projeto da plataforma ou da especificação do cliente; óleo fora da especificação ou desenquadrado (considerado produto semi-acabado) de baixo BSW = "óleo com BSW entre 1\% e 5\%"; e óleo fora de especificação ou desenquadrado (considerado produto semi-acabado) com alto teor de $\mathrm{BSW}=$ "óleo com BSW acima de 5\%".

Em tese, as plataformas deveriam desempenhar de tal forma que o óleo fosse todo produzido de acordo com as especificações. Porém, devido a possíveis problemas operacionais nas plantas de processamento do óleo ou devido a paradas (programadas ou emergenciais) para manutenções em seus equipamentos, o seu desempenho pode se afetado, acarretando no seu desenquadramento e havendo necessidade de segregar este óleo para decantação e posterior envio da água depositada no fundo do tanque para os tanques de água.

Para reduzir o acúmulo de estoque de óleo desenquadrado nos tanques da plataforma, há necessidade de aguardar a decantação da água emulsionada ao óleo, mantendo o óleo armazenado no tanque durante dias, a depender da sua densidade, para posterior raspagem (remoção através da sucção efetuada por bombas) da água acumulada no fundo do tanque, até a redução do BSW aos níveis adequados. Este procedimento deve ser efetuado até o retorno da planta de processamento do óleo às condições normais de operação.

A Figura 17 retrata de forma simplificada todo este fluxo e apresenta também as equações das variações de estoque de cada fluido. A modelagem do simulador deverá levar em consideração os dados históricos e a aleatoriedade do processo para determinar para os seguintes valores para o período projetado:

- os percentuais da produção bruta diária que corresponderão a cada parcela de óleo produzido de acordo com a classificação descrita acima, baseando-se no desempenho histórico das plantas de processamento de óleo. Este cálculo será utilizado para escolha dos cenários de qualidade (mais provável, otimista ou pessimista) e determinarão os valores de V1, V4 e V6;

- a taxa de decantação do óleo para que sejam projetadas as migrações dos volumes de óleo entre seus tanques, de acordo com a sua classificação de qualidade, de modo a calcular V2 e V7; e para que sejam projetados os volumes 
de água que serão decantados e migrados para o tanque de água, de modo a calcular V5 e V8.

- o desempenho do tratamento da água, baseando-se no seu no desempenho histórico, de maneira a calcular V9 e V10. Ou seja, se houver capacidade ociosa, a planta de tratamento receberá um volume V10 para tratamento. Em caso contrário, será enviado para tanque de água um volume V9.

Vale ressaltar que o V3, volume de óleo que será escoado, dependerá do porte do navio aliviador selecionado.

\subsubsection{3}

Projetar Tancagem

Através da Figura 18 é apresentado o fluxograma das atividades do processo Projetar Tancagem.

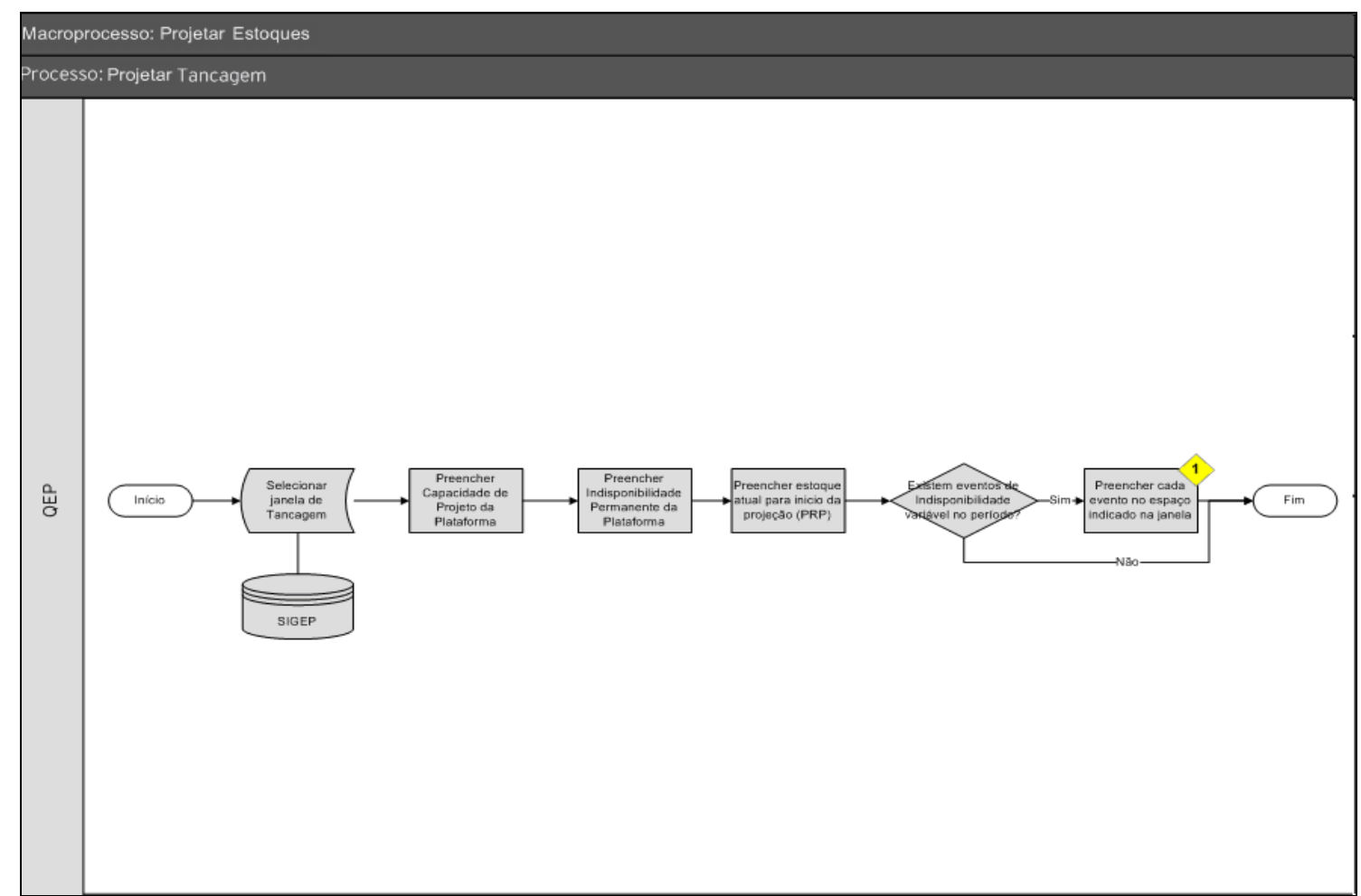

Figura 18 - Fluxograma do processo Projetar Tancagem Fonte: O autor, (2012). 
A gerência de Qualidade e Estoque de Produtos (QEP) preencherá os parâmetros de tancagem e os eventos que alteram a capacidade de tancagem da plataforma, de acordo com a Figura 19.

- "Capacidade de Projeto": capacidade de projeto do F(P)SO;

- "Indisponibilidade Permanente": por ser um navio convertido em uma plataforma de produção de petróleo, diversos equipamentos e plantas de processamento são instalados nele, aumentando o peso da embarcação e impedindo a utilização de $100 \%$ da capacidade nominal de armazenagem, o que poderia comprometer a sua estabilidade, devido aos limites de esforços estruturais, podendo levá-lo a adernar. Subtraindo a Indisponibilidade Permanente da Capacidade de Projeto, obtém-se a Capacidade Operacional, que nada mais é que a capacidade real de armazenagem do $\mathrm{F}(\mathrm{P}) \mathrm{SO}$;

- "Estoques Atuais": são os estoques iniciais da plataforma, por tipo de fluido, para que sejam projetados, a partir destes valores, os estoques futuros;

- "Indisponibilidade Variável”: redução de capacidade de armazenagem devido à manutenção e inspeção dos tanques de carga da plataforma. Pelo fato do FPSO ou FSO ser um navio convertido em plataforma, o mesmo segue as normas da marinha brasileira, que diz que todos os tanques precisam ser inspecionados para avaliação e possível manutenção a cada cinco anos. Cada vez que um dos tanques entra em manutenção, o mesmo fica fora de operação, podendo acarretar no fechamento dos tanques laterais, caso necessite de algum reparo, para que não haja passagem de óleo de um tanque para o outro. Subtraindo-se as indisponibilidades permanente e variável da capacidade de projeto chega-se à capacidade operacional da plataforma em um dado momento. Devem ser registrados então todos os eventos determinísticos que alteram a capacidade de tancagem do $\mathrm{F}(\mathrm{P}) \mathrm{SO}$ ao longo de um determinado período. Estes valores serão utilizados para projetar a capacidade de armazenagem da plataforma no período indicado. Os campos de preenchimento desta variável são: Evento, Data de Início, Data de Fim e Variação. A coluna da direita é calculada através da soma da capacidade operacional com a variação de tancagem definida em cada evento. 


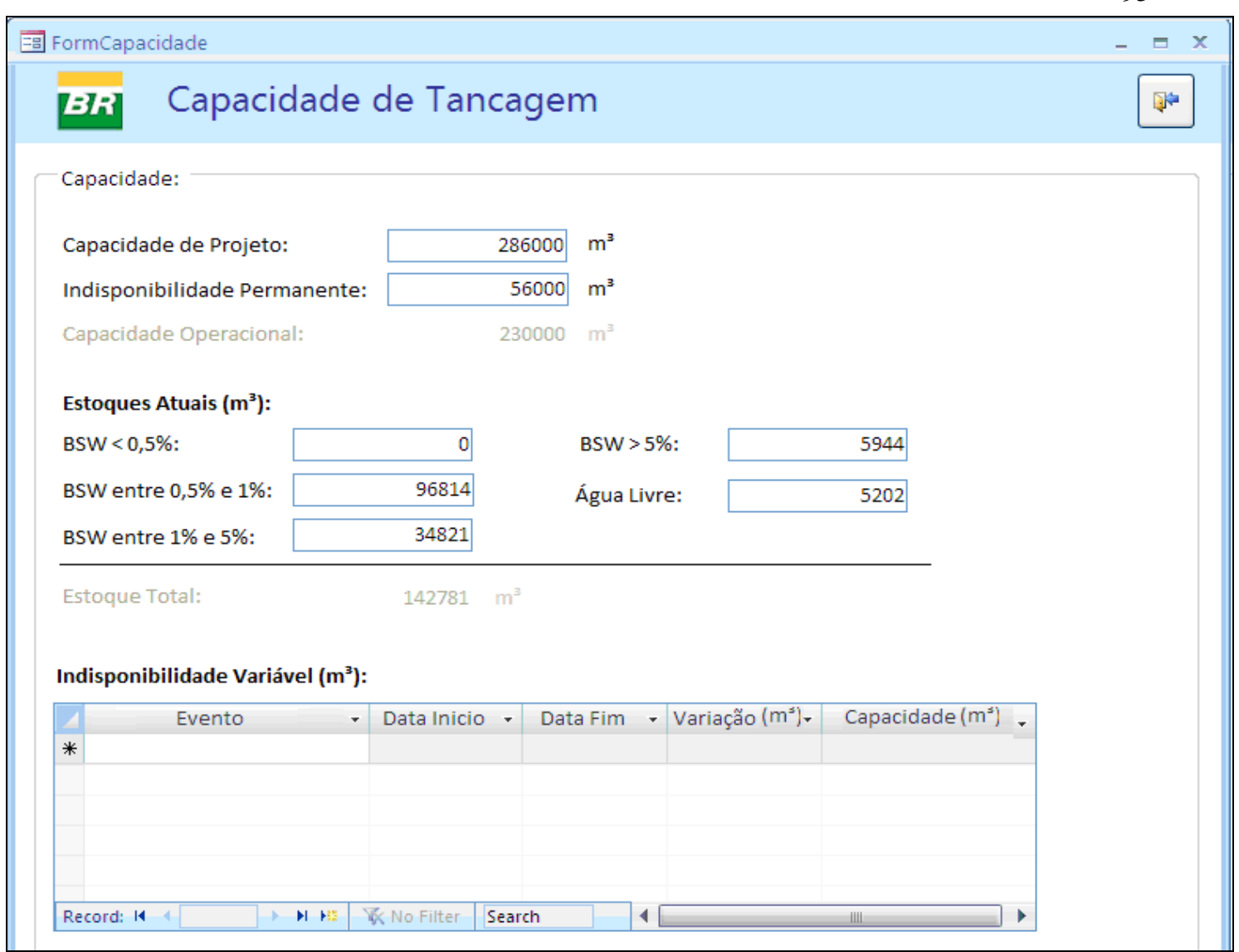

Figura 19 - Tela de Entrada de Dados de Tancagem do Sistema de Gestão de Estoque de Petróleo Fonte: O autor, (2012).

Através da Tabela 26, é apresentado um exemplo dos cálculos da capacidade operacional (= capacidade de projeto - indisponibilidade permanente) e de capacidade durante o evento determinístico (= capacidade operacional + variação).

Tabela 26 - Exemplo de Cálculo de Capacidade Operacional considerando Eventos Determinísticos

\begin{tabular}{|c|c|c|c|c|}
\hline Capacidade de Projeto & 286.000 & & & \\
\hline Indisponibilidade Permanente & 56.000 & 13 & & \\
\hline Capacidade Operacional & 230.000 & & & \\
\hline Evento & Data Início & Data Fim & Variaçäo & Capacidade \\
\hline Manutençẫo da Tanque C-2 & $10 /$ mai & $20 /$ mai & -20.000 & 210.000 \\
\hline
\end{tabular}

Fonte: O autor, (2012). 
4.2.2.4

Projetar Lastro

Através da Figura 20 é apresentado o fluxograma das atividades do processo Projetar Lastro.

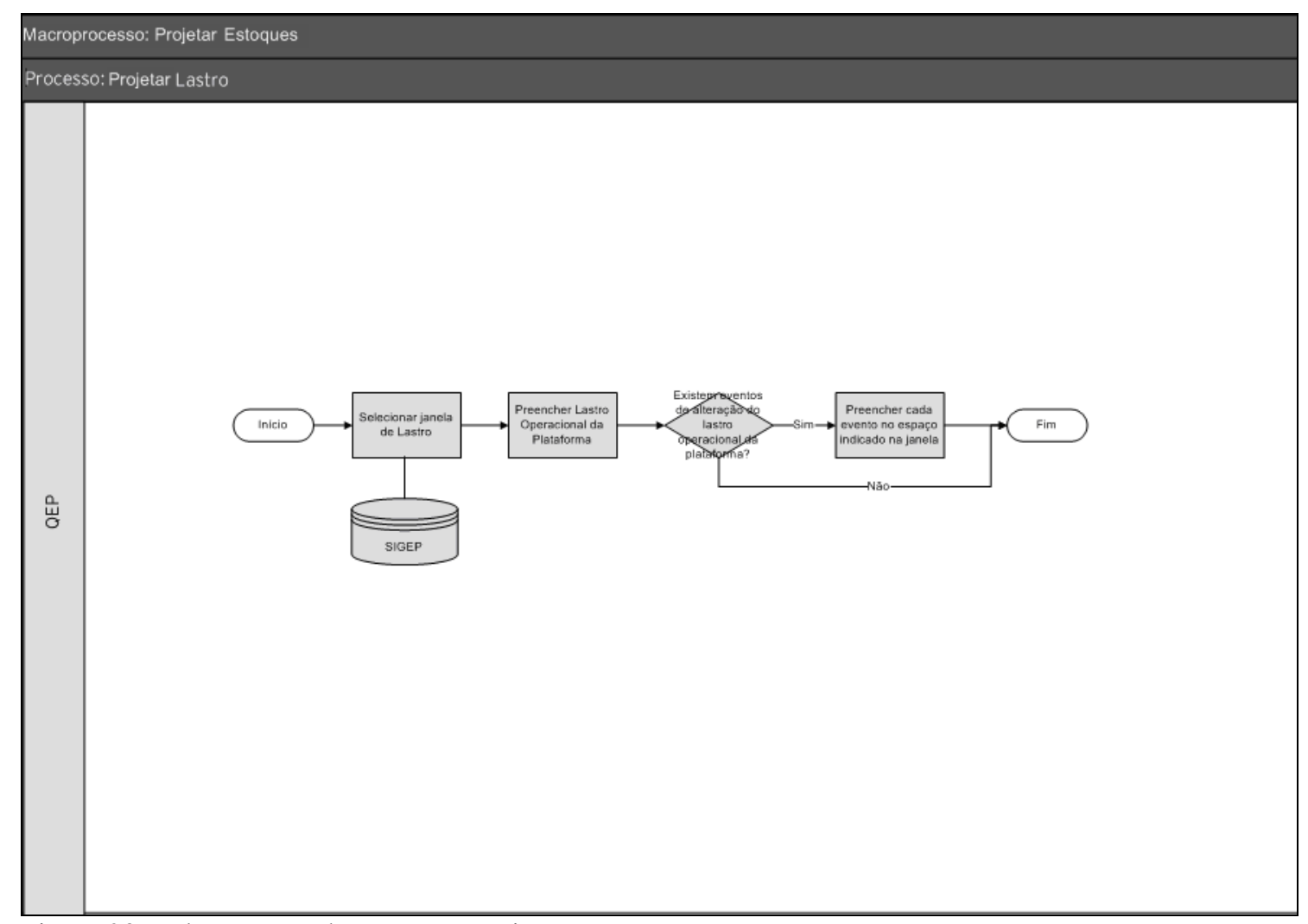

Figura 20 - Fluxograma do processo Projetar Lastro

Fonte: O autor, (2012).

A gerência de Qualidade e Estoque de Produtos (QEP) deve preencher os parâmetros de Lastro Operacional e os eventos de variação do mesmo.

- "Lastro Operacional": lastro mínimo para a operação do F(P)SO;

- "Eventos de Lastro": são registrados todos os eventos determinísticos que alteram o lastro do $\mathrm{F}(\mathrm{P}) \mathrm{SO}$ ao longo de um determinado período. Os campos Evento, Data de Início, Data de Fim e Variação apresentados através da Figura 21 são preenchidos e a coluna da direita é calculada através da soma do lastro operacional com a variação de lastro de cada evento, similar ao cálculo da capacidade operacional levando em consideração os eventos determinísticos. 


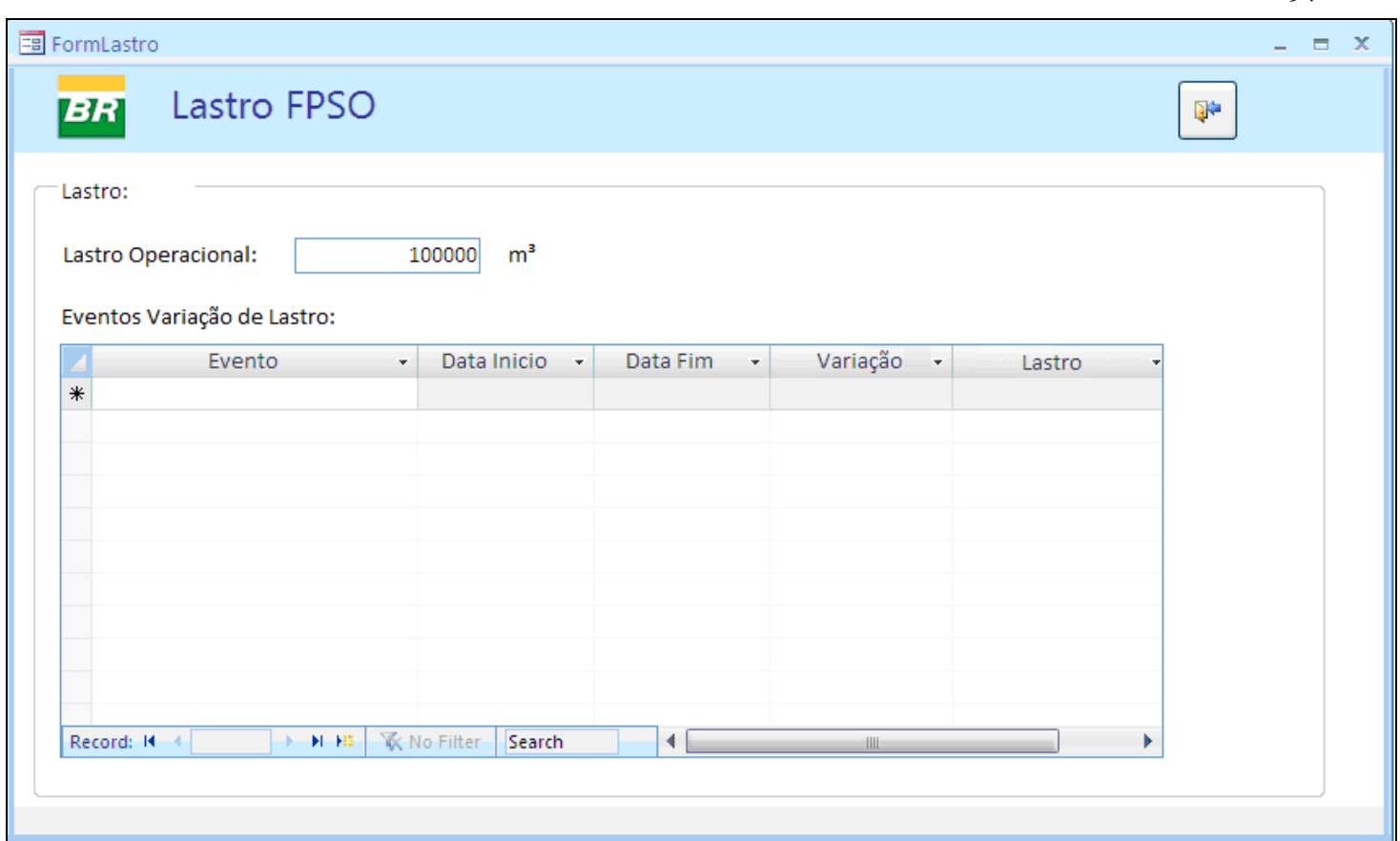

Figura 21 - Tela de Entrada de Dados de Lastro do Sistema de Gestão de Estoque de Petróleo (SIGEP)

Fonte: O autor, (2012).

\section{2 .2 .5}

Projetar Dados de Offloading

Através da Figura 22 é apresentado o fluxograma das atividades do processo Projetar Dados de Offloading. 


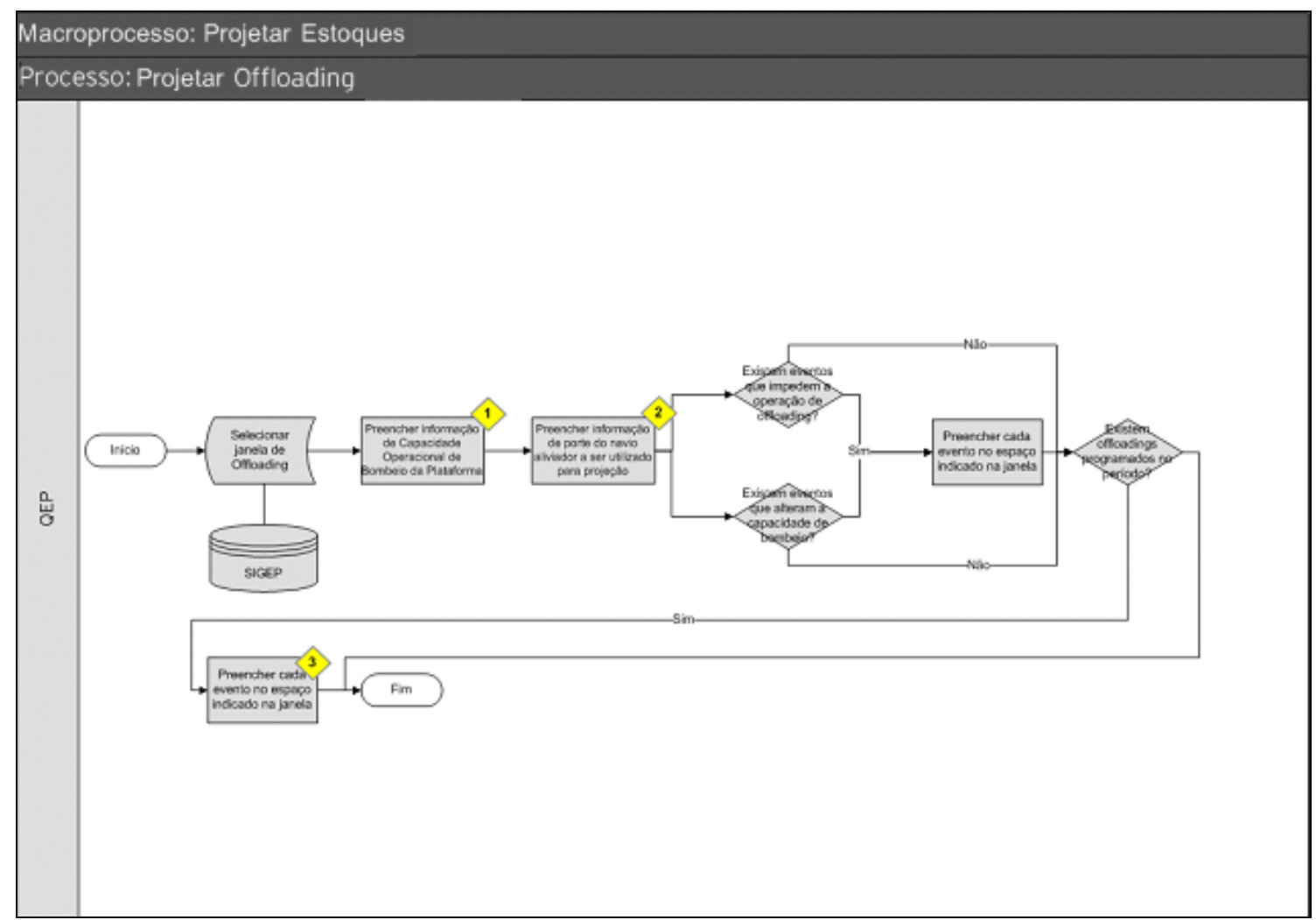

Figura 22 - Fluxograma do processo Projetar Dados de Offloading Fonte: $\mathrm{O}$ autor, (2012).

A gerência de Qualidade e Estoque de Produtos (QEP) deve preencher a capacidade operacional de bombeio do FPSO, de acordo com a Figura 23. Se, durante a projeção ou simulação, não houver nenhum evento de variação de capacidade de bombeio registrado, este será o valor utilizado;

Deve ser preenchido o campo "Lote de Retirada", que define o porte do navio aliviador. O ideal é simular projeções de estoque para cada tipo de navio e decidir pelo cenário de projeção que melhor atenda aos objetivos de negócio da empresa, às restrições operacionais e, se possível, à otimização dos estoques das plataformas no período projetado. Caso este campo não seja preenchido, as projeções considerarão lotes de retirada que minimizem o custo total da operação, levando em consideração o custo de oportunidade do capital investido no estoque e o custo de transporte. A análise dos cenários e a seleção da melhor alternativa serão detalhadas no item 4.2.2.6 - Analisar Cenários e Selecionar Melhor Projeção;

Nos campo de Eventos de Offloading devem ser registrados todos os eventos que impedem a operação de offloading, os que alteram a vazão de bombeio e os offloadings programados. 
- Eventos de Impedimento de Offloading: eventos de impedimento de offloading, com data início e data fim. Estas datas não serão consideradas para retirada de petróleo na projeção dos estoques;

- Eventos de Variação de Capacidade de Bombeio: eventos que alteram a capacidade de bombeio de petróleo da plataforma para o navio. Possui como entrada os campos: "Evento", "Data Início", "Data Fim" e "Variação de bombeio". A coluna "Bombeio" é calculada através da soma da capacidade de bombeio com a variação informada;

- Offloadings Programados: offloadings programados, com data de início e o lote a ser transferido.

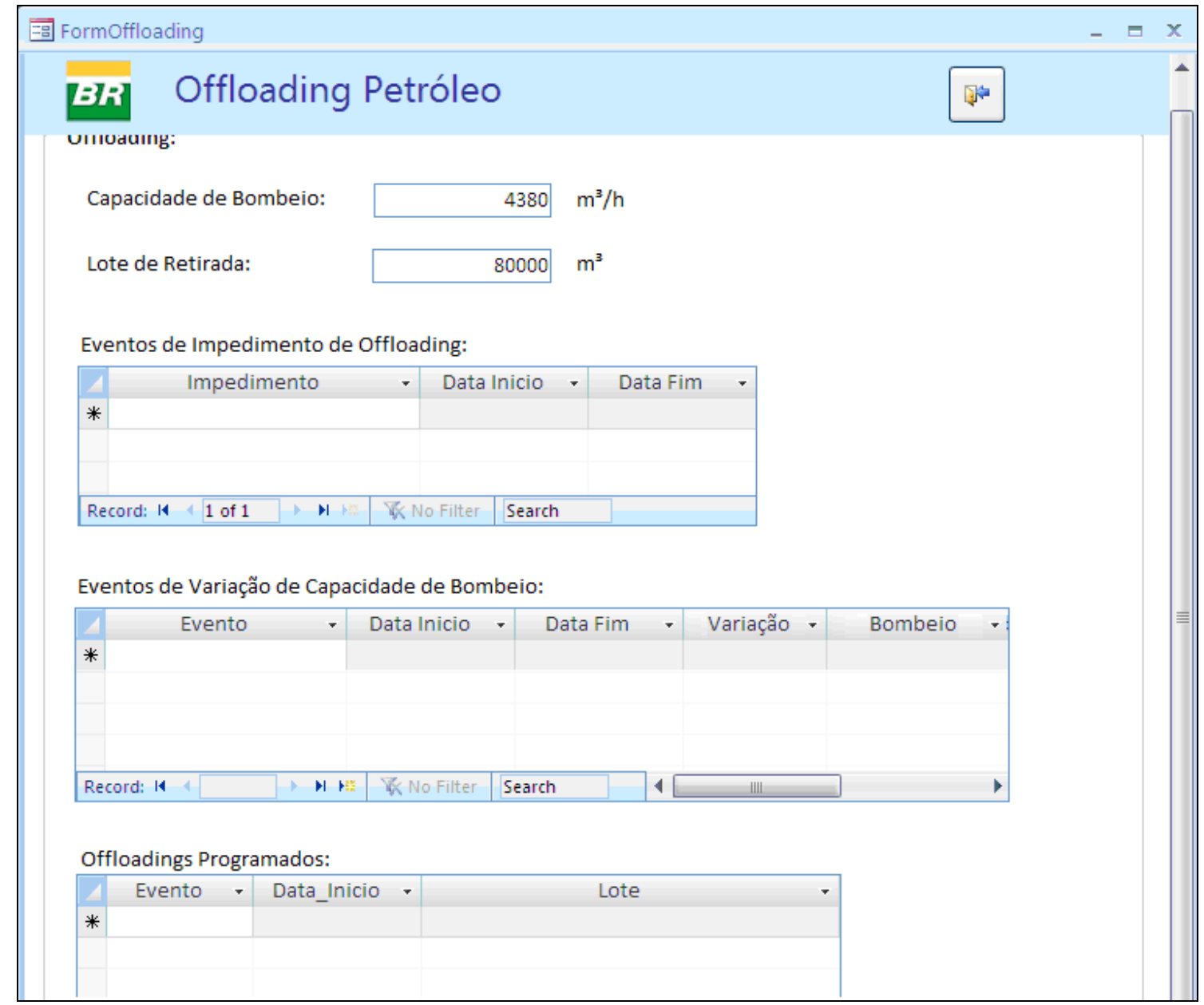

Figura 23 - Tela de Entrada de Dados de Offloading do Sistema de Gestão de Estoque de Petróleo Fonte: O autor, (2012). 


\subsubsection{6}

Analisar Cenários e Selecionar Melhor Projeção

Os estoques devem ser projetados mais de uma vez a cada ciclo do planejamento tático, de forma que sejam comparados os diferentes cenários e que seja selecionado o cenário de projeção que melhor atenda aos objetivos de negócio da empresa, às restrições operacionais e, se possível, à otimização dos estoques das plataformas no período projetado. Quanto mais se exercitar a projeção e a análise de cenários, mais robusto será o processo e melhor será a definição dos níveis de estoque e dos lotes de retirada.

Para cada cenário, deverão ser efetuadas projeções de acordo com cada porte de navio disponível na frota atual da empresa, de modo a identificar o tipo de navio que minimiza os custos totais das operações, considerando os custos de oportunidade do óleo armazenado e os custos de transporte de cada navio. A partir da escolha do tipo de navio, o lote ideal para transferência é definido automaticamente, de acordo com a capacidade de armazenagem do navio selecionado.

É importante destacar que, durante a análise de cenários, questionamentos deverão ser feitos a respeito das possíveis ineficiências dos processos e de situações indesejadas, devendo ser criados planos de ação e situações de contorno para evitá-las. Nesta etapa do processo, a análise de riscos pode ser muito utilizada.

Através da Figura 24 é apresentado o fluxograma das atividades do processo Analisar Cenários e Selecionar Melhor Projeção. 


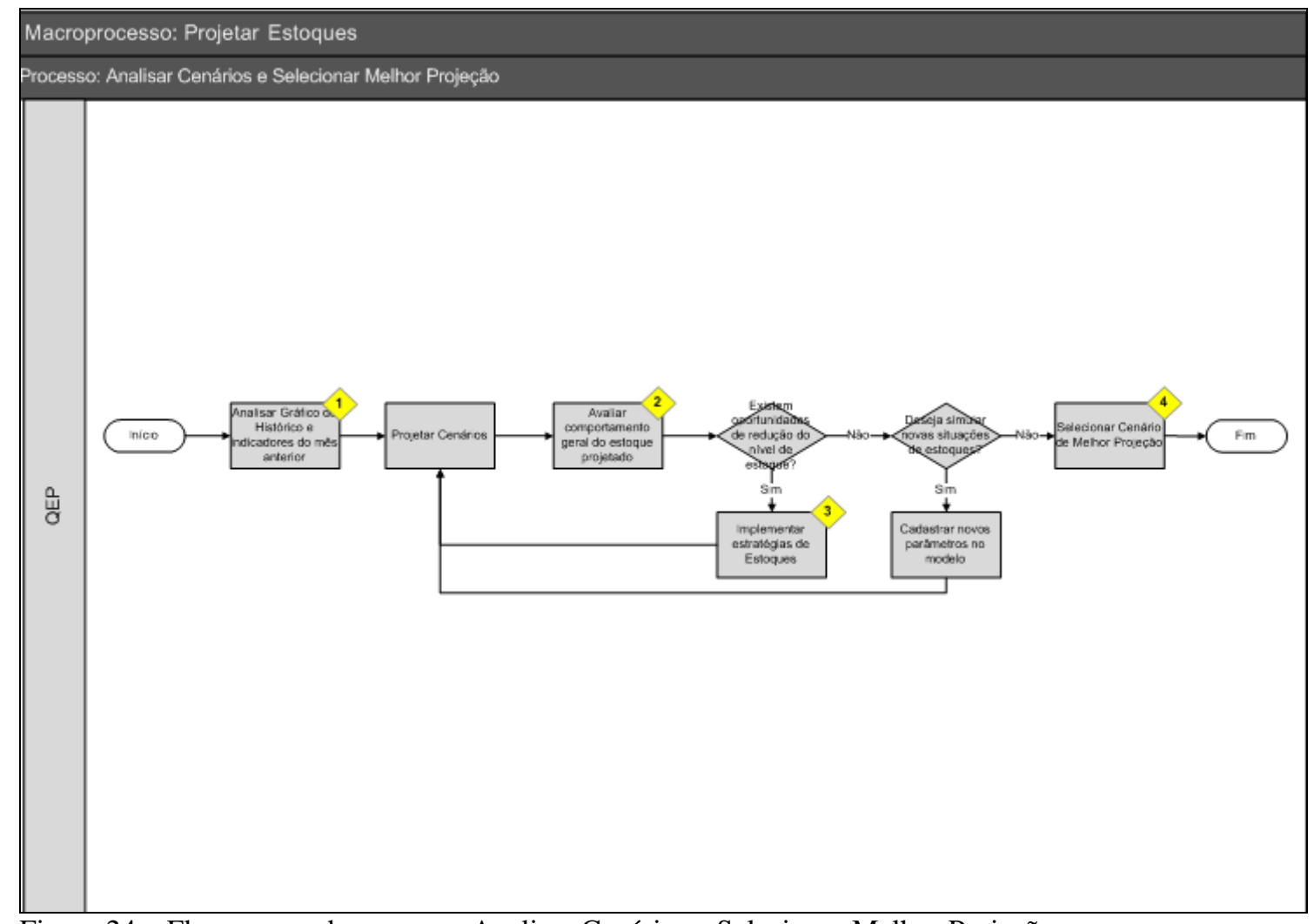

Figura 24 - Fluxograma do processo Analisar Cenários e Selecionar Melhor Projeção Fonte: O autor, (2012).

A gerência de Qualidade e Estoque de Produtos (QEP) deverá analisar o comportamento histórico dos estoques e dos seus indicadores, de forma a definir os cenários de projeção. O gráfico histórico se baseia nos dados históricos oriundos do macroprocesso Coletar Informações e os indicadores são oriundos do macroprocesso Analisar Indicadores de Desempenho, que será detalhado logo em seguida.

A segunda atividade do processo se dá através do preenchimento dos dados de projeção da produção, qualidade, tancagem, lastro e offloading, realizados nas etapas anteriores, mas que deverão ser repetidos aqui nesta etapa para projetar diferentes cenários. Deverão ser definidos cenários pessimistas, realistas ou otimistas, baseado no comportamento histórico da plataforma ou de acordo com as perspectivas futuras, através de dados determinísticos imputados no sistema. Deverão ser simulados diferentes cenários, podendo inclusive ser feita análise de risco para cada cenário. E a cada nova projeção, os dados de entrada no sistema podem ser alterados e comparados com os demais cenários criados. A partir daí, a gerência de Qualidade e Estoque de Produtos (QEP) deve analisar cada projeção, 
como no exemplo do Gráfico 8, gerado automaticamente pelo sistema SIGEP, e que apresenta as projeções de estoque de óleo, de acordo com os teores (\%) de BSW, e de água, além das variações na capacidade de tancagem, lastro, produção e as retiradas de petróleo para o período projetado. Além do gráfico, é gerada uma tabela com os dados projetados, que serão utilizados para criação do gráfico, conforme apresentado através da Tabela 27.

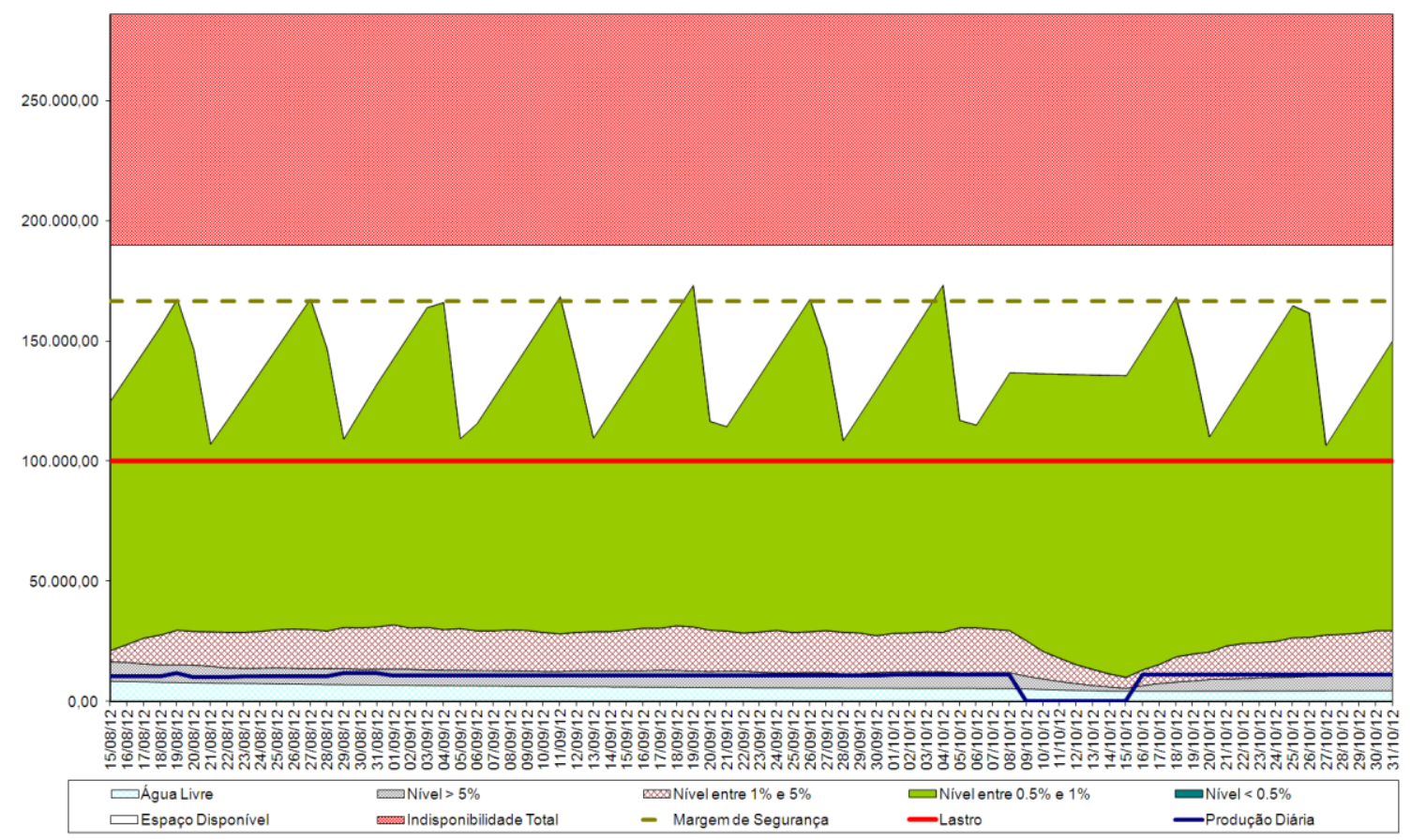

Gráfico 8 - Exemplo Fictício de Projeção de Estoques Fonte: O autor, (2012).

A partir desta análise, deverão ser identificadas melhorias que podem ser inseridas no modelo para melhor representar a projeção dos estoques da plataforma, além de ações junto aos gestores das áreas de qualidade, tancagem e transferência das unidades operacionais, de modo a atuar de forma preventiva na solução de possíveis futuros problemas.

Após a análise da projeção de estoques, deve-se avaliar a possibilidade de redução dos estoques, levando em consideração a estratégia da companhia, as restrições operacionais e os custos associados. Caso seja definida alguma estratégia, a mesma deve ser considerada em uma nova projeção de cenários e comparada com as demais. 
Tabela 27 - Exemplo Fictício de Projeção de Estoques

\begin{tabular}{|c|c|c|c|c|c|c|c|}
\hline Data & \begin{tabular}{|l|} 
Capacidade Projeto \\
\end{tabular} & \begin{tabular}{|l} 
Indisponibilidade Permanente \\
\end{tabular} & Indisponibilidade Variável & Capacidade Operacional & Margem de Segurança & \begin{tabular}{|l|} 
Espaço Disponivel \\
\end{tabular} & Lastro \\
\hline $15 / 8 / 2012$ & 286.000 & 0 & -96.000 & 190.000 & 21.172 & 64.807 & 100.000 \\
\hline $16 / 8 / 2012$ & 286.000 & 0 & -96.000 & 190.000 & 21.172 & 54.526 & 100.000 \\
\hline $17 / 8 / 2012$ & 286.000 & 0 & -96.000 & 190.000 & 21.172 & 44.240 & 100.000 \\
\hline $18 / 8 / 2012$ & 286.000 & 0 & -96.000 & 190.000 & 21.172 & 33.951 & 100.000 \\
\hline $19 / 8 / 2012$ & 286.000 & 0 & -96.000 & 190.000 & 23.484 & 22.502 & 100.000 \\
\hline $20 / 8 / 2012$ & 286.000 & 0 & -96.000 & 190.000 & 20.235 & 43.474 & 100.000 \\
\hline $21 / 8 / 2012$ & 286.000 & 0 & -96.000 & 190.000 & 20.235 & 82.841 & 100.000 \\
\hline $22 / 8 / 2012$ & 286.000 & 0 & -96.000 & 190.000 & 20.235 & 73.005 & 100.000 \\
\hline $23 / 8 / 2012$ & 286.000 & 0 & -96.000 & 190.000 & 20.768 & 62.899 & 100.000 \\
\hline $24 / 8 / 2012$ & 286.000 & 0 & -96.000 & 190.000 & 20.768 & 52.790 & 100.000 \\
\hline $25 / 8 / 2012$ & 286.000 & 0 & -96.000 & 190.000 & 20.768 & 42.677 & 100.000 \\
\hline $26 / 8 / 2012$ & 286.000 & 0 & -96.000 & 190.000 & 20.768 & 32.561 & 100.000 \\
\hline $27 / 8 / 2012$ & 286.000 & 0 & -96.000 & 190.000 & 20.768 & 22.442 & 100.000 \\
\hline $28 / 8 / 2012$ & 286.000 & 0 & -96.000 & 190.000 & 20.768 & 43.120 & 100.000 \\
\hline $29 / 8 / 2012$ & 286.000 & 0 & -96.000 & 190.000 & 23.484 & 80.734 & 100.000 \\
\hline $30 / 8 / 2012$ & 286.000 & 0 & -96.000 & 190.000 & 23.484 & 69.250 & 100.000 \\
\hline $31 / 8 / 2012$ & 286.000 & 0 & -96.000 & 190.000 & 23.484 & 57.764 & 100.000 \\
\hline \begin{tabular}{|l|} 
Produção Diária \\
\end{tabular} & BSW $<0.5 \%$ & BSW entre $0.5 \%$ e $1 \%$ & BSW entre $1 \%$ e $5 \%$ & BSW $>5 \%$ & Água Livre & Estoque Total & \begin{tabular}{|l} 
Lote Retirada \\
\end{tabular} \\
\hline $10.586,20$ & 0 & 103.927 & 4.591 & 8.148 & 8.527 & 125.193 & \\
\hline $10.586,20$ & 0 & 111.632 & 7.363 & 8.073 & 8.406 & 135.474 & \\
\hline $10.586,20$ & 0 & 119.316 & 10.720 & 7.434 & 8.290 & 145.760 & \\
\hline $10.586,20$ & 0 & 128.309 & 12.284 & 7.279 & 8.177 & 156.049 & \\
\hline $11.742,00$ & 0 & 137.805 & 14.217 & 7.387 & 8.088 & 167.498 & \\
\hline $10.117,50$ & 0 & 117.347 & 13.858 & 7.346 & 7.975 & 146.526 & 80.000 \\
\hline $10.117,50$ & 0 & 78.135 & 14.244 & 6.914 & 7.866 & 107.159 & \\
\hline $10.117,50$ & 0 & 88.131 & 14.707 & 6.396 & 7.760 & 116.995 & \\
\hline $10.384,00$ & 0 & 98.250 & 14.894 & 6.294 & 7.663 & 127.101 & \\
\hline $10.384,00$ & 0 & 108.003 & 15.193 & 6.444 & 7.569 & 137.210 & \\
\hline $10.384,00$ & 0 & 117.379 & 15.692 & 6.773 & 7.478 & 147.323 & \\
\hline $10.384,00$ & 0 & 127.235 & 16.241 & 6.572 & 7.391 & 157.439 & \\
\hline $10.384,00$ & 0 & 137.615 & 16.193 & 6.444 & 7.307 & 167.558 & \\
\hline $10.384,00$ & 0 & 117.519 & 15.516 & 6.620 & 7.225 & 146.880 & 80.000 \\
\hline $11.742,00$ & 0 & 78.412 & 17.060 & 6.626 & 7.169 & 109.266 & \\
\hline $11.742,00$ & 0 & 90.059 & 17.143 & 6.433 & 7.116 & 120.750 & \\
\hline $11.742,00$ & 0 & 101.137 & 17.506 & 6.529 & 7.064 & 132.236 & \\
\hline
\end{tabular}

Fonte: O autor, (2012).

Para cada cenário, deverão ser efetuadas projeções para cada porte de navio disponível na frota atual da empresa, de modo a identificar o tipo de navio que minimiza os custos totais das operações, considerando os custos de oportunidade do óleo armazenado e os custos de transporte de cada navio para o horizonte de tempo previsto. A partir da escolha do tipo de navio, o lote ideal para transferência é definido automaticamente, de acordo com a capacidade de armazenagem do navio selecionado.

Através da Tabela 28, é apresentado um exemplo, com dados fictícios, da análise comparativa dos custos totais das operações, considerando os diferentes cenários de projeção. Um dos cenários foi parametrizado para escoamento de petróleo utilizando navios com capacidade de $80.000 \mathrm{~m} 3$ enquanto o outro cenário considerou navios com porte de $40.000 \mathrm{~m} 3$. Na prática, serão efetuadas análises considerando todos os portes de navio, de diferentes capacidades, disponíveis na frota da empresa.

Para cada cenário, foram calculados os custos de transporte ao longo do período projetado, multiplicando-se o custo unitário de transporte (US $\$ / \mathrm{m} 3$ ) de cada tipo de navio pelo volume previsto (m3) de transferência para cada mês projetado. 
Da mesma forma, foram calculados os custos de oportunidade do óleo armazenado na plataforma, considerando apenas o estoque de óleo em condições de ser vendido, ou seja, dentro das especificações de qualidade e que esteja disponível para ser transferido, isto é, não pode estar sendo utilizado como lastro. O cálculo é feito considerando o custo médio mensal do estoque (US\$), que é resultado do estoque médio mensal (m3) multiplicado pelo preço de mercado do óleo armazenado na plataforma (US\$/m3). Em seguida, aplica-se a taxa mínima de atratividade (TMA) dos projetos da companhia para calcular o seu custo de oportunidade.

O custo total será a soma do custo de oportunidade do estoque e do custo de transporte e o melhor cenário será aquele que obtiver como resultado o menor custo total. No exemplo descrito abaixo, o melhor cenário corresponde ao escoamento com navios com capacidade de $80.000 \mathrm{~m} 3$.

Tabela 28 - Exemplo (dados fictícios) de Análise Comparativa dos Custos Totais de Diferentes Cenários de Projeção

\begin{tabular}{|c|c|c|c|c|c|c|c|}
\hline Capacidade de Armazenagem do Navio & $80.000 \mathrm{m3}$ & & & Capacidade de Armazenagem do Navio & $40.000 \mathrm{m3}$ & & \\
\hline Custos & $8 / 2012$ & $9 / 2012$ & $10 / 2012$ & Custos & $8 / 2012$ & 9/2012 & $10 / 2012$ \\
\hline Custo Médio de Estoque (US\$) & 2.249 .717 & 2.274 .090 & 2.271 .441 & Custo Médio de Estoque (US\$) & 1.934 .550 & 1.916 .842 & 1.841 .326 \\
\hline Custo de oportunidade de Estoque (US\$) & 19.123 & 19.330 & 19.307 & Custo de oportunidade de Estoque (US\$) & 16.444 & 16.293 & 15.651 \\
\hline Custo de Transporte (US\$) & 1.907 .498 & 3.817 .489 & 2.863 .117 & Custo de Transporte (US\$) & 2.482 .374 & 4.964 .749 & 4.288 .302 \\
\hline Custo Total (US\$) & 1.926 .620 & 3.836 .819 & 2.882 .424 & Custo Total (US\$) & 2.498 .818 & 4.981 .042 & 4.303 .953 \\
\hline
\end{tabular}

Fonte: $\mathrm{O}$ autor, (2012).

\subsection{3}

\section{Controlar Estoques}

A terceira etapa do processo de gestão de estoques consiste em acompanhar e registrar diariamente a produção, os estoques e a qualidade do óleo produzido e armazenado; a disponibilidade e a utilização da tancagem; as operações de transferência; e as projeções diárias com horizonte de sete dias, de modo a minimizar os eventos indesejáveis de parada de produção por falta de escoamento e entrega de óleo fora da especificação e / ou água para os terminais e refinarias da companhia ou para os clientes externos (exportação), bem como identificar oportunidades de redução de custos operacionais.

Vale ressaltar que o controle de processo, que determina ações estritamente operacionais como, por exemplo, controle de temperatura e pressão, é uma atividade que é e continuará sendo efetuada pelas áreas operacionais. 
Portanto, o acompanhamento das variáveis citadas no parágrafo anterior deverá ser realizado com atualização diária e não em tempo real, e qualquer interpretação dos dados deverá ter suas conclusões validadas com as unidades operacionais antes de qualquer tomada de decisão.

Através da Figura 25 é apresentado o detalhamento do macroprocesso Controlar Estoques, indicando o processo que o compõe. Em seguida, é descrito o detalhamento deste processo e o fluxograma das suas atividades.

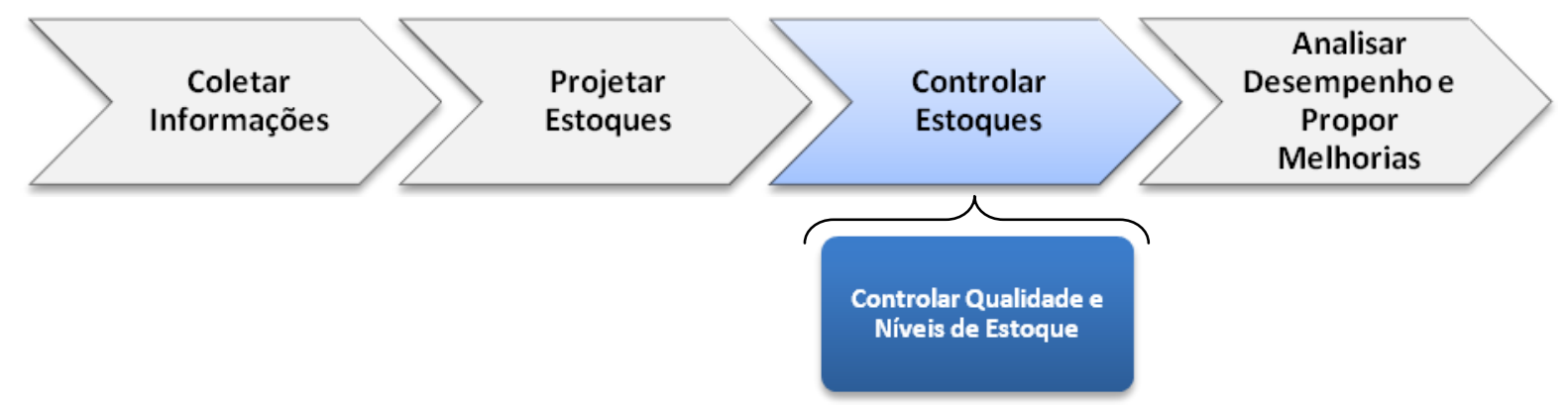

Figura 25 - Detalhamento do Macroprocesso Controlar Estoques

Fonte: O autor, (2012).

O registro diário das informações necessárias ao acompanhamento do processo é efetuado através do preenchimento do boletim PRP (Planejamento da Retirada de Petróleo), pelos profissionais embarcados nas plataformas. Como o respectivo fluxo de informações já foi apresentado no capítulo 4.2.1. Coletar Informações, serão apresentadas neste capítulo apenas as atividades relacionadas ao acompanhamento destas variáveis.

Através da Figura 26 é apresentado o fluxograma das atividades do processo Controlar Qualidade e Níveis de Estoque. 


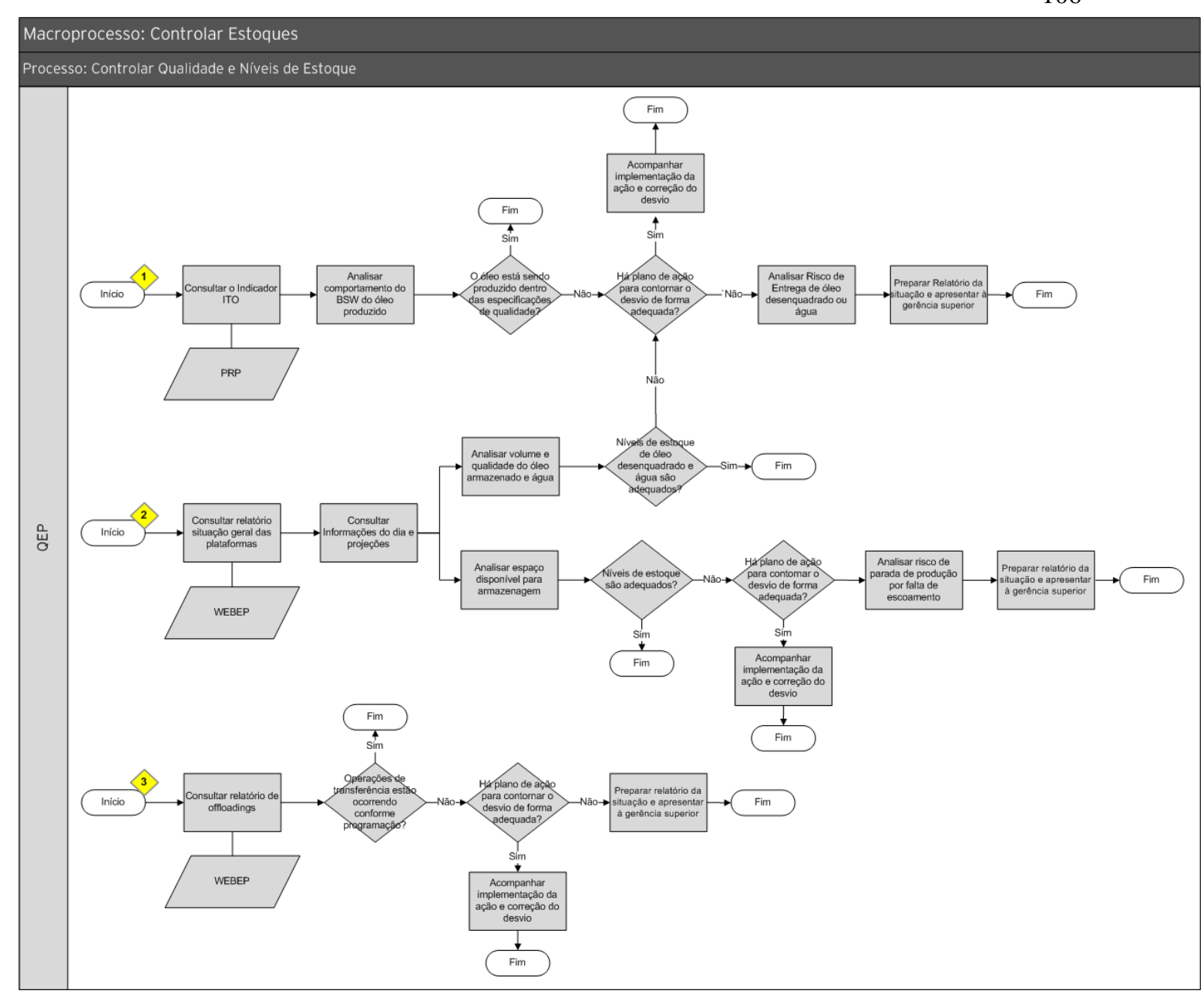

Figura 26 - Fluxograma do processo Controlar Qualidade e Níveis de Estoque Fonte: O autor, (2012).

As equipes que trabalham nesta atividade devem ser responsáveis por um grupo de plataformas, de modo a adquirir conhecimento e experiência à respeito dos seus sistemas de processamento, armazenagem e escoamento.

A gerência de Qualidade e Estoque de Produtos (QEP) deverá acompanhar a qualidade do petróleo produzido através do item de controle denominado ITO (índice de tratamento do óleo), através de consulta ao boletim BDP (boletim de produção). Este item de controle é atualmente acompanhado pelas plataformas, mas deverá ser acompanhado corporativamente. O ITO corresponde ao BSW medido após o petróleo ser processado na planta de tratamento, onde é feita a separação da água e do óleo produzidos. O acompanhamento será feito diariamente, baseado no BSW médio diário, conforme apresentado através do Gráfico 9. 
Caso o BSW da produção esteja fora da especificação requerida, deve-se entrar em contato com a unidade operacional, de modo a identificar as causas dos desvios e verificar se há plano de ação para contorná-lo de forma adequada, evitando a entrega de óleo desenquadrado (considerado produto semi-acabado) e/ou água para os terminais e refinarias. Caso não haja plano de ação em andamento ou o mesmo não garanta a solução do problema, deve-se analisar o risco da entrega de óleo fora da especificação e /ou água, preparar relatório da situação e apresentar à gerência superior, para que ações emergenciais sejam providenciadas.

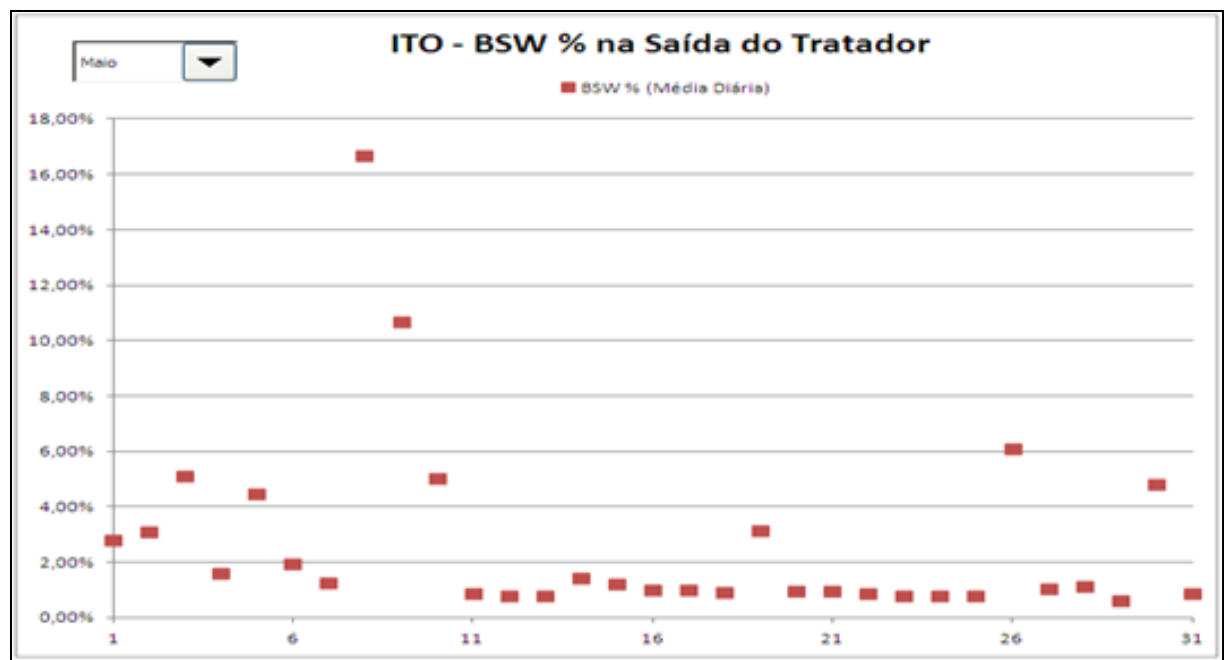

Gráfico 9 - Exemplo (fictício) de acompanhamento do BSW produzido por uma plataforma Fonte: O autor, (2012).

Deve-se acompanhar a qualidade do petróleo armazenado e a água, bem como a sua projeção para os sete dias seguintes, de forma a analisar se os volumes de óleo fora da especificação e a água estão em níveis adequados ou se há riscos da necessidade de sua entrega aos terminais e refinarias. Da mesma maneira, deve-se analisar o espaço disponível para armazenar a produção, com o objetivo de identificar se há riscos de parada de produção por falta espaço para armazenagem. Em ambos os casos, as unidades operacionais devem ser consultadas, de modo a obter informações à respeito da sua situação operacional e do andamento das ações necessárias para eliminação dos desvios. Caso não haja plano de ação em andamento ou o mesmo não garanta a solução do problema, os riscos devem ser analisados, de modo a subsidiar um relatório da situação a ser apresentado à gerência superior, para que ações emergenciais sejam providenciadas. 
Este acompanhamento deverá ser efetuado diariamente através do relatório Situação Geral das Plataformas (Figura 27), que foi desenvolvido no sistema WEBEP e apresenta a qualidade e o estoque do óleo armazenado, por plataforma, (gráfico Geral das Plataformas) e a projeção da qualidade para os sete dias seguintes (gráfico Estoque Previsto).

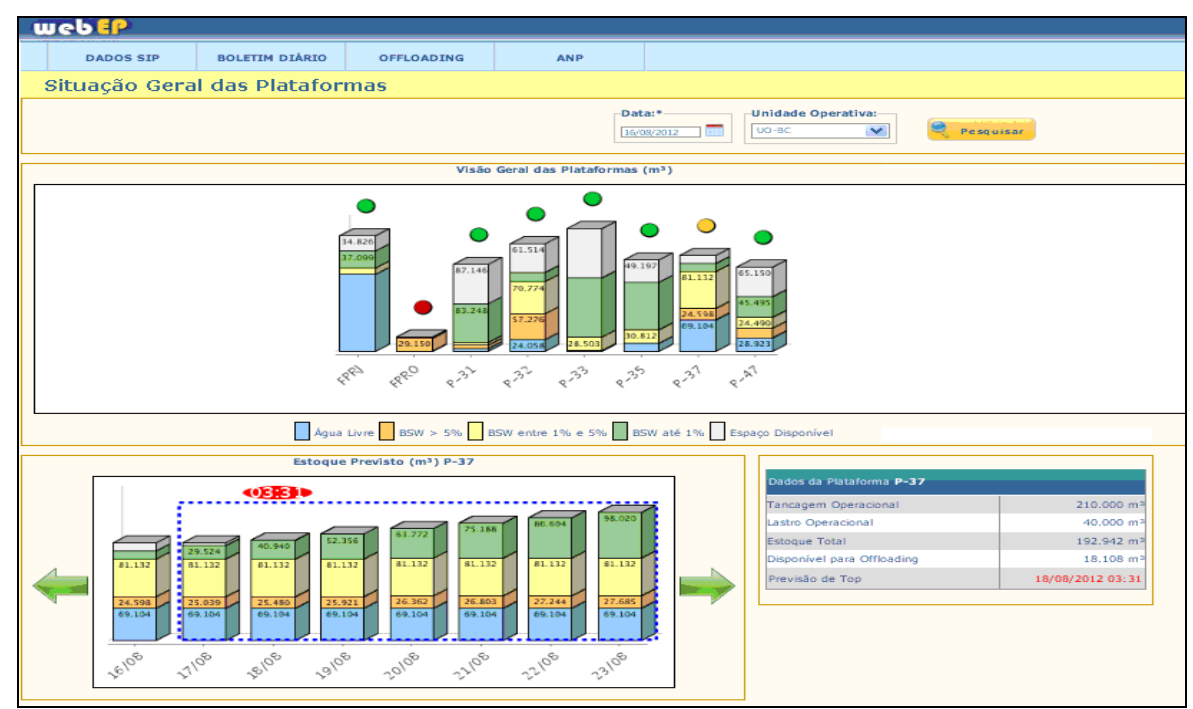

Figura 27 - Exemplo (fictício) de consulta do relatório Situação Geral das Plataformas Fonte: O autor, (2012).

Ao selecionar a data e a unidade operacional, é apresentada, através de um gráfico de barras (gráfico Visão Geral das Plataformas), a utilização da tancagem de todas as plataformas desta unidade, através da composição dos seus estoques, de acordo com cada fluido, e o espaço disponível para armazenagem da produção, que corresponde à parte cinza da barra. Acima de cada barra há um círculo que sinaliza a condição da plataforma do ponto de vista do risco de parada de produção por falta de espaço para sua armazenagem. O círculo verde sinaliza que há capacidade de armazenagem para mais de dois dias de produção, enquanto a cor amarela sinaliza que há capacidade para apenas dois de produção e o círculo vermelho sinaliza que há capacidade para apenas um dia de produção. Ao selecionar a barra correspondente a uma das plataformas, o relatório apresenta outro gráfico de barras (gráfico Estoque Previsto) com a previsão de data e hora do top de produção (em vermelho), que significa o momento em que não haverá mais espaço disponível para armazenar a produção. 
Para acompanhar diariamente as operações de transferência, será necessário consultar o relatório de offloadings, desenvolvido também no sistema WEBEP, de acordo com a Figura 28, onde são registrados dados operacionais como data e hora da chegada e saída do navio, data e hora do início e fim da operação, volume programado, volume transferido até o momento, qualidade do óleo, vazão de bombeio, status da operação (se houve interrupção, se está em andamento, etc.), disponibilidade das estações de offloading, bem como outras informações. Devese analisar se as operações estão ocorrendo conforme a programação. Caso sejam detectados desvios, deve-se verificar junto à unidade operacional se a situação já foi resolvida ou se há ações em andamento para a sua solução. Caso não haja plano de ação em andamento ou o mesmo não garanta a solução do problema, deve-se preparar um relatório da situação e apresentar à gerência superior, para que ações emergenciais sejam providenciadas.

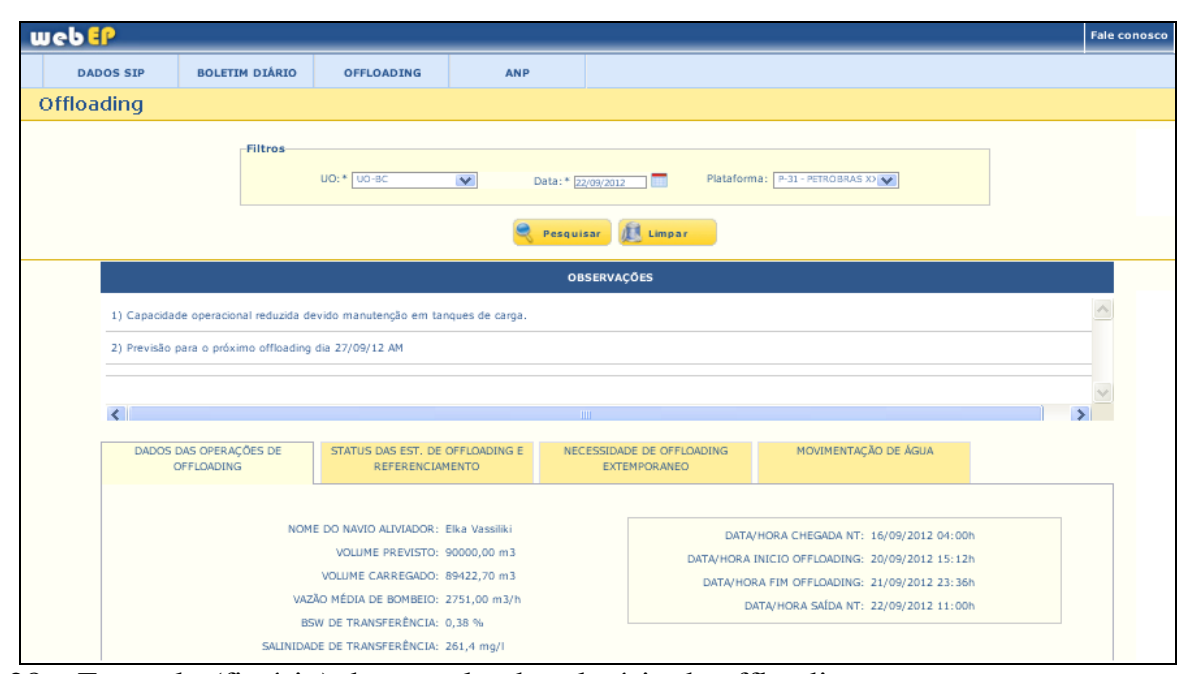

Figura 28 - Exemplo (fictício) de consulta do relatório de offloading Fonte: O autor, (2012).

\subsection{4}

\section{Analisar Desempenho e Propor Melhorias}

A quarta e última etapa do processo de gestão de estoques consiste em analisar o desempenho das operações e propor melhorias. Os indicadores de desempenho devem ser capazes de apontar desvios entre as projeções e as realizações. Após sua apuração mensal, deverão ser realizadas reuniões de análise 
crítica do processo com todos os envolvidos, levando em consideração tanto os indicadores quanto o comportamento histórico das plataformas, de modo a identificar as causas dos desvios e as oportunidades de melhoria, e propor ações para as causas e oportunidades identificadas no processo como um todo.

Ao final desta etapa, deve-se elaborar um plano de ação, identificando responsáveis e prazos, e que deverá ser acompanhado mensalmente através da reunião de análise crítica.

Através da Figura 29 é apresentado o detalhamento do macroprocesso Analisar Desempenho e Propor Melhorias, indicando os processos que o compõem. Em seguida, é descrito o detalhamento destes processos e o fluxograma das suas atividades.

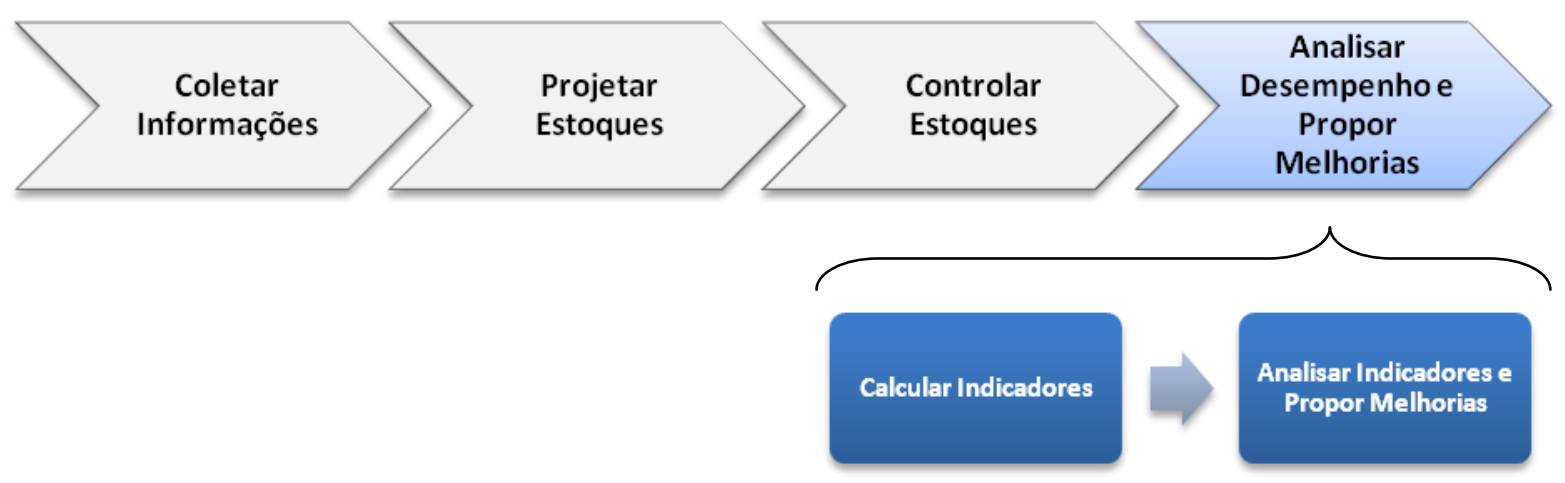

Figura 29 - Detalhamento do Macroprocesso Analisar Desempenho e Propor Melhorias Fonte: O autor, (2012).

\subsubsection{1}

Calcular Indicadores

Através da Figura 30 é apresentado o fluxograma das atividades do processo Calcular Indicadores.

A gerência de Qualidade e Estoque de Produtos deverá coletar e organizar as informações relacionadas às operações realizadas e consolidá-las numa planilha em formato Excel. Segue abaixo a relação das informações realizadas que deverão ser coletadas e a respectiva fonte de dados. 
- BSW do óleo produzido: relatório ITO (índice de tratamento do óleo - fonte: boletim BDP - boletim de produção);

- Distribuição da qualidade do óleo armazenado em estoque: boletim PRP (planejamento da retirada de petróleo);

- Utilização da capacidade operacional: boletim PRP (planejamento da retirada de petróleo);

- Duração das operações de offloading: boletim BQP (boletim de qualidade do petróleo);

- Volume de óleo disponível ao longo do mês: boletim PRP (planejamento da retirada de petróleo);

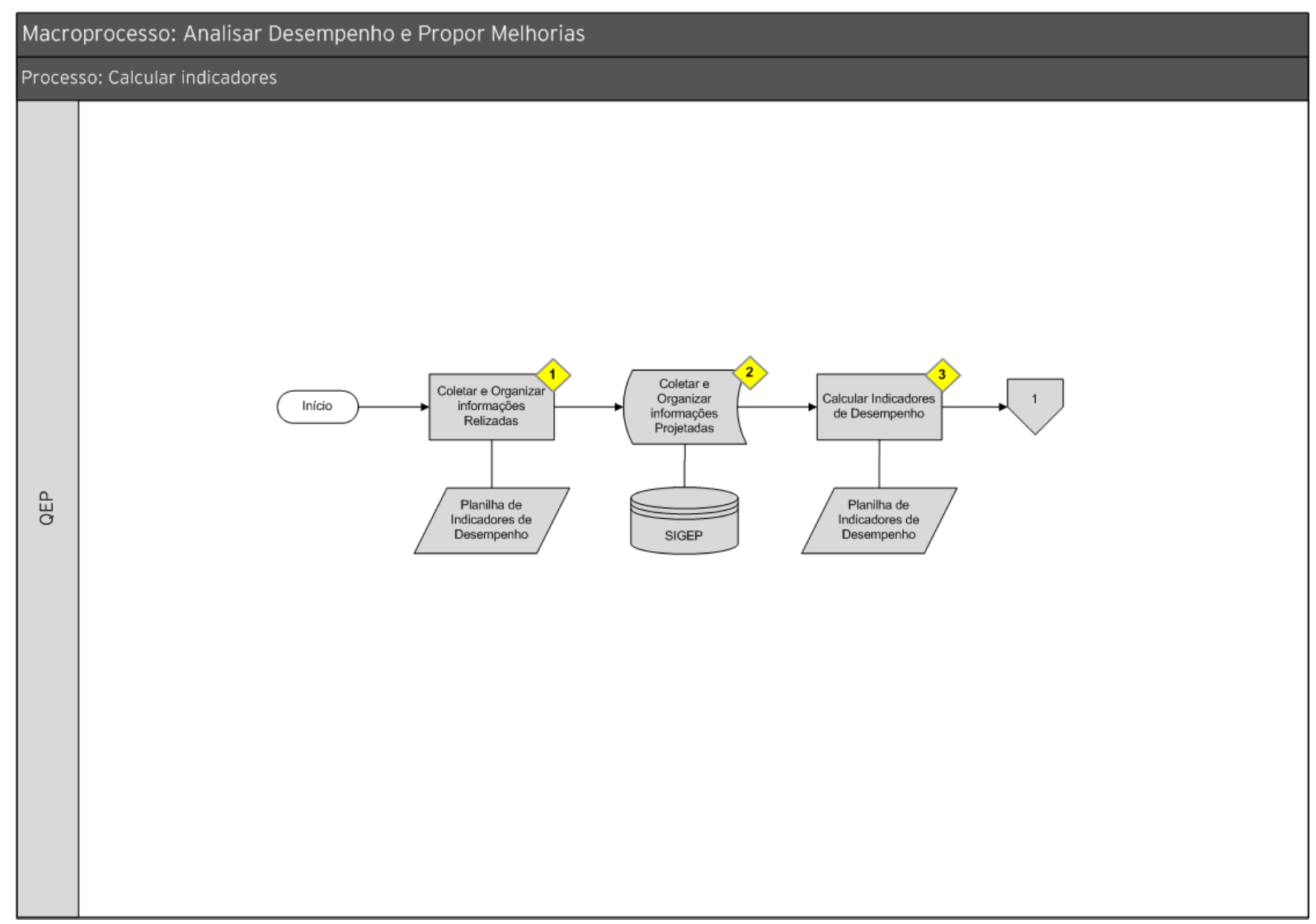

Figura 30 - Fluxograma do processo Calcular Indicadores Fonte: O autor, (2012).

Deve-se coletar e organizar as informações relacionadas às projeções de estoques, efetuadas na etapa de projeção de estoques, conforme descrito no capítulo 4.2.3.1. (Analisar Cenários e Selecionar Melhor Projeção). 
A seguir são detalhados os indicadores de desempenho, seus objetivos e a respectiva fórmula de cálculo.

\section{Índice de Tratamento de Óleo:}

\section{Objetivos:}

- indicar tendências do comportamento da qualidade do óleo produzido;

- efetuar correlações com a qualidade do óleo armazenado;

- identificar necessidade de ações de melhoria no tratamento do óleo.

\section{Fórmula de Cálculo:}

- barras do gráfico: distribuição \% da produção por tipo de fluido

$=\underline{\text { número de dias de produção por tipo de fluido }} \times 100$ número de dias do mês

- linha vermelha do gráfico: BSW\% - média mensal

= $\underline{\text { somatório do BSW médio diário durante o mês }} \times 100$ número de dias do mês

É apresentado, através do Gráfico 10, um exemplo do índice de tratamento de óleo.

Gráfico 10 - Exemplo (fictício) do índice de tratamento de óleo

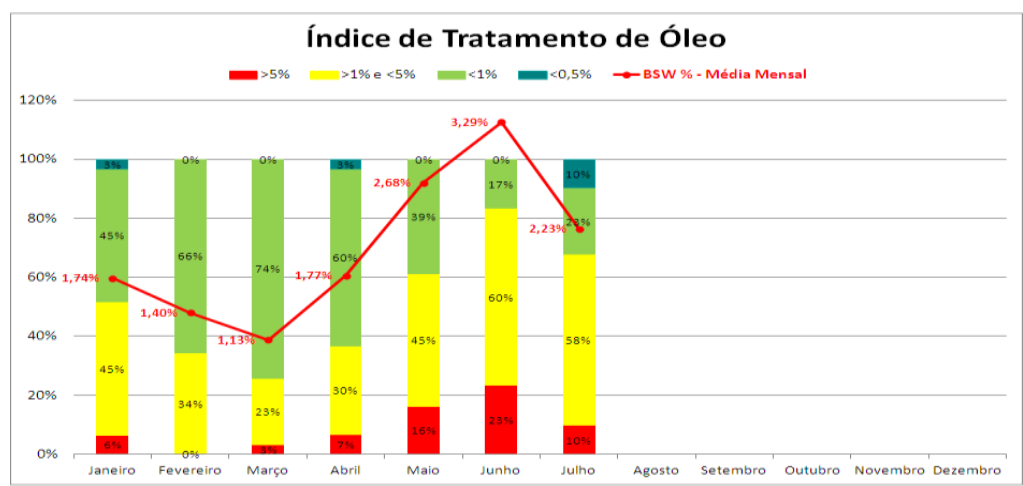
Fonte: O autor, (2012). 
Distribuição (\%) da Qualidade do Óleo em Estoque

\section{Objetivos:}

- indicar tendências no comportamento da qualidade do óleo armazenado;

- identificar risco qualitativo de entrega de óleo desenquadrado e/ou água para os terminais e refinarias;

- ajustar o modelo de previsão baseado na comparação com resultados projetados pela ferramenta de simulação.

Fórmula de Cálculo:

$=\underline{\text { estoque médio por tipo de fluido }} \times 100$

estoque total

É apresentado, através do Gráfico 11, um exemplo do indicador distribuição (\%) da qualidade do óleo em estoque.

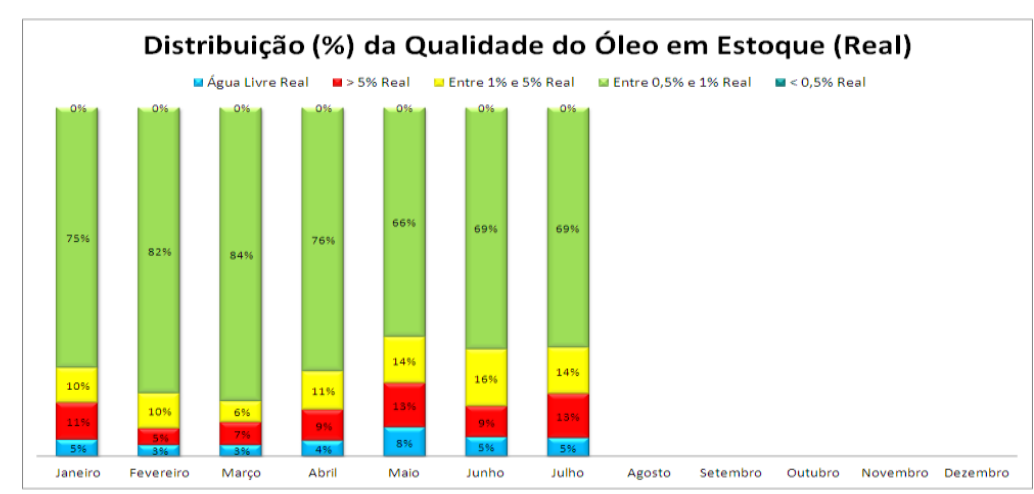

Gráfico 11 - Exemplo (fictício) do indicador distribuição (\%) da qualidade do óleo em estoque Fonte: $\mathrm{O}$ autor, (2012).

\section{Fator de Utilização da Capacidade Operacional}

\section{Objetivos:}

- Analisar a utilização da tancagem operacional de forma quantitativa;

- Identificar risco qualitativo de top de produção ou ineficiências operacionais no offloading, seja por retirada de lotes menores ou offloadings demorados. As 
causas podem ser qualidade do óleo, indisponibilidade dos sistemas de offloading ou condições de mar adversas;

- Analisar as causas das ineficiências;

- Identificar necessidade de ações de melhoria da utilização da capacidade operacional.

\section{Fórmula de Cálculo:}

$=$ estoque médio - lastro médio x 100

capacidade operacional - lastro médio - margem de segurança

É apresentado, através do Gráfico 12, um exemplo do indicador fator de utilização da capacidade operacional.

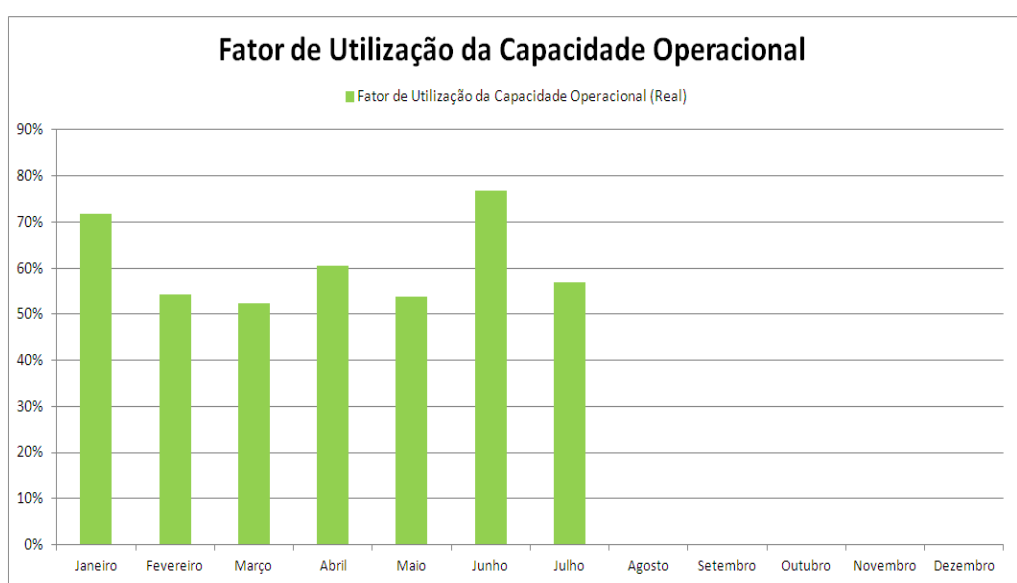

Gráfico 12 - Exemplo (fictício) do indicador fator de utilização da capacidade operacional Fonte: O autor, (2012).

\section{Duração Média de Offloading}

\section{Objetivos:}

- Analisar a duração média dos offloadings com foco na redução dos custos de sobrestadia (=tempo que ultrapassa 36 horas de operação);

- Analisar as causas dos atrasos nas operações de offloading;

- Identificar necessidade de ações de melhoria para redução dos custos de sobrestadia. 
Fórmula de Cálculo:

$=\underline{\text { soma dos tempos de duração dos offloadings ocorridos no mês }}$

número de operações de offloading ocorridas no mês

É apresentado, através do Gráfico 13, um exemplo do indicador duração média de offloading.

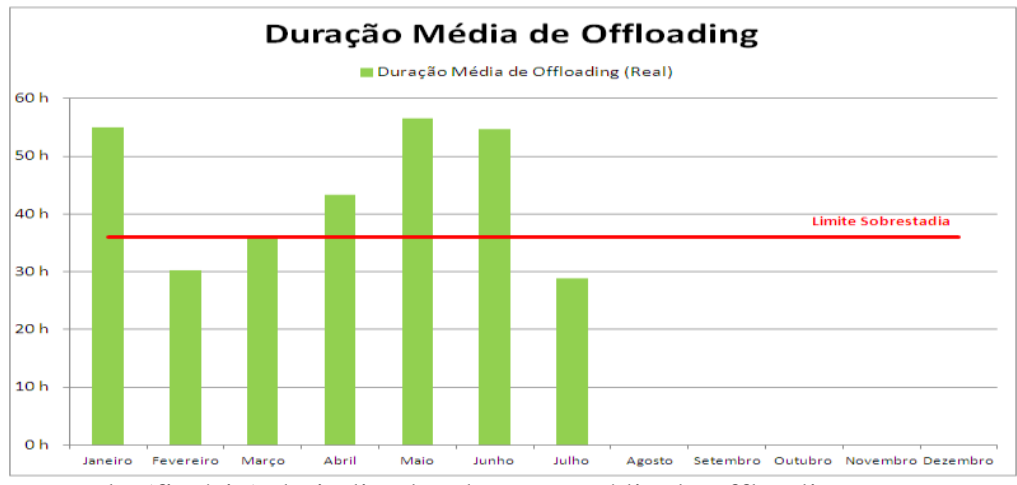

Gráfico 13 - Exemplo (fictício) do indicador duração média de offloading Fonte: $\mathrm{O}$ autor, (2012).

Índice de Previsão de Óleo Disponível

\section{Objetivos:}

- Analisar o processo de previsão dos estoques;

- Analisar as causas das divergências;

- Ajustar o modelo ou melhorar a qualidade das informações de entrada no simulador.

\section{Fórmula de Cálculo:}

$=\underline{\text { volume médio de óleo disponível para offloading (previsto) }}$

volume médio de óleo disponível para offloading (real)

É apresentado, através do Gráfico 14, um exemplo do índice de previsão de óleo disponível. 


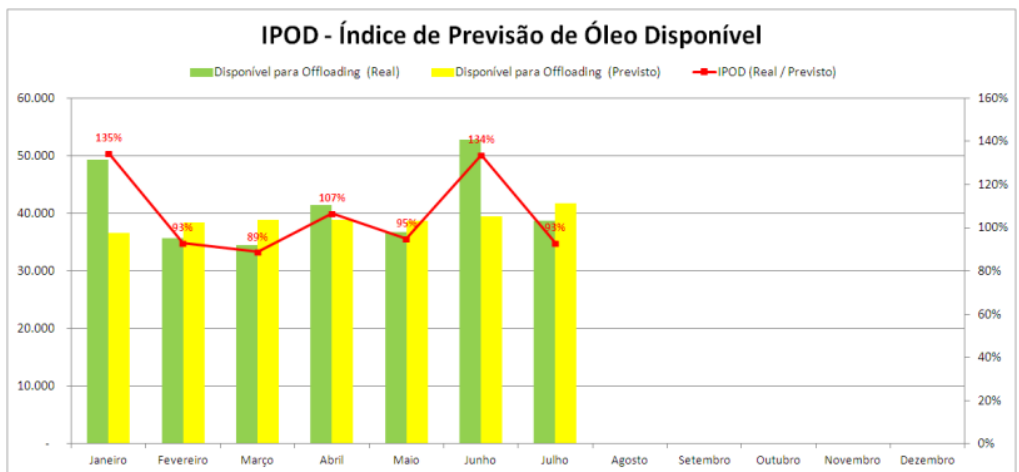

Gráfico 14 - Exemplo (fictício) do índice de previsão de óleo disponível Fonte: O autor, (2012).

\subsubsection{2}

Analisar Indicadores e Propor Melhorias

Através da Figura 31 é apresentado o fluxograma das atividades do processo Analisar Indicadores e Propor Melhorias.

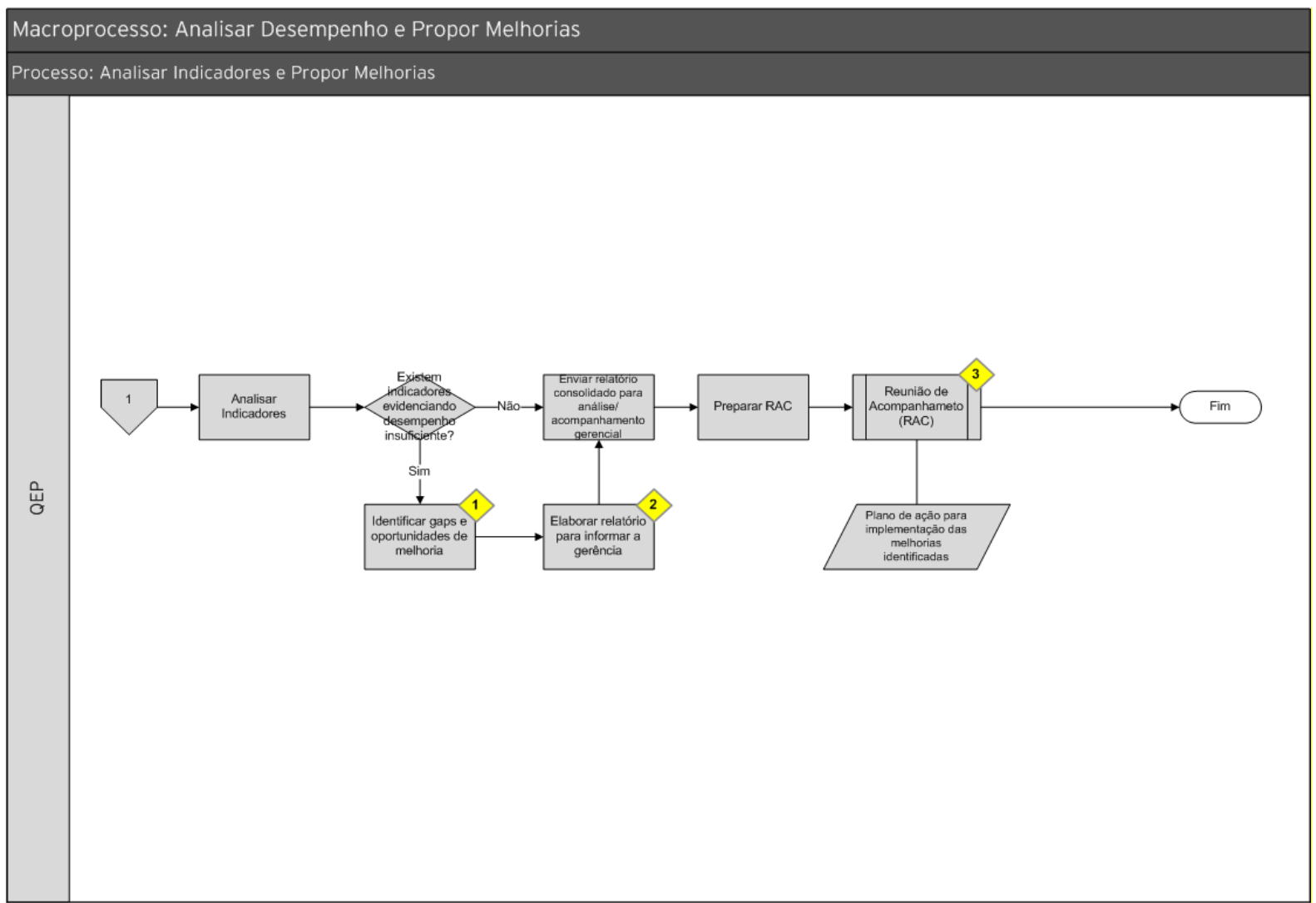

Figura 31 - Fluxograma do processo Analisar Indicadores e Propor Melhorias Fonte: O autor, (2012).

Este processo deverá ocorrer com periodicidade mensal e tem como principal objetivo identificar as causas dos desvios e as oportunidades de melhoria 
e propor ações para as causas e oportunidades identificadas no processo de gestão de estoques como um todo.

A gerência de Qualidade e Estoque de Produtos (QEP) deverá efetuar a análise dos indicadores apurados na etapa anterior. Caso haja algum indicador com resultado abaixo do esperado, devem ser identificados os seus gaps e oportunidades de melhoria. Neste momento, deve haver muita interação com a unidade operacional, de modo a identificar as causas dos desvios e ações que já estejam em andamento.

Em seguida deverá ser elaborado um relatório resumido para avaliação gerencial, contendo os resultados dos indicadores, principais desvios, análises das causas dos desvios, oportunidades de melhoria e ações em andamento, com respectivos responsáveis e prazos.

Posteriormente, deverá ser realizada uma reunião de análise crítica, com participação gerencial e das unidades operacionais, onde será apresentado o conteúdo do relatório e o andamento das ações pendentes da reunião do mês anterior. As unidades operacionais deverão justificar os desvios, caso haja necessidade, e o andamento das ações pendentes, se houver. Após discussão e análise dos desvios e das ações em andamento, o corpo gerencial, em conjunto com as áreas envolvidas, poderá definir novas ações e indicar os responsáveis e prazos para a sua implantação. O produto final desta etapa é um plano de ações consolidado, contendo as ações pendentes da reunião anterior e as novas ações definidas nesta reunião. 


\section{Conclusões e Oportunidades de Pesquisas Futuras}

\section{1}

\section{Conclusões}

O grande mérito deste trabalho foi estruturar, de forma organizada, o encadeamento das atividades que são efetuadas rotineiramente pelos profissionais envolvidos, de uma forma ou de outra, porém de maneira empírica, sem embasamento teórico. Este trabalho tentou conciliar o referencial teórico com as práticas operacionais, com o objetivo de garantir que o mesmo reflita a realidade operacional, possa ser implantado em todas as plataformas e que venha trazer benefícios práticos para a organização.

Este trabalho mostrou que, do ponto de vista estratégico, a estruturação do processo de gestão de estoques em unidades marítimas de armazenagem e escoamento de petróleo dará subsídios aos administradores da organização para a tomada de decisões quanto ao planejamento dos seus níveis de estoque. Através da simulação de diferentes cenários e a projeção dos estoques para cada um deles, será possível determinar aquele que visa melhor atender aos objetivos da companhia. No entanto, para que o resultado seja potencializado, será necessária uma maior integração entre o novo processo apresentado neste trabalho e o processo atual de planejamento dos estoques realizado pela área de Logística, de modo a identificar os impactos dos cenários projetados em toda a cadeia de suprimento de petróleo da empresa.

Do ponto de vista tático, a melhoria da previsibilidade dos estoques de óleo disponíveis para escoamento possibilitará uma redução dos estoques de segurança nos terminais e refinarias, bem como trará maior confiabilidade à tomada de decisão quanto ao planejamento da alocação do melhor mix de petróleos para cada refinaria, cujo foco está na otimização do rendimento dos derivados, da mesma forma que para o planejamento das importações e exportações, cujo foco é a rentabilidade nas negociações comerciais. Além disso, dará suporte para um melhor dimensionamento e otimização da frota de navios 
aliviadores da produção, já que será possível identificar o tipo de navio que minimiza os custos totais, considerando os custos de oportunidade do óleo armazenado e os custos de transporte de cada navio.

Com relação ao aspecto operacional, podemos citar uma série de benefícios. A previsão de curtíssimo prazo (7 dias) da disponibilidade do óleo e dos sistemas de escoamento vem auxiliando o processo de programação dos navios para retirada de petróleo, porém ainda não foram medidos seus impactos nos custos de transporte. A previsão da utilização da tancagem permitirá o monitoramento e a garantia da continuidade operacional da produção, prevendo a data limite para sua retirada e minimizando a sua probabilidade de ocorrência. Já a previsão de curtíssimo prazo da qualidade do óleo e dos volumes de água armazenados darão subsídios para programar ações de contingência no caso de situações indesejadas. Por outro lado, a previsão de dois meses apontará oportunidades de melhoria e ações poderão ser tomadas com antecedência caso sejam detectados riscos de parada de produção por falta de escoamento ou de entrega de óleo desenquadrado ou água para os terminais e refinarias. Ações também deverão ser orientadas para reduzir as variabilidades oriundas do processo produtivo.

Após a decisão da companhia quanto ao planejamento dos estoques, o processo aqui descrito permitirá acompanhar a sua realização, apontar os desvios entre o planejado e o realizado, identificar as suas causas e as oportunidades de melhoria nos seus processos operacionais, fechando o ciclo da melhoria contínua.

Para se iniciar o desenvolvimento do processo de gestão de estoques, primeiramente foi necessário entender como os processos operacionais de produção, armazenagem e escoamento, que influenciam diretamente a qualidade e os níveis de estoque do petróleo armazenado, ocorrem nas frentes de trabalho. Para tal, foi de fundamental importância o envolvimento dos técnicos e gestores destes processos desde o início do projeto, de modo a absorver as características e particularidades de cada um destes e dar robustez ao novo processo de gestão de estoques.

Através das entrevistas com os gestores e técnicos das áreas operacionais, foi possível identificar não somente as variáveis que influenciam os níveis de estoque e a qualidade do óleo armazenado, mas também como as mesmas se interrelacionam e a sua relação de causa e efeito, de modo a modelar o seu 
comportamento num futuro breve. Através desta modelagem, será possível incorporar as aleatoriedades dos processos, de maneira a desenvolver um simulador que seja capaz de capturar a natureza estocástica do processo e a sua complexidade, com o objetivo de prever os estoques e a qualidade do óleo com um grau de incerteza aceitável.

Por se tratar de um processo de gestão que necessita de dados e informações, cujo objetivo é subsidiar os profissionais envolvidos nos níveis estratégico, tático e operacional de tomada de decisões, foi necessário criar e implantar novos fluxos de informações, visto que grande parte das informações necessárias não estava disponível de forma estruturada. Sem este importante passo, não seria possível dar andamento à estruturação do processo.

É importante destacar que o simulador está em fase de definição dos métodos matemáticos que serão utilizados para melhor representar o comportamento da qualidade do óleo produzido e armazenado nas plataformas. A partir de então, pretende-se efetuar testes piloto com algumas plataformas de modo a implantar todas as etapas do processo de gestão de estoques e, em seguida, estendê-lo para as demais unidades operacionais e integrá-lo à área de Logística.

Por fim, o estudo aqui apresentado não esgota todas as possibilidades de melhoria nesta área, muito pelo contrário, se torna um marco na área de exploração e produção para que estudos semelhantes e complementares sejam realizados em prol da busca de maior integração entre as áreas de upstream e downstream da indústria do petróleo.

\section{2}

\section{Oportunidades de Pesquisas Futuras}

Durante o decorrer desta dissertação verificou-se que a Petrobras, por ser uma grande empresa integrada de energia, possui um amplo campo de oportunidades para novos estudos e aplicações de diversas soluções inovadoras encontradas na literatura acadêmica para problemas relacionados com a gestão de estoques e os seus desdobramentos. A seguir são listadas algumas oportunidades de pesquisas futuras: 
- adaptar o modelo de simulação para períodos a partir de um ano, permitindo assim a sua utilização com o objetivo de dimensionar a frota de navios aliviadores da produção;

- estender o modelo de simulação de estoques para que o mesmo atue, de forma integrada, em toda a cadeia de suprimentos do petróleo, desde a sua produção, passando pelo transporte, refino e a distribuição dos derivados;

- estender o processo aqui proposto ao processo atual efetuado para a área de Abastecimento-Logística da empresa, de forma a buscar ganhos de integração, apresentando novas formas de trabalho, com a utilização de ambientes colaborativos e sistemas de informação capazes de suportar tomadas de decisão baseadas em modelos matemáticos e de gestão de riscos, com o objetivo de melhorar a eficiência operacional e minimizar seus custos. 


\section{Referências Bibliográficas}

BALLOU, Ronald H. Logística empresarial: transportes, administração de materiais e distribuição física. São Paulo: Atlas, 1993.

BERTAGLIA, Paulo Roberto. Logística e gerenciamento da cadeia de abastecimento. São Paulo: Saraiva, 2005.

CHING, Hong Yuh. Gestão de estoques na cadeia de logística integrada: supply chain. 3 ed. São Paulo: Atlas, 2006.

CORONADO, O. Controladoria no atacado e varejo. São Paulo: Atlas, 2001.

DIAS, Marco Aurélio Pereira. Administração de materiais: uma abordagem logística. 3. ed. São Paulo 1993.

ELSAYED, E. A. Analysis and control of production systems. Englewood Cliffs, New Jersey: Prentice-Hall, 1985.

FRANCISCHINI, Paulino Graciano; GURGEL, Floriano do Amaral. Administração de materiais e do patrimônio. São Paulo: Pioneira Thomson Learning, 2002.

HANKE, J. E; REITSCH, A. G. Business forecasting. New Jersey: Prentice-Hall, 1998.

HARRIS, F. W. How many parts to make at once. Factory: the magazine of management; [S.1.], v. 10 no. 2, p. 135, Feb. 1913.

MESSIAS, S. B. Manual de administração de materiais: planejamento e controle de estoque. São Paulo: Atlas, 1993.

MOURA, C. E. Gestão de estoques. Rio de Janeiro: Ciência Moderna, 2004.

NADDOR, E. Inventory systems. New York: Wiley, 1966.

POZO, Hamilton. Administração de recursos materiais e patrimoniais: uma abordagem logística. 5. ed. São Paulo, 2008.

SANTORO, M. C. Sistema de gestão de estoque de múltiplos itens em local único. 2006. 109 f. Tese (Livre Docência em Gestão de Operações e Logística)Escola Politécnica, Universidade de São Paulo, São Paulo, 2006.

SILVER, E. A.; PIKE, D. F.; PETERSON, R. Inventoy management and production planning and scheduling. 3rd ed. New York: Wiley, 1998. 
SIMCHI-LEVI et al. Designing and managing the supply chain: concepts, strategies and case studies. New York: McGraw-Hill, 2003.

SLACK, Nigel et al. Administração da produção. São Paulo: Atlas, 1997.

TADEU, Hugo Ferreira Braga. Gestão de estoques: fundamentos, modelos matemáticos e melhores práticas aplicadas. São Paulo: Cengage Learning, 2011.

WANKE, P. Gestão de estoques na cadeia de suprimento. São Paulo: Editora Atlas, 2011. $176 \mathrm{p}$.

WINTERS, P. Forecasting sales by exponentialy weighted moving averages. Management Science, [S.1.], v. 6, p. 324-342, 1960. 